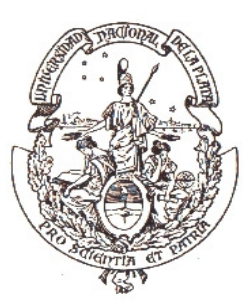

\author{
UNIVERSIDAD NACIONAL DE LA PLATA \\ Facultad de Ciencias Económicas \\ Escuela de Postgrado de Marketing Internacional
}

\title{
ANÁLISIS E IMPLEMENTACIÓN DE UN PLAN DE MARKETING ESTRATÉGICO EN LA INDUSTRIA DEL MOSAICO. CASO LA ESPAÑOLA.
}

Trabajo Científico Libre para la obtención del Grado de Magíster en Marketing Internacional.

Director de Tesis:

Prof. Ing. Enzo Campana
Presentado por:

Federico Del Giorgio Solfa

Calle 13 No 4689 esq. 488

(1897) M. B. Gonnet - La Plata

Fecha de entrega: 01/04/2002

Prohibida su divulgación: 3 años 


\section{ÍNDICE}

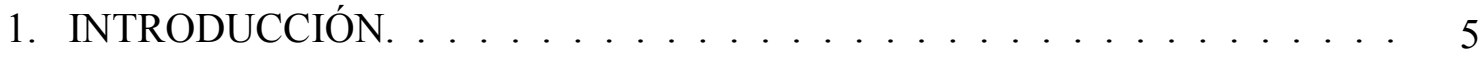

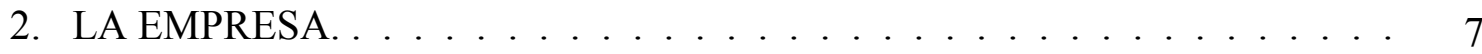

2.1. Antecedentes históricos y filosofía empresarial. . . . . . . . . . . . . . 7

2.2. Realidad actual de la empresa. . . . . . . . . . . . . . . . . . 9

2.3. Análisis comunicacional en publicidad. . . . . . . . . . . . . . 11

2.3.1. Guía telefónica. . . . . . . . . . . . . . . . 11

2.3.2. Revistas. . . . . . . . . . . . . . . . . 14

2.4. Análisis de la marca y logotipo de la empresa. . . . . . . . . . . . . . 15

2.5. Relevamiento de la atención telefónica. . . . . . . . . . . . 15

2.6. Análisis del punto de ventas. . . . . . . . . . . . . . . . . 17

3. ANÁLISIS DE LOS MERCADOS. . . . . . . . . . . . . . . . . . . 19

3.1. Mercado Masivo. . . . . . . . . . . . . . . . . . . . . . . . . . . . . . 19

3.2. Mercado Técnico. . . . . . . . . . . . . . . . . . . . . . . . 19

3.3. Análisis de fortalezas y debilidades del sector, y de la competencia. . . . . 20

3.3.1. Análisis de fortalezas y debilidades del cerámico. . . . . . . . . . 20

3.3.2. Análisis de fortalezas y debilidades de la alfombra. . . . . . . . . 21

3.3.3. Análisis de fortalezas y debilidades de la madera. . . . . . . . . . 22

3.3.4. Análisis de fortalezas y debilidades del mosaico. . . . . . . . . . . 22

4. ACTIVIDADES ESTRATÉGICAS E IMPLEMENTACIÓN DEL PLAN

DE MARKETING. . . . . . . . . . . . . . . . . . 23

4.1. Alcance del trabajo. . . . . . . . . . . . . . . . 23

4.2. Oportunidad del proyecto. . . . . . . . . . . . . . . . . 24

4.3. Identidad, diseño y comunicación corporativa. . . . . . . . . . . 25

4.3.1. Eslogan de marca. . . . . . . . . . . . . . . . . . . 27

4.3.2. Marca y logotipo. . . . . . . . . . . . . . . . . . 29

4.3.3. Líneas comerciales. . . . . . . . . . . . . . . . 31 
4.3.4. Papelería, folletos y avisos publicitarios. . . . . . . . . . . 37

4.2.4.1. Aplicaciones del eslogan principal y secundarios. . . . . . 40

4.3.5. Rediseño del punto de ventas. . . . . . . . . . . . . . . . . . 45

4.3.6. Pagina Web institucional. . . . . . . . . . . . . . 56

4.3.7. CD interactivo institucional. . . . . . . . . . . . . 61

4.3.8. Video para publicidad institucional. . . . . . . . . . 61

4.4. Diseño de Producto. . . . . . . . . . . . . . . . . . 63

4.4.1. Nuevos diseños de mosaicos. . . . . . . . . . . . . . . . . 64

4.4.2. Diseños exclusivos de mosaicos. . . . . . . . . . . . . . 73

4.5. Características del personal de contacto y de ventas. . . . . . . . . . . 86

4.6. Guía metodológica para exposiciones. . . . . . . . . . . . . . . . . 87

5. MEDICIÓN DEL IMPACTO. . . . . . . . . . . . . . . . . . . . . . . . . 94

5.1. Evaluación y análisis de resultados. . . . . . . . . . . . . . . . . . 94

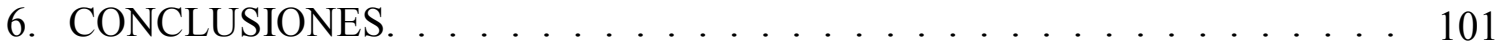

7. BIBLIOGRAFÍA. . . . . . . . . . . . . . . . . . 103 


\section{PRÓLOGO Y AGRADECIMIENTOS.}

Al realizar este prólogo, recordé el artículo de la revista Negocios ${ }^{1}$ que fortaleció mi decisión de cómo seguir formándome. Al poco tiempo de la culminación de la Carrera de Grado, iniciaba esta Maestría.

En esta ardua etapa de la Carrera de Postgrado en Marketing Internacional, la redacción de la Tesis, tuve la oportunidad de investigar en pro de alcanzar soluciones científicas para una problemática empresaria real.

A esto debo el agradecimiento al Profesor Ing. Enzo Campana, quien me invitó a participar en la asistencia a empresas y a los titulares de Mosaicos La Española, Arq. Clemente Rey e Ing. Jorge Rey.

Quisiera agradecer también al Director de la EPMI, Prof. Dr. Rogelio Simonato, por su constante empeño en aumentar la calidad académica a través de la organización de seminarios extracurriculares especialmente dictados para los alumnos del Magíster; y a la Secretaria Académica, Lic. Liesel Bischoff por su amabilidad e incondicional apoyo a lo largo de todo el Postgrado.

\footnotetext{
${ }^{1}$ En este artículo se exponían los Postgrados de Marketing en Argentina, de los cuales, a la EPMI se la posicionaba como pionera y se le distinguía la asistencia técnica y científica de la Export-Akademie de la Reutlingen de Alemania. (Pág. 104, "Para Venderse Mejor". Sección Aulas de la Revista NegOcios No 60, Agosto de 1996, Atlántida, Buenos Aires). 


\section{INTRODUCCIÓN.}

Según Umberto $\mathrm{Eco}^{2}$, se puede realizar una tesis de compilación o una tesis de investigación; o una tesis de licenciatura o de doctorado.

En una tesis de compilación el estudiante demuestra simplemente haber tomado una visión crítica de la mayor parte de la literatura existente (o sea de los escritos publicados sobre el tema) y de haber sido capaz de exponerla en un modo claro, buscando conectar los distintos puntos de vista. Ofreciendo así un panorama inteligente, tal vez útil desde el punto de vista informativo o desde un punto específico que, sobre un simple problema, nunca se había conducido ningún estudio profundo.

La tesis de doctorado constituye un trabajo original de investigación, en el cual el candidato debe demostrar ser un estudioso capaz de lograr dar un paso adelante a la disciplina a la cual se dedica. Este tipo de tesis, resulta normalmente de un trabajo de investigación que puede llevar como mínimo entre dos y cinco años. Esto, se debe a que se trata de una investigación original, en la que se necesita saber certeramente aquello que han dicho sobre el mismo tema otros estudiosos, pero se necesita descubrir algo de lo que todavía no se ha dicho.

Una tesis de investigación es siempre más larga y trabajosa; una tesis de compilación puede también ser larga y trabajosa (existen algunos trabajos de compilación que han tomado años y años) pero normalmente pueden ser realizadas en menor tiempo y con menor riesgo.

En una conversación mantenida con el Profesor Manzini ${ }^{3}$, éste explicaba que una maestría debería ser una formación orientada a la praxis, mediante el logro de un grado académico intermedio entre la licenciatura y el doctorado.

\footnotetext{
${ }^{2}$ Eco, Umberto, Come si fa una Tesi di Laurea, Bompiani, Milano 2000.

3 ManzINI, EzIO, Ingeniero y Arquitecto, es Profesor, Director del Master en Diseño Estratégico y Coordinador del Doctorado en Diseño Industrial del Politecnico di Milano.
} 
En lo que a mí respecta, una Tesis de Magíster debería estructurarse en el desarrollo de una práctica profesional de la disciplina, en la cual, con el sustento conceptual de material teórico-científico se fundamenten las acciones concretadas.

Durante el desarrollo del Master en Marketing Internacional que dicta la EPMI, tuve la oportunidad de conocer al Profesor Ing. Enzo Campana, docente de las materias Fundamentos de Marketing y Sistemas Aplicados al Marketing I y II.

Al finalizar la cursada, fui convocado por él para participar en trabajos de consultoría a empresas. Esta experiencia me permitió conocer desde el seno mismo de una empresa industrial, las diferentes problemáticas ${ }^{4}$ y las posibles soluciones que pueden estructurarse en un Plan de Marketing.

El presente trabajo de Tesis, está conformado con documentación de la asistencia realizada a una empresa local de la industria del mosaico.

El desarrollo principal de este proyecto se basó en dos etapas clave:

A. Analizar la situación actual de Mosaicos La Española, efectuar un diagnóstico detallado de las áreas clave de la compañía y presentar un Plan de Acción Comercial que establezca factores de crecimiento en el corto, mediano y largo plazo.

B. Desarrollar, en función de la Estrategia de Empresa y Comercial diseñada, los elementos operativos necesarios que permitan la conclusión de estos planes y objetivos.

\footnotetext{
${ }^{4}$ BRUNo MunARI cuenta que su amigo ANTONIO REBOLInI dice: "Cuando un problema no se puede resolver, no es un problema. Cuando un problema se puede resolver, no es un problema". Y es verdad efectivamente. Pero esta afirmación trae algunas observaciones: se necesita primero de todo saber distinguir si un problema es resoluble o si no lo es. Y para saberlo es necesaria la experiencia. (MUNARI, BRuno, Da Cosa Nasce Cosa; appunti per una metodología progettuale, Laterza, Bari 1981).
} 
El alcance del proyecto cubrió los siguientes puntos según los siguientes mercados:

\section{Mercado Masivo:}

- Desarrollo de producto y posicionamiento de marca.

- Diseño de una línea de productos con un nuevo concepto.

- Desarrollo de discurso de marca.

- Diseño de folleto institucional.

- Diseño de material de promoción.

- Diseño de mensaje publicitario (publicidad estática).

- Diseño de mensaje publicitario (publicidad en medios gráficos).

- Rediseño del punto de venta.

\section{Mercado Técnico:}

- Colaboración en selección de personal.

- Capacitación del personal.

- Generación de un programa de tareas comerciales efectivo.

- Evaluación y análisis de resultados.

\section{LA EMPRESA.}

\subsection{Antecedentes históricos y filosofía empresarial.}

En el año 1954 Don Francisco Rey Tormo, procedente de Barcelona, llega a la Argentina junto a su familia. 
Junto a su hijo Luis Rey Vernis montan una pequeña empresa totalmente artesanal de fabricación de mosaicos. A estos pioneros, se les une en poco tiempo Teresa, esposa de Luis.

Fueron años difíciles, llenos de esfuerzo y sin sabores, pero también eran años de crecimiento, y esos esfuerzos dieron sus frutos.

En la década del setenta fue una de las primeras empresas en poseer máquinas automáticas para fabricar mosaicos con tecnología nacional que permitía con muy pocos operarios cubrir la demanda de una ciudad en constante crecimiento como lo era La Plata.

En el año 1987 con sus flamantes títulos de arquitecto e ingeniero civil, toman la conducción de la empresa Clemente y Jorge Rey, nietos de aquel pionero fundador, iniciando una nueva etapa.

Se construye una planta industrial modelo sobre un predio de más de siete hectáreas, trabajando siempre con una filosofía de puertas abiertas a las nuevas tecnologías.

Compran la primera máquina de tecnología europea totalmente automática, anexándole equipos de dosificación y extracción automática desarrollados por el personal altamente calificado de la empresa.

Hoy partiendo de materias primas tan nobles como la arena, el cemento y piedras de todo el mundo, controladas por un riguroso sistema de calidad, confluyen en la fabricación a través de máquinas que incorporan lo último en tecnología del mundo de mosaicos, que cumplen sobradamente las expectativas del consumidor más exigente. 
Pero la tecnología no es todo, importa más el componente principal en la fabricación de cualquier producto, el Cliente ${ }^{5}$.

A través de distintos puntos de venta propios y de terceros la empresa esta en permanente contacto con los clientes, participando en sus necesidades y expectativas en un constante desarrollo de productos con las últimas tendencias en diseño ${ }^{6}$ del mundo, sin olvidar las fuentes que son los clásicos diseñadores catalanes en la industria de la construcción.

Hoy, con más de cuarenta años de historia, la empresa esta presente con sus productos en numerosos edificios públicos y particulares, entre ellos, algunos que ya son historia en el país, así como participando activamente en el crecimiento de este con su constante presencia en las principales construcciones actualmente en ejecución, haciendo una realidad la frase que la caracteriza: Mosaicos La Española, con la personalidad de tus sueños.

\subsection{Realidad actual de la empresa.}

La recesión instalada en Argentina a mediados de 1998 y que persiste aún hoy incisivamente, está debilitando al máximo la capacidad de supervivencia de las PyMIs. Los ingresos por ventas de estas empresas provienen en un $90 \%$ del mercado interno y las inversiones se financian fundamentalmente utilizando recursos propios, de manera que puede comprenderse la magnitud de los ajustes que están realizando actualmente las empresas.

\footnotetext{
5 "El proyectista es el que coloca al hombre delante de la tecnología, a su servicio, mientras que la tendencia del científico es la de poner la tecnología delante del hombre". (MirANDA, SANTIAGO en "Maestros del Diseño Español").

6 "El diseño es sobre todo lenguaje, comunicación. Lenguaje quiere decir unos códigos, una estructura lingüística. Eso es para mí el diseño". (FARRÉ-ESCOFET, EMILI, en una entrevista con el autor. ARIAS, JUAN, Maestros del Diseño Español, identidad y diversidad, Experimenta, Madrid 1996.
} 
Mosaicos La Española ${ }^{7}$ está sufriendo en la actualidad un retroceso importante en su proceso de crecimiento, debido, en gran parte a la inercia recesiva del sector.

Este proceso está generado principalmente, por las siguientes causas:

- Recesión natural del sector, frente a otras alternativas mejor posicionadas en la actualidad, como por ejemplo: el cerámico.

- Estancamiento en el desarrollo de nuevas líneas de productos y noadecuación a los requerimientos actuales del público objetivo.

- Obsolescencia en la oferta de productos.

- Proceso de comunicación con el cliente anticuado y obsoleto, manteniendo los conceptos antiguos del mosaico como mensaje hacia el cliente.

A partir de estas, se estableció una metodología de análisis ${ }^{8}$ de potenciales mejoras que cubrieron los siguientes aspectos:

- Análisis comunicacional escrito.

- Análisis de atención telefónica. Posicionamiento competitivo.

- Análisis detallado de fortalezas y debilidades del sector mosaicos y comparativo con otros sectores competencia directa (cerámico, madera y alfombra).

- Diseño de discurso de marca y adecuación al logotipo de la empresa.

- Informe de sugerencias de punto de venta y diseño de punto de venta.

- Ampliación de la cartera de productos, oferta y comunicación, diseñando nuevos mosaicos novedosos con las herramientas de comunicación para proyectarlos al mercado.

\footnotetext{
${ }^{7}$ La empresa cuenta con veintidós empleados, lo que la define como una Pequeña y Mediana Industria (PyMIs: 11 a 200 ocupados), denominación utilizada por la Unión Industrial Argentina.

${ }^{8}$ La ciencia está adquiriendo cada vez mayor importancia en el desarrollo de métodos de análisis; estos métodos pueden clasificarse según la cantidad de teoría y de procedimiento científico que exista en ellos. El enfoque científico y totalmente objetivo se encuentra en un extremo de dicha clasificación, mientras que el enfoque basado en la intuición, la experiencia y la praxis subjetiva está ubicado en el otro. Por lo general se usa una mezcla de los dos extremos para solucionar la mayoría de los problemas.
} 


\subsection{Análisis comunicacional en publicidad.}

En la promoción de los productos intervienen dos elementos, y ambos relacionan los esfuerzos de venta con el mercado:

- Mensaje del Producto: en éste, deberían describirse los productos de forma que los clientes puedan reconocer las ventajas al comprarlos.

- Forma de Comunicación del Mensaje: aquí se deberían seleccionar los canales de marketing con los que se desea llegar a la audiencia objetivo.

Los elementos precedentes, han sido analizados desde cada canal de promoción que utiliza La Española.

\subsubsection{Guía telefónica.}

Se trabajó sobre la guía telefónica del año 2000 de la cuidad de La Plata, buscándose el rubro mosaicos, y se analizaron los avisos desde el punto de vista del consumidor.

El comienzo del rubro esta en pagina izquierda, en la parte inferior derecha de la pagina, que es una de las peores zonas de ubicación en gráfica, finalizando el mismo en la pagina siguiente en el sector superior izquierdo.

Dentro del mismo se encuentran varios avisos con distintos tamaños y formatos.

El primero que se destaca es el de firma Fioravanti, y las razones son:

- Es el de mayor tamaño.

- Está en página derecha.

- Tiene mucho espacio en blanco alrededor del texto.

- Se destaca el texto fabricación automática que habla de tecnología.

El segundo que se destaca es el de la firma Canalini y las razones son:

- Es el único que utiliza grafica en el aviso. 
- Se destaca el texto fabricación automática que habla de tecnología.

- Es el segundo en tamaño.

Le sigue la firma Di Domenicantonio por:

- Por razones alfabéticas es el primero de la lista.

- El aviso es algo más grande que el siguiente.

Por ultimo continúa la firma La Española Mosaicos por:

- Es de menor tamaño que el de Di Domenicantonio.

- Se utilizó el color rojo para destacarlo, pero sobre amarillo se empasta perdiéndose el objetivo.

- Tiene demasiado texto lo que pierde el mensaje.

- Como positivo repite en página derecha el aviso bajo el subsector Lisandro Olmos.

\section{Conclusiones parciales:}

La estrategia comunicacional en guía telefónica poseía multitud de defectos tanto propios como relativos, lo que significa que se encuentra en gran desventaja frente a la competencia.

Se recomendó rediseñar el aviso publicitario en guía, buscando adecuarse a las nuevas definiciones de comunicación que se reflejan en este informe.

A continuación se puede observar la cronología de la publicidad aplicada en las páginas amarillas de la guía telefónica. 


\section{Guía telefónica - Año 2000:}

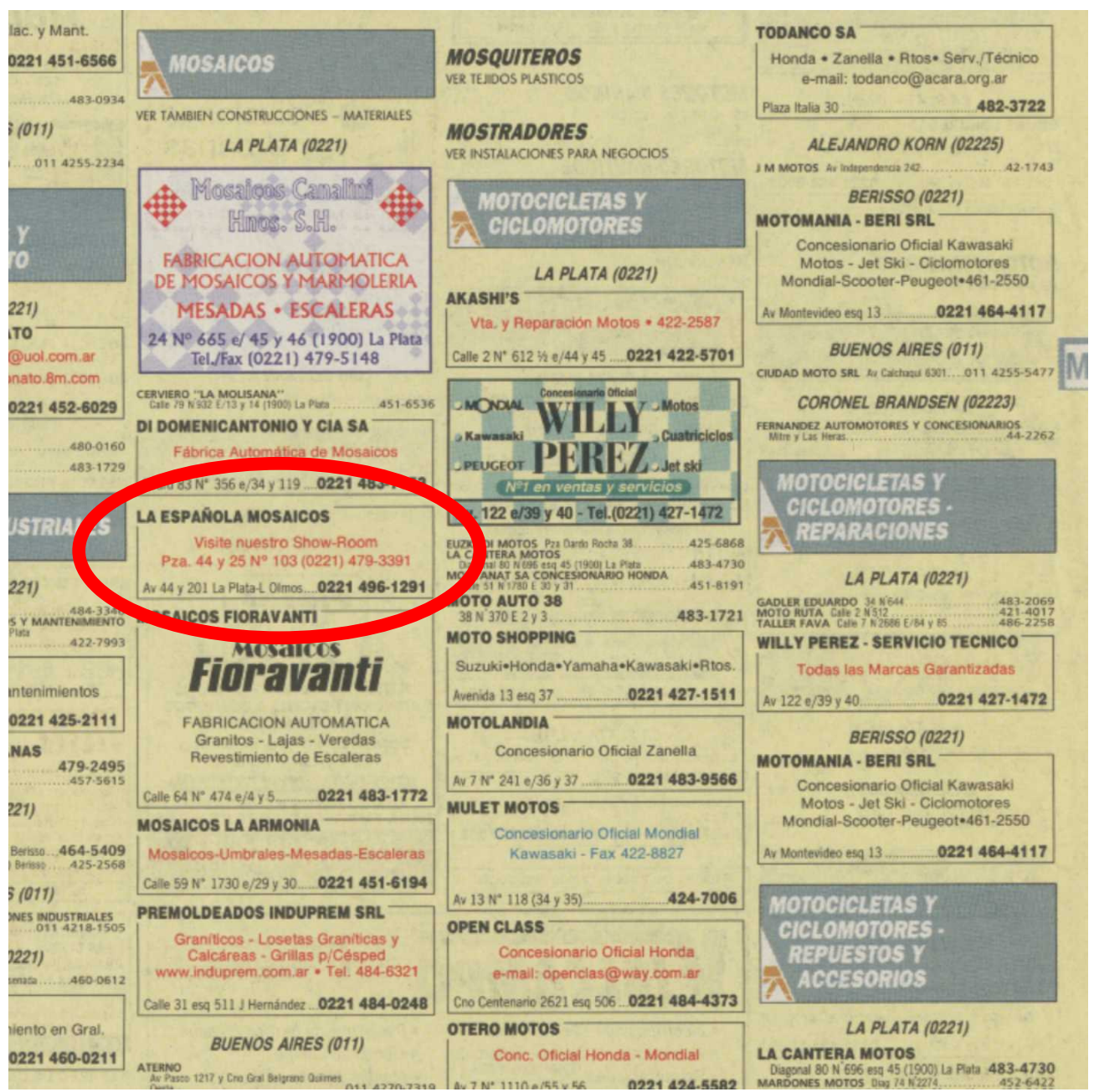




\section{Guía telefónica - Año 2001:}

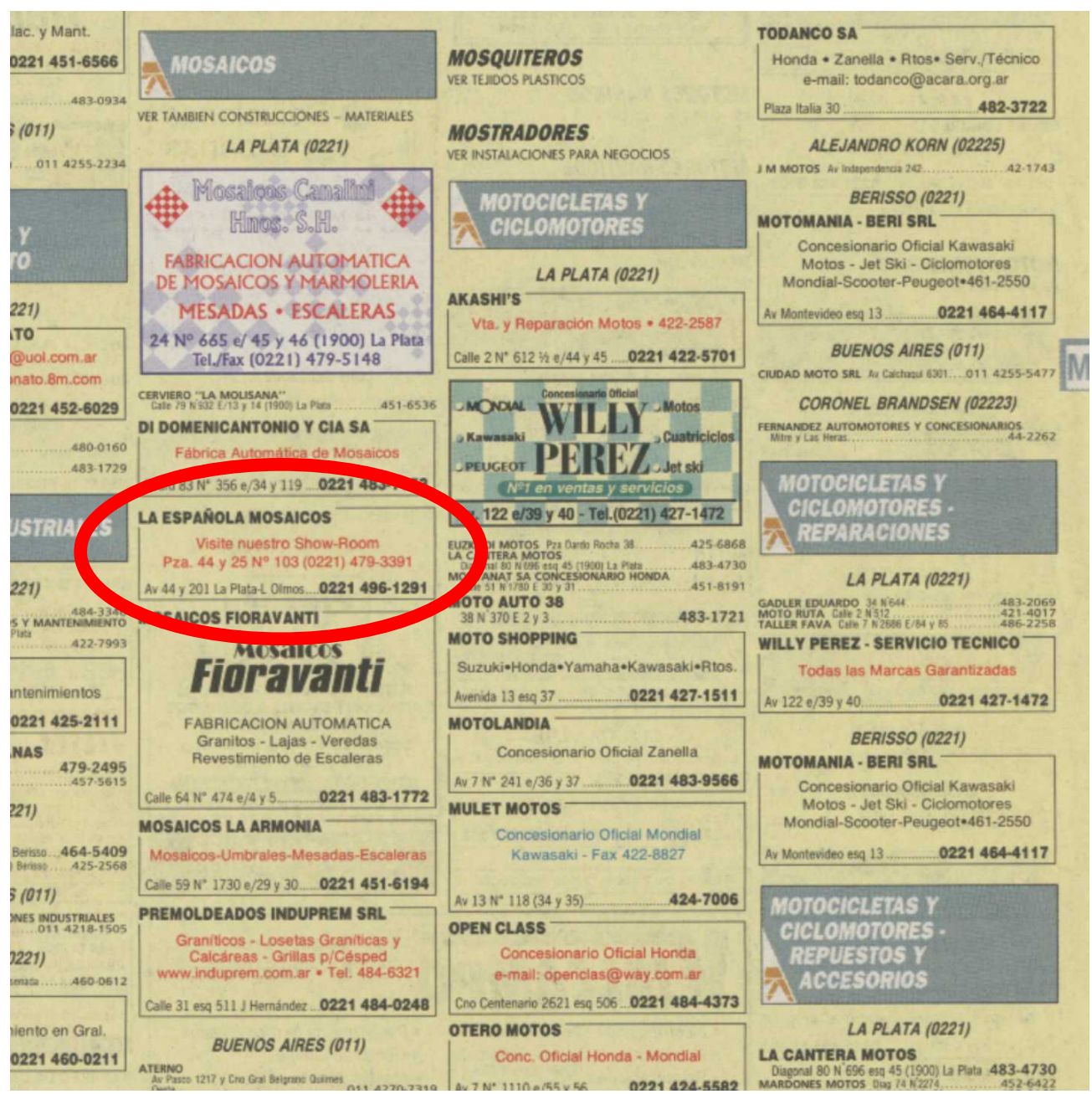

\subsubsection{Revistas.}

Se analizó el aviso publicitario publicado mensualmente en la revista de cable de la zona.

El mismo apuntaba a un discurso institucional y tecnológico, la diagramación del mismo es interesante y coherente salvo algunos de ellos en que aparecen pequeñas incoherencias, por ejemplo el publicitar una línea italiana de mosaicos. 
El único punto cuestionable era el discurso técnico del aviso publicado en una revista dirigida especialmente a la mujer.

Se aconsejó ajustar el mensaje y destinarlo al mercado técnico, utilizándolo como parte de la folletería comercial, o publicarlo en revistas especializadas dirigidas al sector de la construcción.

\subsection{Análisis de la marca y logotipo de la empresa.}

Del análisis de comunicación institucional de La Española, se desprendieron distintos resultados, donde se comprobó positivamente que la marca ${ }^{9}$ y su logotipo son reconocidos por el público local; pero sin posibilidades de adjudicársele una característica particular a la política productiva y comercial de la empresa.

También se detectó, que los clientes pertenecientes a los distintos mercados pueden valorizar la historia de esta emprendedora industria familiar.

\subsection{Relevamiento de la atención telefónica.}

Se realizó un relevamiento de las empresas fabricantes de mosaicos que figuran en guía telefónica de la ciudad de La Plata.

En todos los casos se les dijo que hablaban de la Municipalidad de Florencio Varela, y que necesitaban precio por $500 \mathrm{~m}^{2}$ de mosaico de vereda tipo vainilla. El precio debía incluir flete hasta la ciudad de Florencio Varela

\footnotetext{
${ }^{9}$ Según PHILIP KOTLER: "Una marca es un nombre, pero cuando la marca es poderosa hace pensar en muchas cosas más, no solo en el nombre. Uno puede hacer la prueba preguntándole a la gente qué es lo que le viene en mente cuando la ve. Si dicen solo el nombre, entonces no es una marca fuerte. Para que sea una marca sólida tienen que venirle muchas, pero muchas cosas a la cabeza. Pueden ser varias: las personalidades de los que fundaron la empresa, el nombre de algunos de sus funcionarios, la calidad, el servicio, las oficinas de la empresa, etc.”. (Pág. 100, “El Desafio de Crear Experiencias”. Sección File de la Revista Gestión Vol. 2 N 5, Septiembre-Octubre de 1997, Buenos Aires Review).
} 


\section{Resultados del relevamiento:}

Di Domenicantonio, Tel.: 483-7153

Atiende una voz femenina que saluda: "Fabrica de mosaicos, buenos días", ante el requerimiento del encuestador le contesta un momento por favor y transfiere la llamada a un hombre que no se presenta.

Este cotiza el mosaico a $\$ 5+$ IVA y aclara que tiene incluido el flete a Florencio Varela.

\section{Canalini, Tel.: 479-5148}

Atiende una voz femenina que saluda: "Fabrica... buen día", ante el requerimiento del encuestador consulta con otra persona (se oyen las voces) y luego contesta: " $\$ 6+I V A$, puesto en Florencio Varela".

\section{La Española, Tel.: 479-3391}

Atiende una voz femenina que dice: "Hola", ante el requerimiento del encuestador, le dice que tiene que llamar a los teléfonos 496-2066 o 496-1291, el encuestador se desorienta y pregunta si esa no es la fabrica de mosaicos que figura en guía, allí la voz femenina le informa que el teléfono que le dio es el de fabrica y que ella atiende comercio minorista.

El encuestador llama al primer teléfono que da ocupado, ya molesto llama al segundo teléfono donde atiende una voz femenina que dice: "La Española...", ante el requerimiento del encuestador le dice: "un segundito", se oyen movimientos de papeles y luego le cotiza $\$ 6$ + IVA, ante el requerimiento del flete le contesta que no hay inconvenientes y que esta incluido en el precio.

Fioravanti, Tel.: 483-1772

Atiende una voz masculina que dice: "Fioravanti, buen día", ante el requerimiento del encuestador le informa que tiene en dos tipos, 20x20 hechos a mano a $\$ 9,50+$ IVA y $25 \times 25$ hechos en forma automática a $\$ 7,50+$ IVA, ambos precios incluyen el flete a Florencio Varela. 
La Armonía, Tel.: 451-6194

Atiende una voz masculina que dice: "La Unión, buen día", ante el requerimiento del encuestador le informa que tiene en dos tipos, uno hecho con placa de goma en rustica a un precio de $\$ 7,50+$ IVA y otro hecho con plancha de metal a $\$ 9,50+$ IVA, ante el requerimiento del flete le informa que le resulta muy difícil y que si no pueden ir de la municipalidad a retirarlo.

\section{Conclusiones parciales:}

No existe en el sector, ninguna empresa que se destaque en su nivel de atención telefónica. Es de destacar que ninguna empresa optó por la consigna de: “ $X X X$ (nombre de la empresa), buenos días (o buenas tardes, según corresponda), habla YYY (nombre del operador), ...¿¿n qué puedo ayudarle?”, que consideramos imprescindible en la atención personalizada y que se recomendó a La Española por las siguientes características:

- Denota un claro acercamiento al cliente.

- Ofrece una actitud de servicio y de solución de problemas (característica bastante habitual en las consultas telefónicas en las que el cliente no sabe con certeza que quiere en la mayoría de los casos y busca más que un producto, un asesoramiento).

Esta introducción debe estar acompañada por una voz femenina que refuerce esa actitud de ayuda y de asesoramiento, utilizando un tono dulce, atento y respetuoso para con el cliente.

\subsection{Análisis del punto de ventas.}

Ha sido difícil analizar comparativamente los puntos de venta entre La Española y los otros fabricantes de mosaicos, ya que todos poseen puntos de venta deslucidos y sin una característica que denote algo de jerarquía o actualidad. 
El mensaje que se percibe en todos ellos es el de querer vender tecnología, historia y mucho esfuerzo, y aunque no lo expresen, parecen estar convencidos que su cliente es del sexo masculino (ingeniero, arquitecto, albañil, propietario, comprador de empresa, etc.).

Dentro de este contexto La Española se destaca por ser el primero que monta un local para la venta minorista especializado en mosaicos, aunque el discurso del local es similar al del resto de las empresas.

El análisis más enriquecedor, fue analizar el negocio de solados en general, y no solo desde el rubro mosaicos. Esto obligó a analizar además los rubros cerámicos, alfombras y maderas.

Tanto la madera como la alfombra fueron competidores clásicos del mosaico, aunque a partir de la década del '60 en adelante aplicaron la madera fundamentalmente en dormitorios y en algunos casos en livings.

La alfombra nació como un complemento del piso pasando a ocupar posiciones en los dormitorios, livings y en algunos casos comedores.

En la década del '70 el cerámico que hasta ese momento era dueño de las paredes, baja al piso convirtiéndose en una opción interesante por su costo y sus tonos cromáticos, pasando con el tiempo a convertirse en el líder de los pisos en el interior de la casa. El único punto débil que tenía era su duración y más tarde lo resolvió la industria desarrollando el porcelanato.

En función de estas características y de las mejoras sugeridas en el análisis comunicacional (eslogan), se destacó la importancia de diferenciar los dos tipos de mercado existentes, que requieren distintos tipos de presentación y diseño del punto de venta.

Para cada uno de estos casos, se recomendó desarrollar las siguientes definiciones: 
- Mercado masivo: incorporar los conceptos estéticos antes detallados y seguir un diseño de punto de venta totalmente dirigido a este segmento.

- Mercado técnico: ofrecer un servicio de atención en fábrica, claramente orientado hacia un público masculino experimentado, y ofreciéndole una atención dirigida y técnicamente completa, ampliando al producto hacia una combinación de producto físico y de servicio de asesoramiento profesional.

\section{ANÁLISIS DE LOS MERCADOS.}

Actualmente, en las actividades comerciales del mosaico, se pueden detectar dos diferenciaciones principales en el tipo de comprador: la compra para uso directo e indirecto, lo que ayudó a distinguir a los mercados que se denominarán: Masivo y Técnico.

\subsection{Mercado Masivo.}

El Mercado Masivo está caracterizado por poseer criterios estéticos personales para la selección de los productos. Emplean mayor tiempo y realizan la búsqueda del producto ideal. Con paciencia buscan combinaciones y reflexionan sobre las nuevas tendencias del diseño de interiores.

Este mercado, por lo general está compuesto por la mujer o por los miembros responsables de la familia, en pocas ocasiones acompañados de niños.

\subsection{Mercado Técnico.}

El Mercado Técnico está conformado por los profesionales del proyecto y la producción de viviendas, edificios, y otras construcciones civiles. Entre los que se encuentran ingenieros civiles, arquitectos, maestros mayores de obra, albañiles y otros. 
Éstos, poseen todavía los criterios de selección tradicionales y buscan un mosaico por las características de durabilidad y resistencia.

Requieren información técnica especializada, pero no dedican demasiado tiempo para la elección del producto y la decisión de compra. Normalmente, tienen ya predefinido el modelo del producto que desean adquirir.

Gran parte de este mercado está orientado a precios bajos.

\subsection{Análisis de fortalezas y debilidades del sector, y de la competencia.}

Para determinar potenciales puntos de acción y de recuperación de mercados que anteriormente eran exclusivos del mosaico, se realizó un análisis de fortalezas y debilidades tanto del sector mosaicos como de sus sustitutos.

Esta competencia indirecta está hoy constituida por el cerámico, la madera y la alfombra.

\subsubsection{Análisis de fortalezas y debilidades del cerámico.}

\section{Fortalezas:}

Por sus orígenes, (se vendía como complemento de baños y cocinas), este canal se convirtió en el distribuidor inicial de cerámicos, a diferencia del mosaico que se distribuía en corralones o empresas fabricantes de mosaicos lo que hacia que se considerara como complemento de la construcción del edifico.

Esto genera las siguientes ventajas diferenciales fundamentales:

- Aparece la mujer como compradora. 
- Se comienza a pensar en el cerámico como parte de la decoración y no como parte de la estructura del edificio.

- Se comienza a pensar en la reposición del mismo con el tiempo.

- Hay una gran variedad de oferta de formatos, diseños y colores.

- Es fácil de limpiar.

\section{Debilidades:}

El producto tiene incorporadas algunas desventajas que hoy son perfectamente conocidas por el consumidor que son:

- No es resistente, se desgasta con el tiempo y pierde brillo.

- Acumula suciedad en las juntas difíciles de limpiar.

- No es constante en sus colores, ni siquiera dentro de una misma partida (hoy la tecnología mejoro mucho esta debilidad).

- Pasado un corto periodo de tiempo si el consumidor quiere comprar piezas para reparación o para ampliar no se consiguen, o si se consiguen al ser de distinta partida el tono no es el mismo.

Esto genera un inconveniente adicional para los canales de distribución, dentro del canal existe hoy una gran cantidad de metros de cerámico sobrantes de entregas que son invendibles.

\subsubsection{Análisis de fortalezas y debilidades de la alfombra.}

\section{Fortalezas:}

- La principal fortaleza de la alfombra es su calidez, textura y colorido.

- Al nacer del rubro textil, ingresa al mercado de la mano de los revestimientos convirtiendo a la mujer en la principal protagonista a la hora de decidir.

- Permiten una fácil reposición. 


\section{Debilidades:}

- Son difíciles de limpiar.

- Marcan la textura de la base.

- Son altamente sensibles a quemaduras, roturas y derrames de productos de difícil limpieza.

\subsubsection{Análisis de fortalezas y debilidades de la madera.}

\section{Fortalezas:}

- Es cálida.

- $\quad$ Tiene prestigio, su discurso habla de familia y abolengo.

\section{Debilidades:}

- Al igual que el mosaico, al nacer del negocio de la carpintería se lo consideraba un componente de la construcción.

- Es difícil de limpiar (hoy resuelto con el plastificado de pisos).

- Es sensible a los golpes.

\subsubsection{Análisis de fortalezas y debilidades del mosaico.}

\section{Fortalezas:}

- Resistencia, es el único material que al igual que las piedras trasciende a su colocador.

- Es de fácil limpieza.

- Una vez pulido no presenta discontinuidades al tacto.

- Permite que el consumidor participe en el diseño del mismo.

- Amplia variedad de formas, diseños y colores.

\section{Debilidades:}

- Es de difícil colocación y reposición. 
- Es de alto costo.

- Ha dejado de lado a la mujer como cliente.

\section{Conclusiones parciales:}

Claramente se observó que la principal competencia y el competidor más cercano en nuestro segmento de mercado, es el cerámico. Las características y fortalezas de este sector, nos hacen recomendar una estrategia de posicionamiento y oferta similar para reencauzar el desarrollo del sector mosaicos en la empresa. Estas características deberán ser:

- Incorporar a la mujer como compradora y dirigir las herramientas comunicacionales hacia ella como responsable de la decisión.

- Reajustar el concepto del mosaico, más que como un elemento de construcción, también como un elemento decorativo, incorporando nuevos diseños y formas. De esta forma, podemos hacer convivir tanto las ventajas tradicionales ${ }^{10}$ (durabilidad, fortaleza, etc.) Con nuevas ventajas mucho más modernas y orientadas hacia lo estético y también más atractivas para nuestro nuevo comprador (la mujer).

\section{ACTIVIDADES ESTRATÉGICAS E IMPLEMENTACIÓN DEL PLAN DE MARKETING.}

\subsection{Alcance del trabajo.}

\footnotetext{
10 "Cuando se piensa en productos realizados con cuatro materiales diferentes como lo son la paja, la madera, la piedra y el oro. Cada un de ellos define emblemáticamente una existencia diferente de las cosas en el tiempo. Esta diversidad no solo consiste en su duración absoluta (breve para el primer material, media para el segundo, larga para el tercero y, en la escala del tiempo del hombre, prácticamente eterna para el cuarto), sino también en la forma de comportarse en el tiempo en que la duración tiene lugar: la paja se degrada tan rápidamente que requiere tales y continuos mantenimientos que hacen que en definitiva, el producto sea siempre nuevo. La madera tiene una vida y se degrada de tal forma que podemos percibir su lenta evolución. La piedra se cubre de una sutil pátina (la patina del tiempo), pero su verdadera degradación se puede observar a lo largo de tiempos históricos (tan largos, que a menudo quien causa la ruina es la acción destructiva del hombre y no la del ambiente). El oro, por último, parece incorruptible y es este excepcional comportamiento suyo, lo que parece separarlo de la mayor parte de los demás materiales, donde radica una de las bases principales de la atribución de su valor". (MANZINI, EZIO, Artefatti. Verso una nuova ecología dell'ambiente artificiale, Domus Academy, Milano 1990).
} 
Si bien, en este trabajo se han considerado y analizado distintos aspectos de la actualidad de la empresa y de los distintos mercados donde participa, esta tesis se abocó al desarrollo de las estrategias de imagen corporativa ${ }^{*}$ y de atención al cliente (véase detalle de cada mercado en el punto 1).

\subsection{Oportunidad del proyecto.}

En un entorno integrado y global, caracterizado por un aumento del número y la calidad de la competencia y por una reducción considerable de la participación de mercado, La Española como la mayor parte de las compañías deben analizar de forma urgente su grado de eficiencia en cada uno de los procesos que desarrolla, buscando:

- Establecer y cumplir objetivos y planes de negocio a corto, mediano y largo plazo.

- Ofrecer un soporte adecuado y un nivel de servicio al cliente cada vez más elevados.

- Aumentar la eficiencia y efectividad de sus actividades comerciales.

- Y sobre todo, crear un entorno de comunicación cliente-empresa que le provea de un factor diferenciador pro-activo, claro y adecuado para con su mercado objetivo.

Muchas compañías están hoy experimentando los síntomas del proceso de transformación empresarial que se está produciendo en nuestro país (reducción importante del volumen de ventas, aparición de agresivos competidores y productos sustitutos en el mercado que ponen en peligro la supervivencia de la empresa).

Una reacción temprana puede permitir superar y revertir estas situaciones negativas invirtiendo en el momento apropiado los esfuerzos necesarios. Más tarde puede significar "demasiado tarde".

\footnotetext{
${ }^{*}$ Referido en el sentido amplio de imagen corporativa. BERNHARD E. BÜRDEK, Profesor de la Hochschule für Gestaltung (Offenbach), lo define como la imagen pública de la empresa que se expresa a través de la comunicación corporativa y el diseño corporativo de todos sus componentes.
} 
Mosaicos La Española se encuentra en un punto de desarrollo ideal para plantearse este proceso de revisión interna y de diferenciación comercial, de forma que pueda enfrenar el nuevo entorno empresarial y analizar nuevas alternativas de negocio con perspectivas de éxito y crecimiento, y sobre todo con una mejor oferta comercial a sus clientes.

Por ello, se propuso generar un plan ${ }^{11}$ de desarrollo comercial efectivo que le permita a La Española conseguir el grado de diferenciación buscado.

Según Weiss ${ }^{12}$, el proceso de planificación es la principal herramienta de ayuda para las tomas de decisiones. Para dar solución a un problema general o particular, siempre es necesario desarrollar una serie de acciones de distinta naturaleza, cuyas ventajas y desventajas deberán ser evaluadas a priori. También deben reconocerse aquellas acciones que tienen capacidad de ejecutarse.

Es conveniente que el plan que se desarrolle sea concreto (en vez de general), lógico, práctico, basado en hechos y flexible a modificaciones.

\subsection{Identidad, diseño y comunicación corporativa.}

La teoría de la comunicación, muestra que una empresa en el encuentro con el público actúa como emisor de mensajes, los cuales son transmitidos por diversos canales y vehículos. En este proceso el receptor siempre adquiere información, se apliquen o no esfuerzos específicos. Si se aplican esfuerzos orientados a crear y consolidar estereotipos de opiniones positivas, estos actos estarán dotados de un interés persuasivo y no cognoscitivo ${ }^{13}$.

Dentro de las posibilidades para emprender una estrategia corporativa, se encuentran:

\footnotetext{
11 "La función de planificación debe permitir proyectar una organización que sea simultáneamente dinámica y flexible y que lleve incorporada la capacidad de crecimiento". (O'HARA, PATRICK D., El Plan Empresarial Integral: cómo prepararlo, redactarlo y revisarlo, Deusto, Buenos Aires 1993).

12 "Los planificadores más hábiles tienen imaginación y talento creativo. Un planificador eficiente establece un buen balance entre el optimismo y el pesimismo y tiene un punto de vista tanto práctico como realista." (WeIss, W. H., Guía Práctica para la Toma de Decisiones, Norma, Bogotá 1987).

${ }^{13}$ GÜI BONSIEPE (1978).
} 
- Comunicación visual.

- Diseño del Producto.

- Interiorismo.

- Arquitectura.

El resultado de todo estudio de identidad corporativa, debe llevar a representar la identidad del interior y del exterior de una empresa (concepto de Bodo Rieger, 1989). Por lo tanto, la imagen corporativa debe construir una imagen en el público de la realidad y características de la empresa.

El principal objetivo de este valioso punto estratégico es el de reflejar determinadas acciones tendientes a la renovación de la imagen ${ }^{14}$ empresarial pretendida. Aquí, se incluyen los parámetros de la nueva imagen de Mosaicos La Española. Así mismo, se incluyen los diseños desarrollados para folletería e imagen de la empresa para los distintos públicos clientes de la empresa:

- Masivo: Dirigido fundamentalmente a la mujer como protagonista de las decisiones en el proyecto o modificaciones del hogar.

- Arquitectos, diseñadores de interiores y profesionales de la construcción como incentivadores del proceso de compra y de la selección de materiales.

- Empresas constructoras, Organismos públicos y otros usuarios del mosaico en grandes superficies que buscan un material resistente, sólido y de fácil instalación.

\footnotetext{
14 "El Marketing tiene que trabajar muchísimo para desarrollar una imagen sólida de la marca a fin de que el cliente tenga la sensación de que si compra esa marca va a obtener valor. Pero esa imagen puede verse afectada, por ejemplo, por el contacto con el vendedor de la compañía, que no está a la altura de la misma, o por el packaging del producto que puede estar deslucido o llenándose de polvo en el estante más bajo de la góndola. Demasiadas personas en las compañías pasan el tiempo manejando la imagen de la marca sin manejar el contacto y la experiencia que tiene la gente con la marca. Deben tenerse en cuenta todos los puntos de contacto con la marca, que impresión recibe a través de la publicidad o del packaging, etc. y qué es lo que pueden hacer ellos para controlar esos contactos, de modo que se transformen en momentos de la verdad positivos."(KOTLER, PHILIP, 1997).

"La identidad se refiere a todas las formas en que una compañía se presenta al mundo exterior. Esto incluye publicidad, empaque, camiones, papelería. La imagen de una compañía, en cambio, es el resultado de esta identidad. Es la percepción de la compañía por todo su público, creada por la identidad. La identidad es causa; la imagen efecto.” (POPE, JEFFREY L., Investigación de Mercados, Norma, Bogotá 1997).
} 


\subsubsection{Eslogan de marca.}

Éste, deberá reflejar la nueva imagen que se quiere generar para La Española, en función de las mejoras que se deben incorporar $y$ de las características $y$ posicionamiento relevados.

\section{Criterios de desarrollo de discurso de marca:}

Durante el relevamiento y detección de potenciales puntos de mejora, se identificaron algunos conceptos que debemos remarcar y desarrollar en el discurso de empresa tendientes a resolver las fallas identificadas y a generar el nuevo posicionamiento identificado en el análisis de fortalezas y debilidades. Estos conceptos son:

- Incorporar a la mujer como compradora, y detectar las necesidades e impulsores de compra en ésta ${ }^{15}$.

- Incorporar el concepto estético y de decoración, perdido por el sector mosaicos.

- No olvidar aspectos de resistencia, durabilidad, etc.; exclusivos de este sector y difícilmente incorporables en otros productos de la competencia.

Adicionalmente, los discursos fueron orientados hacia conseguir la combinación de dos o más características del mosaico, intentando recuperar una de ellas de las características positivas tradicionales, e incorporando una segunda característica novedosa y orientada hacia las nuevas necesidades del público objetivo, como por ejemplo:

\section{Tradicionales:}

- Resistencia.

\footnotetext{
15 TOM PETERS, asegura que el "sexo débil" es la oportunidad comercial más fuerte y poderosa de la actualidad. "Las compañías deberían comprender que las mujeres representan hoy una gran oportunidad comercial. Son ellas las que toman la mayoría de las decisiones de compra o, de lo contrario, ejercen una influencia significativa sobre las mismas. La cuestión es que las mujeres son la mejor posibilidad del mercado. Hoy, no solo cuentan con más y mejores ingresos, sino que, además, están altamente preparadas para ocupar cargos ejecutivos y tienen de acuerdo a los resultados de un estudio, mejor educación que los hombres. Otro punto a favor es que parecen sentirse más seguras de sí mismas y subrayan aquello que las distingue". Además, dice que las mujeres compran más y compran por diferentes razones que los hombres. (Pág. 20, "El Poder de las Mujeres". Sección Marketing de la Revista Gestión Vol. 2 № 5, Septiembre-Octubre de 1997, Buenos Aires Review.)
} 
- Solidez.

- Calidez.

\section{Novedosos:}

- Diseño.

- Sueños y estética.

- Belleza.

A partir de la combinación de estos parámetros y las tendencias actuales ${ }^{16}$, se trabajó en distintos conceptos que se resumen a continuación:

- El fuego en tus pies.

- $\quad$ La solidez de tus sueños.

- El calor de la eternidad.

- La calidez de la eternidad.

- La calidez de tus sueños.

- El brillo y la textura que tus sueños hicieron realidad.

- Tus pensamientos hechos realidad.

- Tus sueños hechos realidad.

- Un mundo de sueños a tus pies.

- Únicos como tus sueños.

- Únicos como tu personalidad.

- Con la personalidad que tú le diste.

- Con la personalidad de tus sueños.

- Únicos como vos.

Finalmente, fue seleccionado el slogan:

"Con la personalidad de tus sueños", ya que incorpora los conceptos antes mencionados y comprende las siguientes características fundamentales:

\footnotetext{
16 "Probablemente los ochenta pasarán a la historia como los años de la creatividad y el formalismo, marcados con fuego por el tríptico creativo por excelencia: publicidad-moda-diseño. Sin embargo, durante la década que acaba de terminar la creatividad no se limitó a distinguir algunas actividades profesionales emergentes, sino que tendió a convertirse e una cualidad de la existencia cotidiana, en un modo de vida y de pensamiento. Se observó una creciente importancia cultural de fantasía y la imaginación entendidas como nuevos puntos de referencia, como nuevas claves de lectura de la realidad". (Morace, Francesco, Contratendencias, una nueva cultura del consumo, Celeste, Madrid 1993).
} 
- Está claramente dirigido a la mujer, de acuerdo a su importante rol en la definición de compra.

- Incorpora un concepto estético novedoso relacionado con los sueños.

- Mantiene la sensación tradicional, sólida y resistente por la incorporación de la "personalidad" del comprador.

\subsubsection{Marca y logotipo.}

Con respecto a la marca de la empresa, se trabajó manteniendo los siguientes criterios:

- Conservar y aprovechar la trayectoria de la empresa y el reconocimiento actual en su zona de influencia.

- Incorporar los conceptos novedosos generados.

Estas decisiones generan un conflicto de imagen en tanto en cuanto, cualquier modificación en la marca puede hacer perder la trayectoria conseguida por la empresa en la zona de La Plata, donde está posicionada como una de las primeras marcas de mosaicos.

Para resolver este conflicto se decidió:

- Conservar el diseño tradicional tipográfico de la marca.

- Conservar el logotipo asociado a la marca.

- Incorporar los nuevos conceptos como detalles de acompañamiento a la marca.

- Únicamente modificar el logotipo para adecuarlo a las nuevas exigencias de colorido y a la nueva diagramación de marca-eslogan.

Según esto, a continuación se resumen los diseños finalistas realizados y la opción final seleccionada. 
Oscilaciones del logotipo:

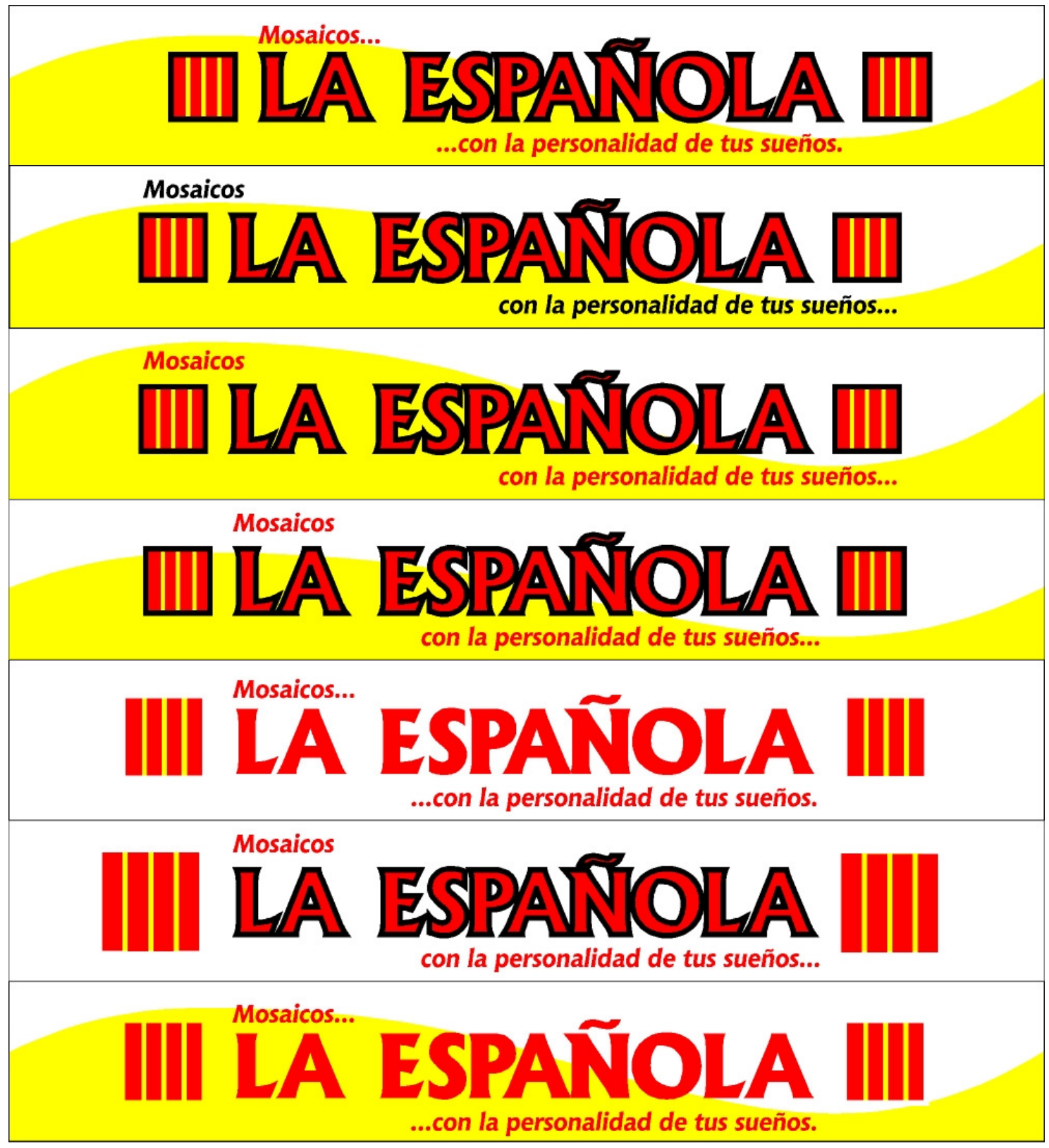

Opción final seleccionada:

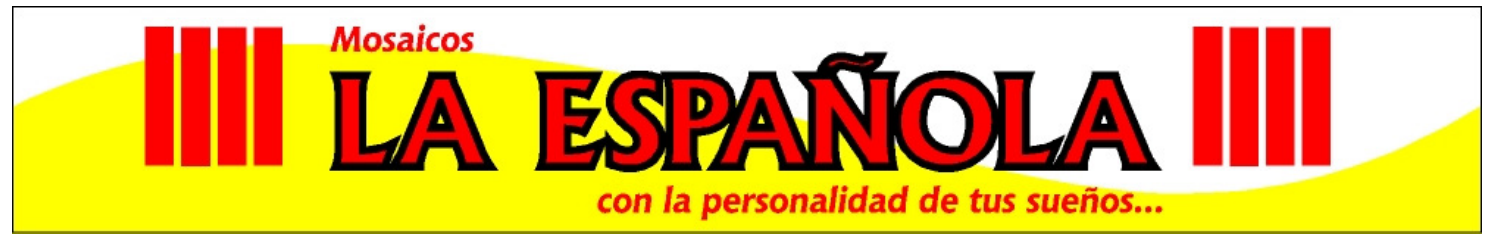




\section{Versión para dos tintas:}

\section{IIII

\subsubsection{Líneas comerciales.}

Una vez desarrollado el nuevo eslogan, todas las herramientas comunicacionales deben acercar este concepto al cliente, debiendo reforzar la nueva etapa por la que está transitando el mosaico. Esto obliga a generar nuevas líneas de productos, con novedosos y actuales diseños que acompañen esta evolución.

Como parte del desarrollo de la nueva imagen de marca, se detectó la necesidad de incorporar líneas de productos y desarrollar herramientas comunicacionales acordes a necesidades particulares de cada grupo de clientes, orientadas a satisfacer demandas puntuales según estilos de vida y tendencias de diseño actuales.

Para esto se crearon nuevas líneas de productos, entre las que destacaron las que se reflejan a continuación:

- Miró.

- Barcelona.

- Zaragoza.

- Mallorca.

- Ibiza.

Esas nuevas líneas de negocio serán desarrolladas en el futuro por La Española incorporando diseños exclusivos ${ }^{17}$ y particulares para adecuarlos a necesidades puntuales de determinados perfiles de consumidor.

\footnotetext{
${ }^{17}$ La exclusividad de un diseño alcanzada con la I+D de una empresa, debería estar protegida durante un período de tiempo que le permita el alcance de un desarrollo superador. ADAM SMITH, ya en 1776 reclamaba la necesidad de proteger a las innovaciones a través de patentes.
} 
A continuación se muestran los diseños generados para cada nueva línea de productos.

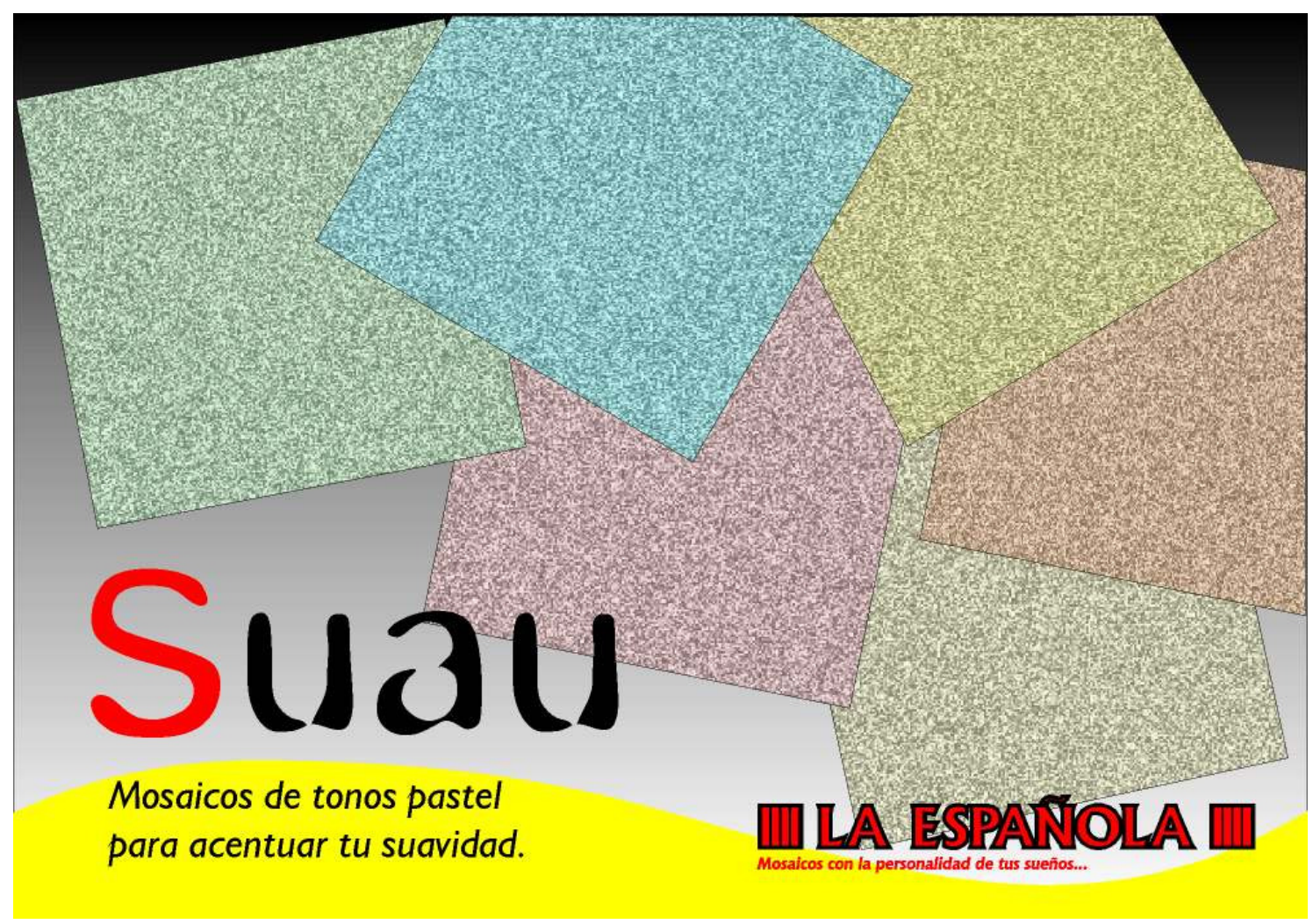



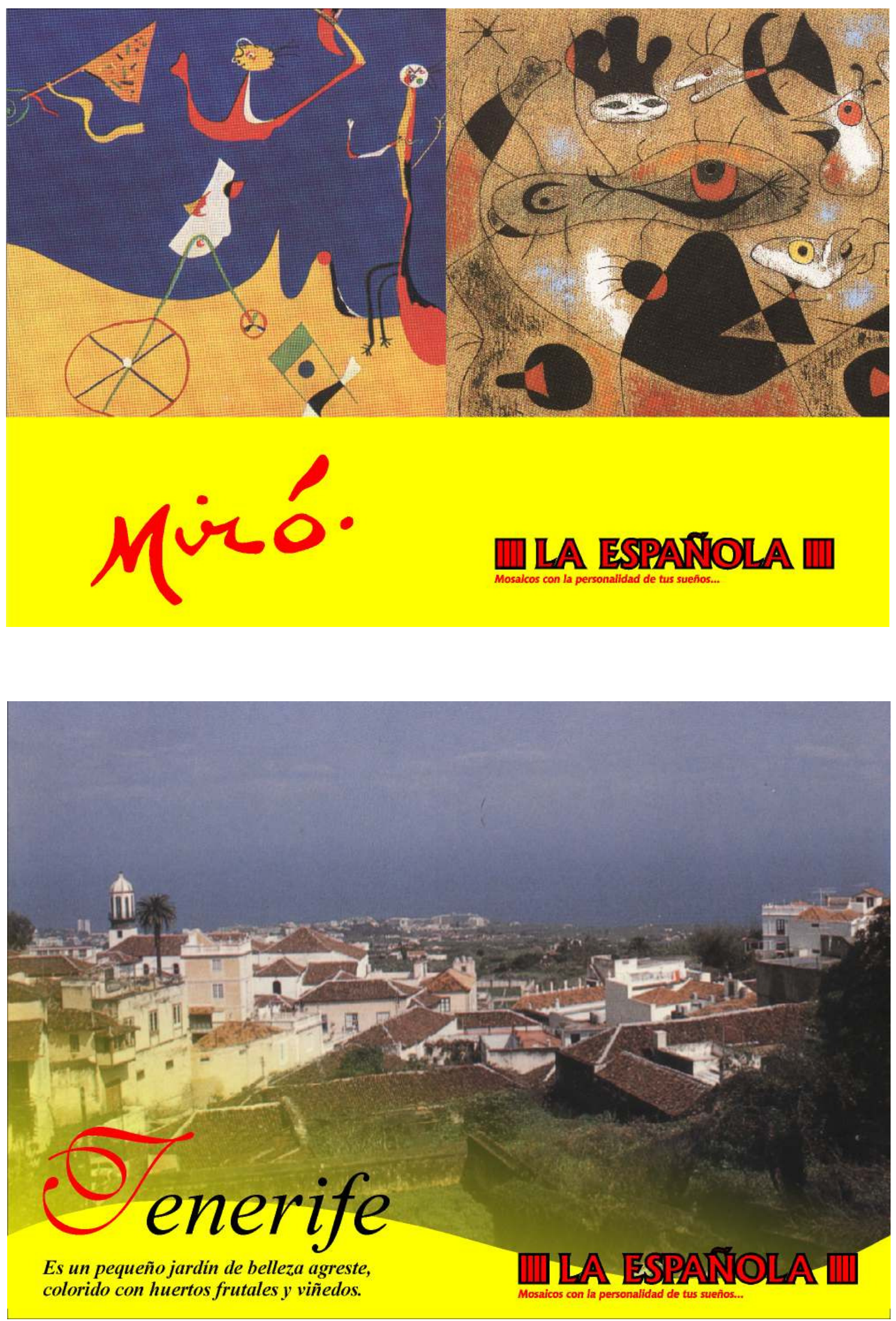

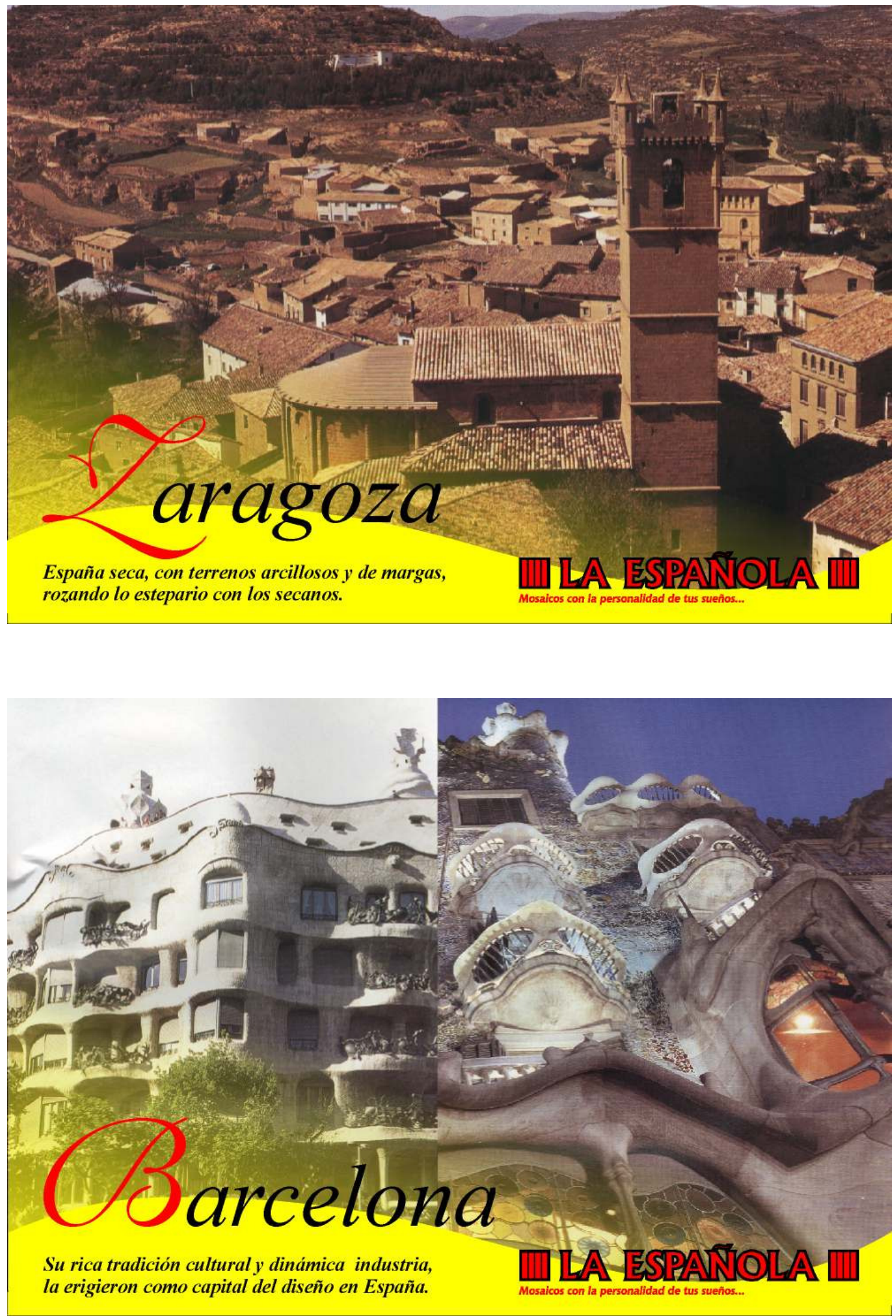

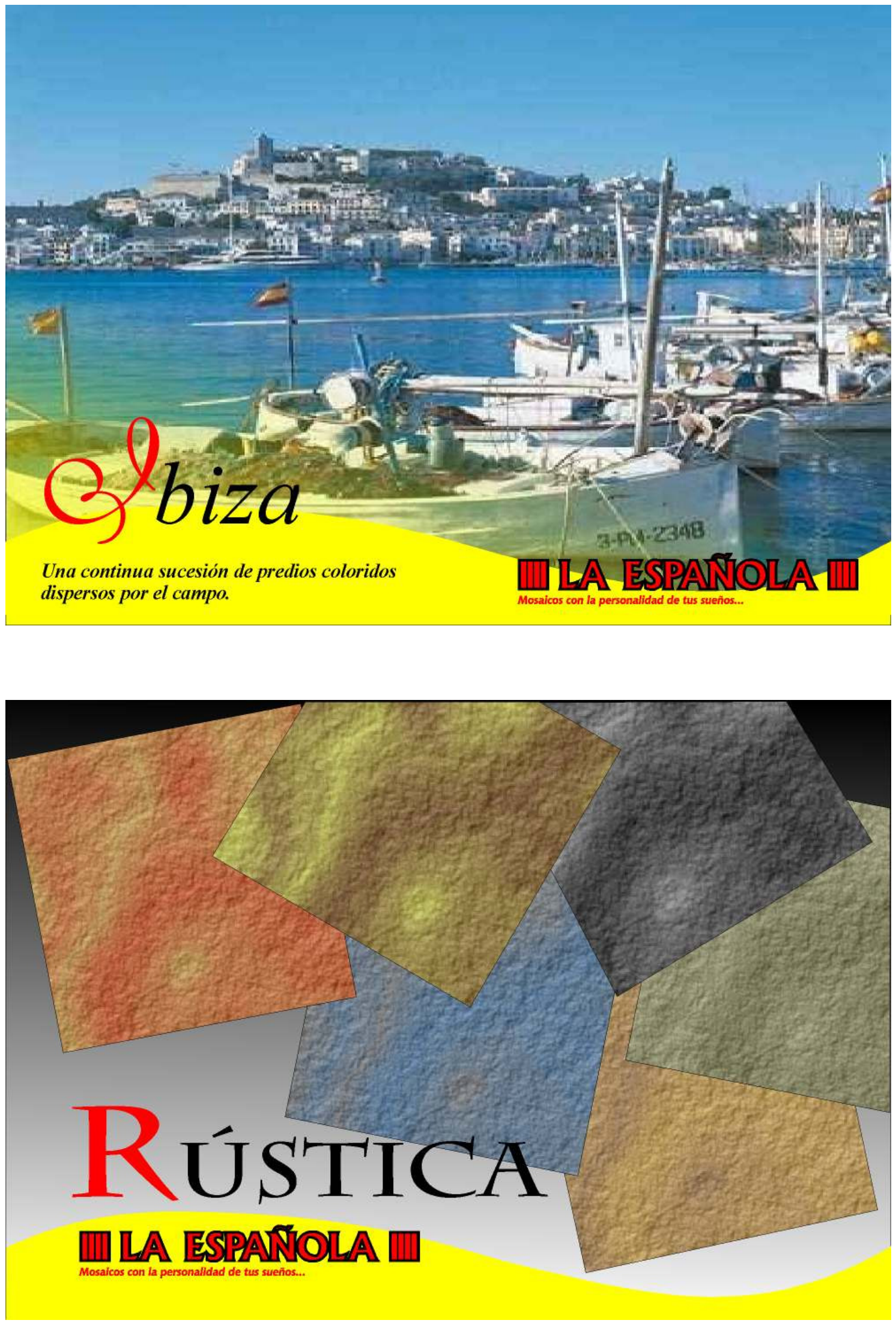

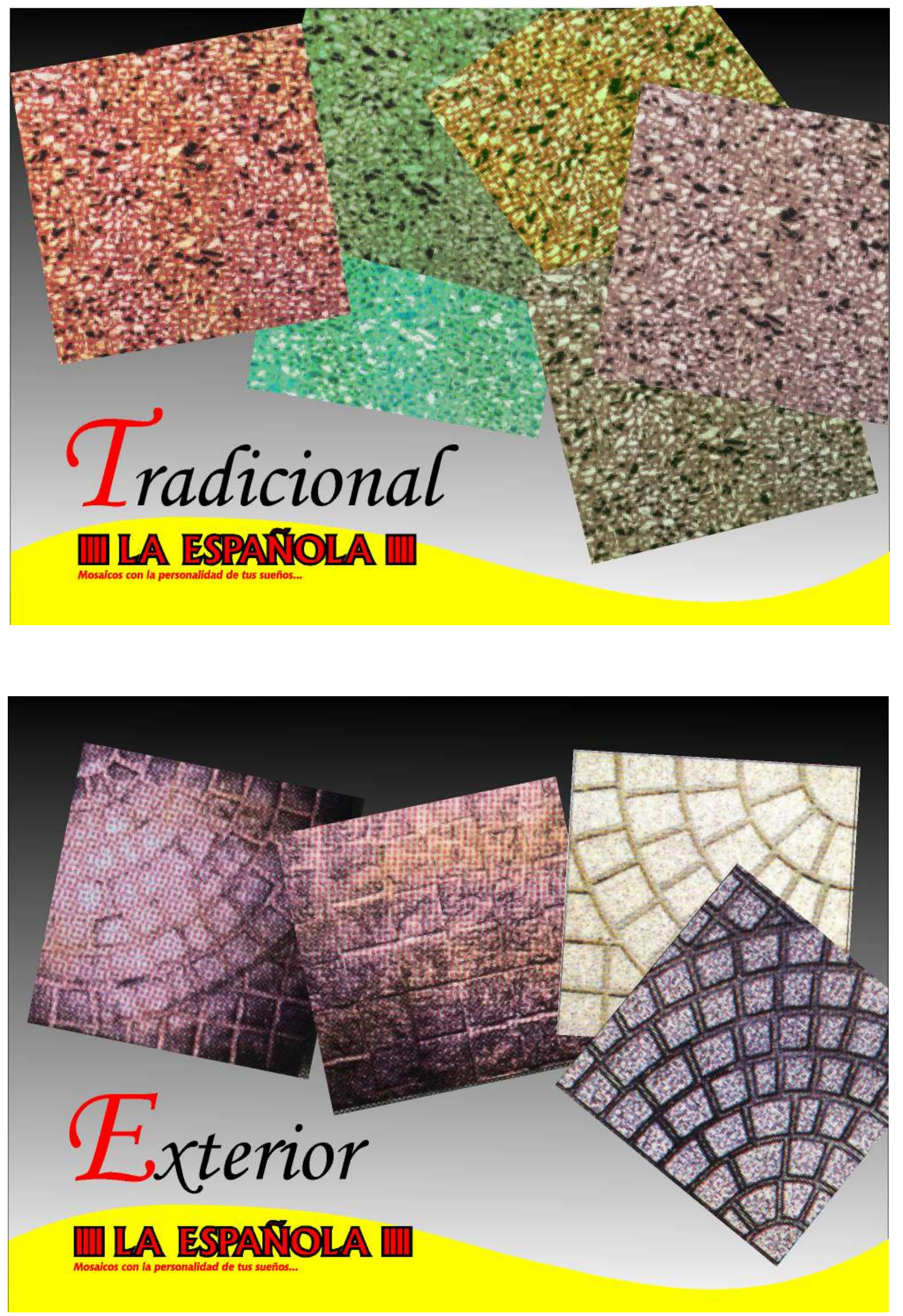


\subsubsection{Papelería, folletos y avisos publicitarios.}

Del diagnóstico preliminar y conocimiento inicial de la empresa, se detectó rápidamente la importante relación del producto ofrecido por La Española con el concepto de producto ampliado, que incluye no solamente de un elemento en un piso, sino también que este elemento debe incorporar además sensaciones y ventajas para el cliente como lo son los aspectos estéticos, de durabilidad, de confort, de estilo, de luminosidad, de resistencia, etc. Estas características del producto ampliado fueron hábilmente desarrolladas por el cerámico durante mucho tiempo, lo que provocó un importante revés para la industria del mosaico.

Por esto, algunos de los factores que se incluyeron en la nueva imagen son factores ya explotados por el cerámico y que históricamente no han sido bien aprovechados por el mosaico.

Algunos de estos factores son:

- Estética.

- Personalidad.

- Diseño.

Tradicionalmente, el mosaico se vio ligado indefectiblemente a la dureza-resistencia, pero no fue asociado en ningún momento con parámetros estéticos y de diseño. Esto es lo que se intenta reflotar y desarrollar en Mosaicos La Española.

Del análisis realizado de la empresa, se recopilaron los siguientes factores que determinan el cambio de imagen para La Española:

- Recesión natural del sector frente a otras alternativas mejor posicionadas en la actualidad, como por ejemplo los cerámicos.

- Estancamiento e el desarrollo de nuevas líneas de productos y no-adecuación a los requerimientos actuales del público objetivo.

- Obsolescencia en la oferta de productos. 
- Proceso de comunicación con el cliente anticuado y obsoleto, manteniendo los conceptos antiguos del mosaico como mensaje hacia el cliente.

Estos puntos requieren un cambio importante hacia los conceptos estéticos, y de diseño requeridos por el público tanto masivo, como profesional e industrial.

Para esto es imprescindible:

- Incorporar a la mujer como compradora y dirigir las herramientas comunicacionales hacia ella como protagonista de la decisión.

- Reajustar el concepto del mosaico, más que como un elemento de construcción, también como un elemento decorativo, incorporando nuevos diseños y formas. De esta forma, podemos hacer convivir las ventajas tradicionales (durabilidad, fortaleza, etc.). Con nuevas ventajas mucho más actuales y orientadas hacia lo estético y también más atractivas para nuestro nuevo comprador (la mujer).

Asimismo, La Española necesita un cambio de imagen como empresa. Dada su larga trayectoria, la imagen de La Española se había estancado sin muchas posibilidades de actualización.

Por otra parte, si se espera que el cambio en la línea de productos aumente las ventas entre los clientes actuales, éstos deben saber que se les ofrece ese producto adicional. Es decir, que también deberán realizarse anuncios referidos a éste, en los medios de comunicación.

Si se busca que la innovación de un producto atraiga a nuevos clientes, la introducción deberá acompañarse de algún esfuerzo promocional. 
Diseño de papelería:

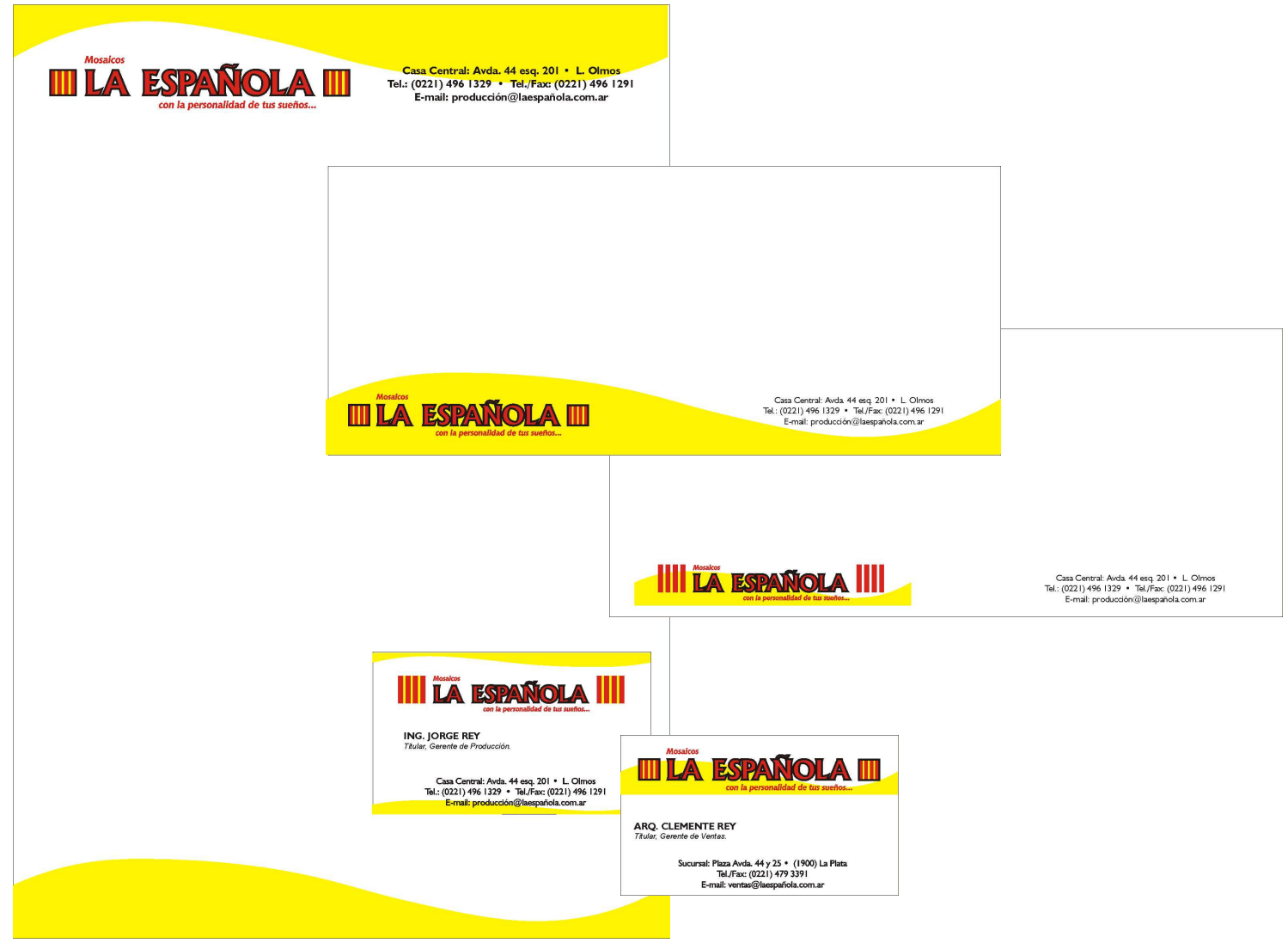




\subsubsection{Aplicaciones del eslogan principal y secundarios.}

Durante el proceso de aplicación del slogan principal se trabajó en la aplicación de mensajes paralelos que reflejaran el nuevo concepto de la empresa. Así, además de la aplicación del slogan “con la personalidad de tus sueños...” Seleccionado por la empresa en su discurso de marca, se reflejaron otros mensajes directos en función de la aplicación de los elementos publicitarios, como son:

- Te proponemos un cambio.

- Personalidad.

- Estilo.

Estos mensajes directos, pretendían concentrar en un mensaje simple el proceso de reencauzamiento buscado.

Así mismo, se mantuvo la idea de no perder la trayectoria y las bondades del mosaico. Para esto, se tuvieron en cuenta tanto los factores tradicionales, como los de renovación de imagen.

\section{Tradicionales:}

- Resistencia.

- Solidez.

- Calidez.

\section{Novedosos:}

- Diseño.

- Sueños y estética.

- Belleza $^{18}$.

\footnotetext{
${ }^{18}$ El punto "Belleza", refiere a la cualidad percibida por el mercado y no a la subjetividad del diseñador o de la empresa.

"Muchas personas piensan que existe la belleza absoluta y sostienen furiosamente que una cierta cosa es bella y otra es fea. Se enojan cuando uno no comprende aquello que ellos intentan decir o mostrar y están convencidos que la obra de arte sea sobre todo belleza espiritual. El diseñador cuando proyecta algo, no se preocupa de hacer una cosa bella, pero se preocupa que la forma sea coherente a la función, comprendida aquella psicológica”. (MUNARI, BRUNO, Artista e Designer, Latterza, Bari 1971).
} 
A continuación se presentan los diseños realizados para cubrir los elementos publicitarios en los diferentes segmentos de mercado (Masivo, Profesional e Industrial) necesarios en este proceso de transformación de Mosaicos La Española.

\section{Guía telefónica - Año 2002:}

\begin{tabular}{|c|c|c|c|}
\hline & Planta de silos 2 Q & Olmos - Tel: & $7 \times 2$ mL Llata - \\
\hline esta pdigina & 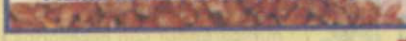 & & MOTORSHOP- \\
\hline $.0221423-0000$ & & & Suzuki-Honda-Guerier-Gilera y Màs \\
\hline & $\begin{array}{l}\text { MONTACARGAS } \\
\text { REPARACIONES } Y\end{array}$ & & $0221483-0083$ \\
\hline & MANTENIMIENTO & & N CLASS \\
\hline 54377 & LA PLATA (0221) & & $\begin{array}{l}\text { Concesionarie Oficial Honda } \\
\text { e-malliopendaseway.com.ar }\end{array}$ \\
\hline $0221464-3771$ & ASCENSORES CECCONATO SRL- & om. & pho Centenario 2621 eq9 506 \\
\hline ALARMAS & $\begin{array}{l}\text { Venta-Montaje y Martenimiento } \\
\text { wWw. ascensorescecconato.com. ar }\end{array}$ & $\begin{array}{l}25 \text { Ne103- La Plata } \\
\text { 21 } 496-1291\end{array}$ & $\begin{array}{l}\text { EREZ - MONDIAL. KAWASAKI } \\
\text { Creditos*N } 1 \text { en Ventas y Servicios }\end{array}$ \\
\hline & $24 N^{2}=048 \mathrm{esc} 7 \mathrm{~T}$ & & $0221427-1472$ \\
\hline PES - FABA:CACOCH Y & $106 \mathrm{Ni}$ & & $\begin{array}{l}\text { BERISSO (0221) } \\
\text { MOTOMANIA - BERI SRL- }\end{array}$ \\
\hline & MONIAUES INDUSTRIALES & 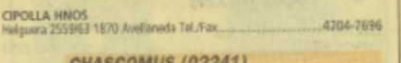 & $\begin{array}{l}\text { Concesionario Oficial Kawasaki } \\
\text { Motos - Jet Ski - Ciclomotores }\end{array}$ \\
\hline 02214235067 & & $\begin{array}{l}\text { CHASCOMUS (02241) } \\
\text { Mes morano }\end{array}$ & Mondial-Scooter-Peugeot $461-2550$ \\
\hline & 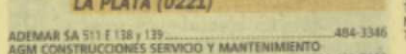 & 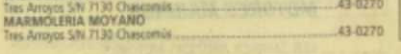 & $0221464-4117$ \\
\hline $\begin{array}{l}\text { DELLTA SRL } \\
\text { NIACARGAS } \\
\text {-AMIAS }\end{array}$ & 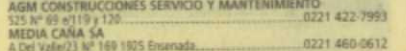 & CORONEL BRANDSEN (02223) & CHASCOMUS (02241) \\
\hline $\begin{array}{l}422 \cdot 755778 \\
049\end{array}$ & 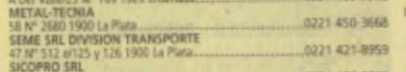 & $\begin{array}{l}\text { UA wOUSTRAL LE HES TE } \\
\text { GRAL BELGRANO (02243) }\end{array}$ & $\begin{array}{l}\text { ALFonsin Motos } \\
\text { Utilice nuestro cupón de descuento }\end{array}$ \\
\hline & 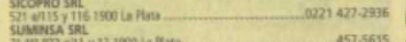 & $\begin{array}{l}\text { EL GALLEGO } \\
\text { Av Lbertad } 1221 \text { ma Gral Beigrano. } 0224345-4686\end{array}$ & 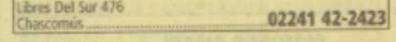 \\
\hline $0221453-3685$ & NW & 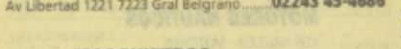 & Motos latma \\
\hline$=0 \times 0.0214800160$ & BERISSO (0221) & MOSQUITEROS & 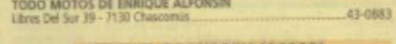 \\
\hline & 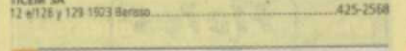 & 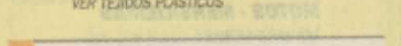 & CORONEL BRANDSEN (02223) \\
\hline esc 1 ? & mosaicos & MOTOBOMBAS & 262. \\
\hline Instatació & 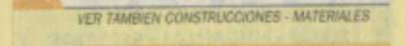 & & MOTOCICLETAS Y \\
\hline Montacargas & LA PLATA (0221) & AVELLANEDA (03482) & REPARACIONES \\
\hline 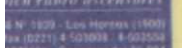 & Mosaicos Cana & 249211 & A PLATA $(0221)$ \\
\hline thentic & Hnos. S.H. & $\begin{array}{l}\text { MOTOCICLETAS Y } \\
\text { CICLOMOTORES }\end{array}$ & 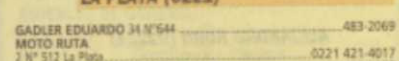 \\
\hline 0221489.6371 & $\begin{array}{l}\text { FÁBRICACION AÚTOMATICA } \\
\text { DE MOSAICOS Y MARMOLERIA }\end{array}$ & LA PLATA (0221) & 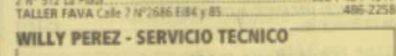 \\
\hline $022169 \mathrm{~mm}$ & MESADAS - ESCALERAS & AKASHIS & Todas las Marcas Garantizadas \\
\hline 111) & $\begin{array}{l}24 \mathrm{~N}^{\circ} 665 \text { e } 45 \text { y } 46 \text { - }(1900) \text { La Plata } \\
\text { Tel./Fax }(0221) 479-5148\end{array}$ & Vea. y Reparadion Motos * $422-5701$ & $0221427 \cdot 1472$ \\
\hline IMP & & $0221422-2587$ & BERISSO (0221) \\
\hline $\begin{array}{l}\text { Irjulicos } \\
\text { bescaleras }\end{array}$ & - & 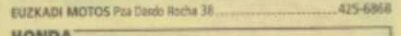 & MOTOMANIA - BERI SRL- \\
\hline 0114207.8123 & $\begin{array}{l}\text { DI DOMENICANTONIO y CIA. S. A. } \\
\text { Z Fabricación de Mosaicos }\end{array}$ & Otero Motor-Honda-Mondial & $\begin{array}{l}\text { Concesionario Oficial Kawasaki } \\
\text { Motos - Jet Ski-Ciclomotores }\end{array}$ \\
\hline
\end{tabular}




\section{Detalle:}

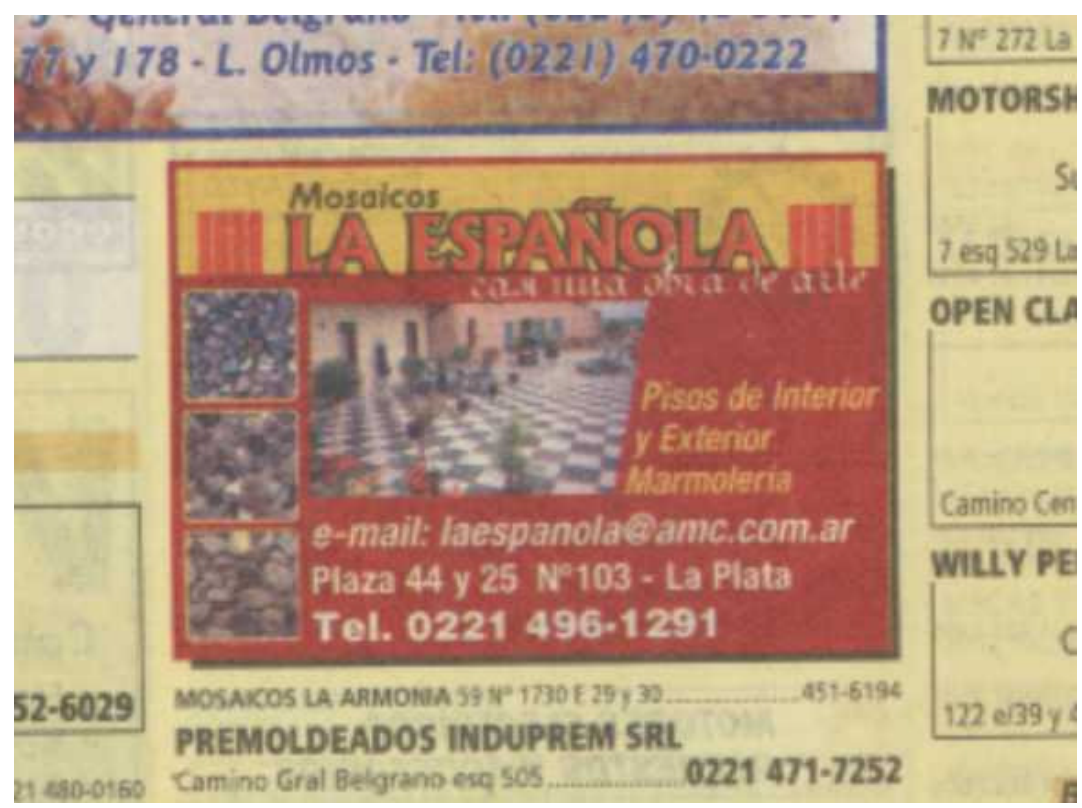


Avisos publicitarios:

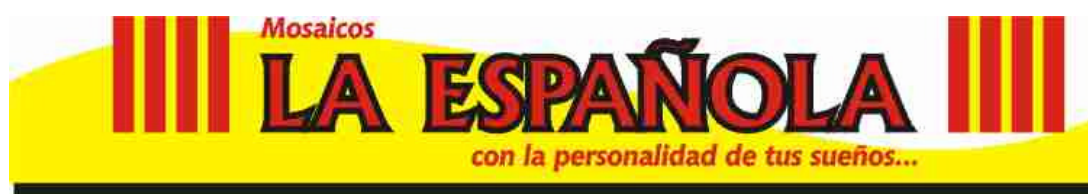

En La Plata: Plaza 19 de Noviembre No103 (44 y 25) Tel: 479.3391 y en L. Olmos: Av. 44 y 201 Tel: $496-2066 / 1291$

\section{Nuevas \\ EDNEEPTロS}

\section{EN Masaicas}

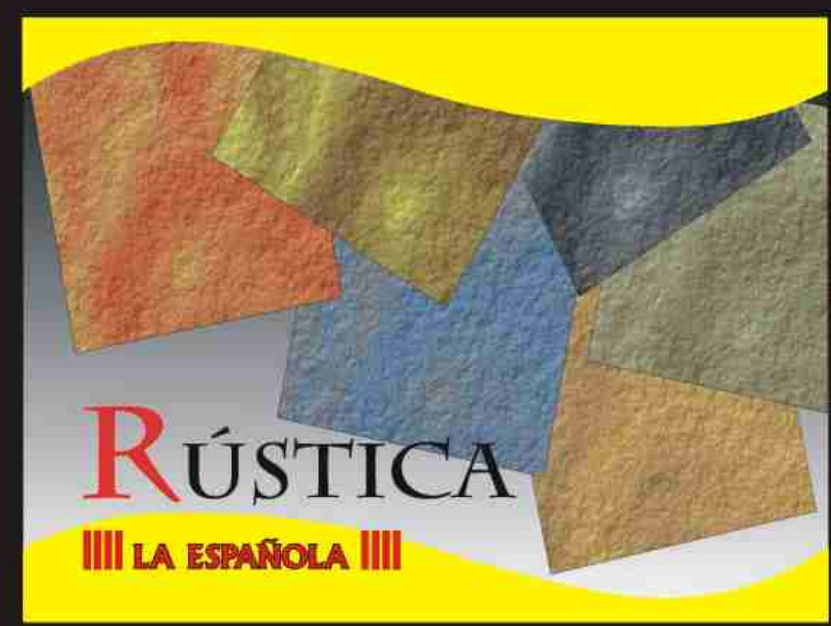

Cualquiera sea su espacio, LA ESPAÑOLA sabe como convertirlo en un espacio vital, personalizando todo aquello que cualquier persona exigente aprecia: funcionalidad, estilo, calidad, $y$ un valor que perdura en el tiempo.

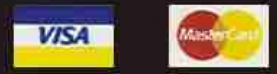




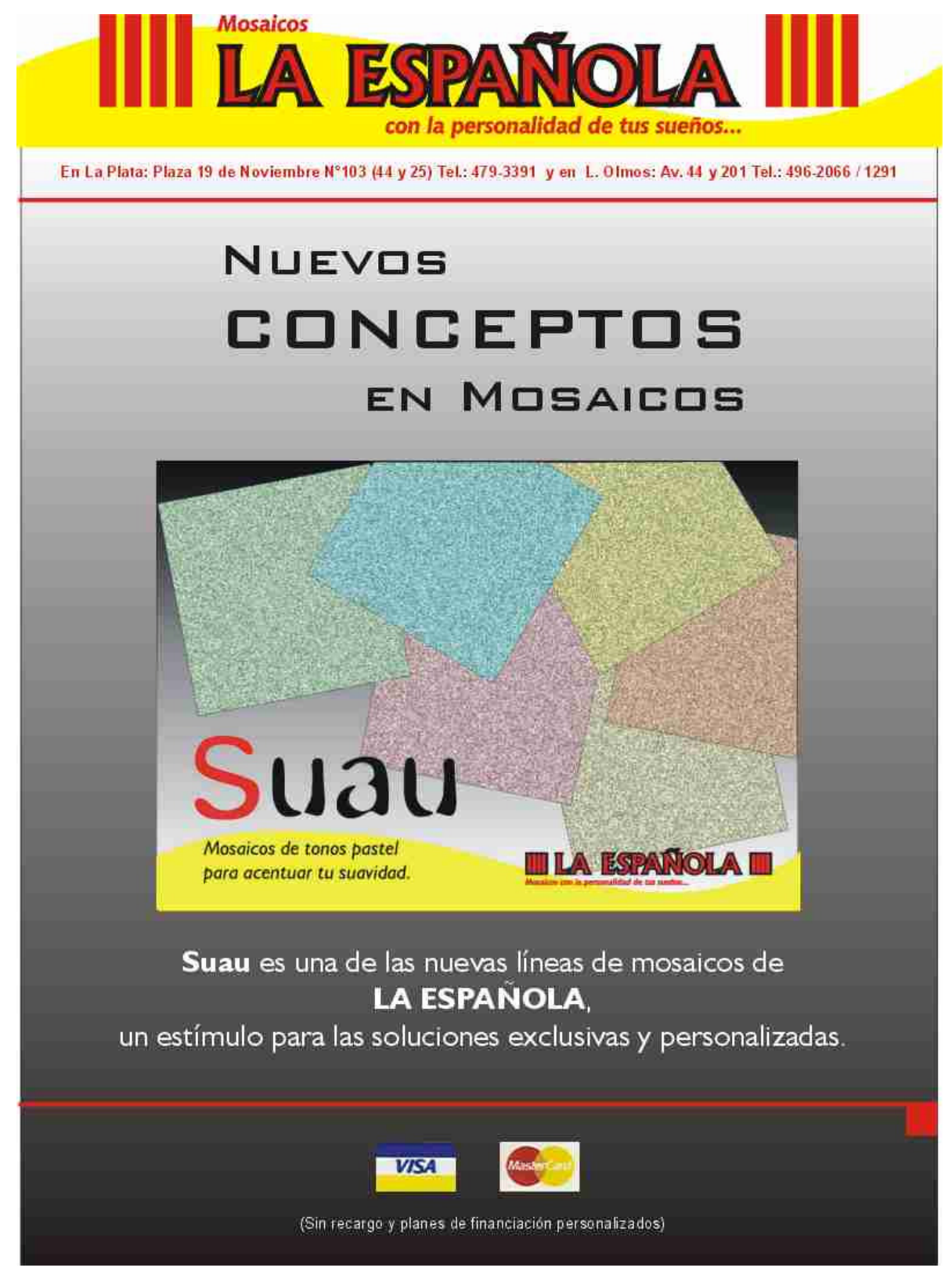




\subsubsection{Rediseño del punto de ventas.}

Según los conceptos que se desarrollaron para toda la nueva imagen institucional, se trabajó en el diseño de dos propuestas para la remodelación del punto de venta masivo ubicado en calle 25 esquina 44.

En la primera propuesta, se desarrolla un concepto de exposición de los productos, como si fueran obras de arte. Un monolocal, donde se previó una circulación interna alrededor de dos expositores distribuidos centralmente.

En la segunda propuesta de diseño interior, se buscó recrear un ambiente cálido, sociable, con una mesa oval central para butacas altas, y un sillón con expositor para el exterior. El funcionamiento de esta propuesta, sustenta sobre la base de la comodidad del cliente y la apertura del vendedor para acompañarlo desde un mismo nivel en la búsqueda del producto ideal. Se previó también el apoyo de un equipo informático, para que el cliente pueda realizar una visita virtual del catálogo y así ver y escoger las diferentes combinaciones de mosaicos.

Seguidamente, se pueden evaluar las propuestas que se proyectaron.

\section{Exterior del punto de ventas:}

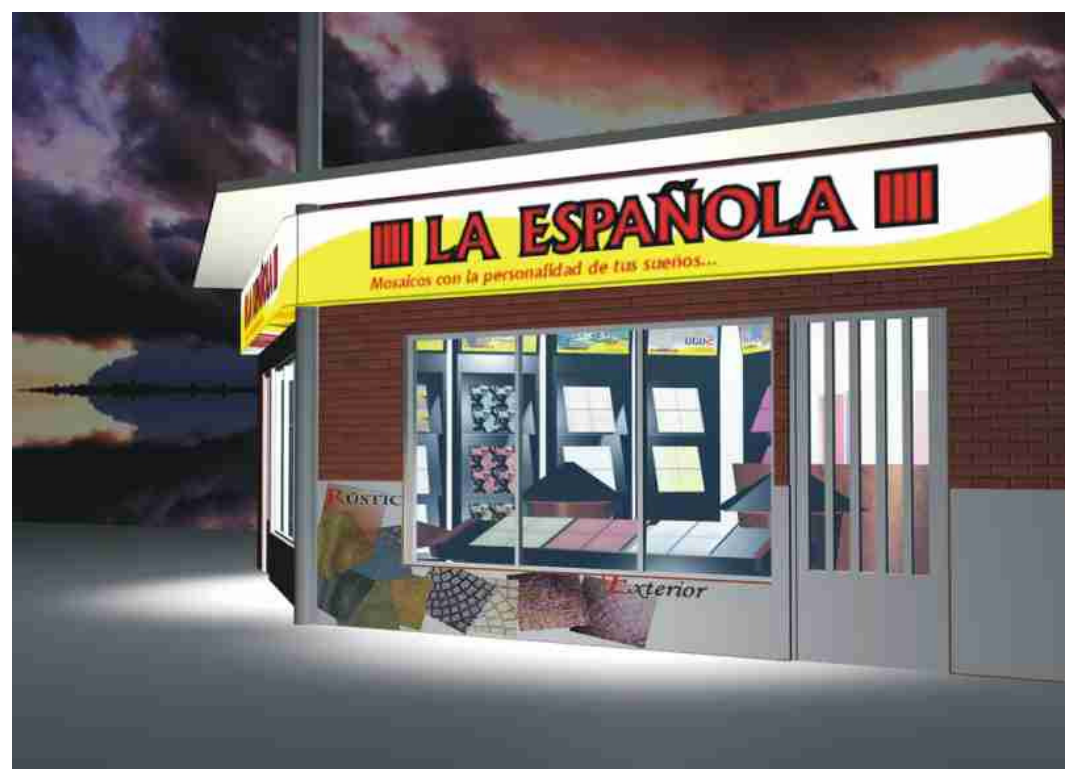



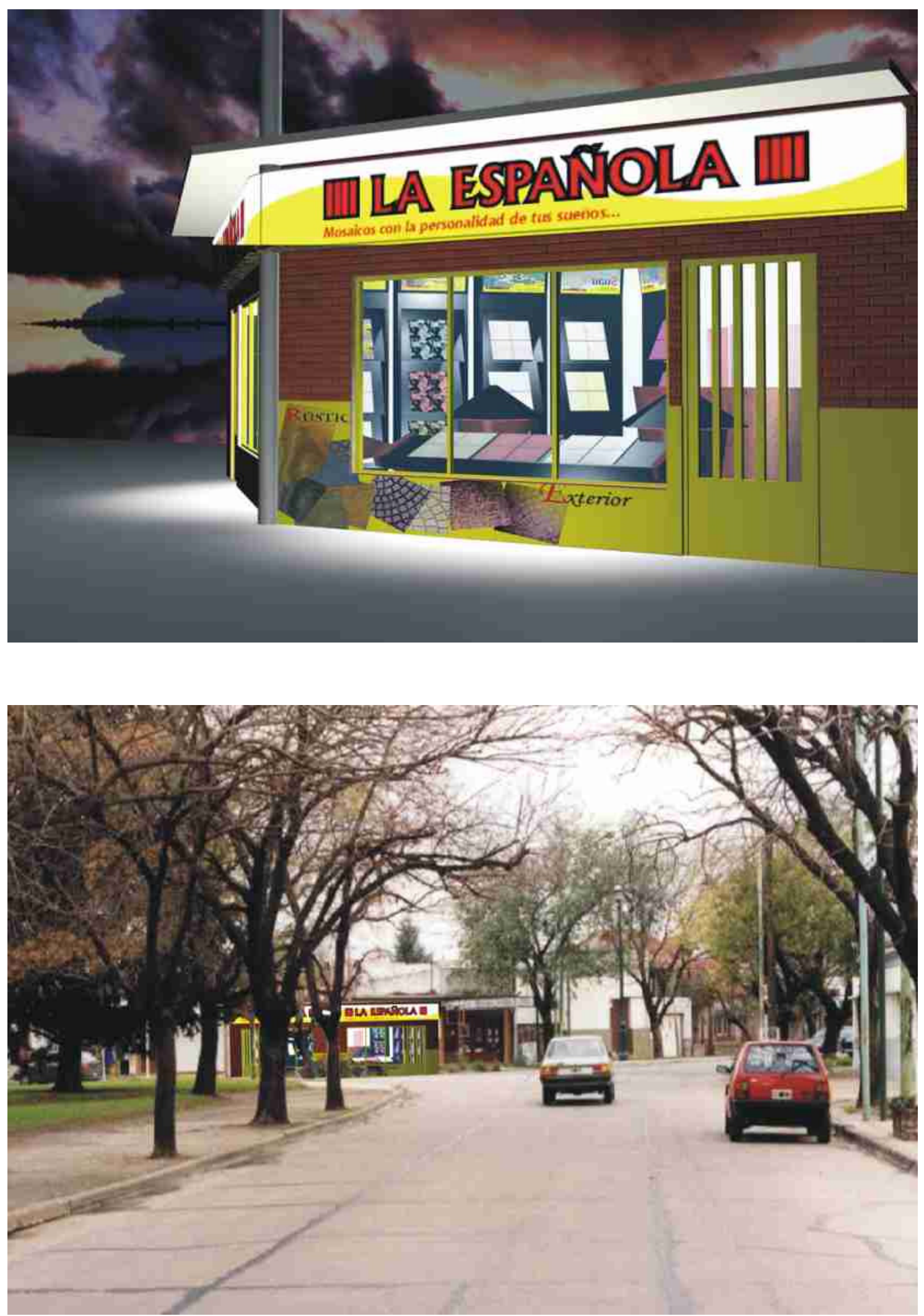

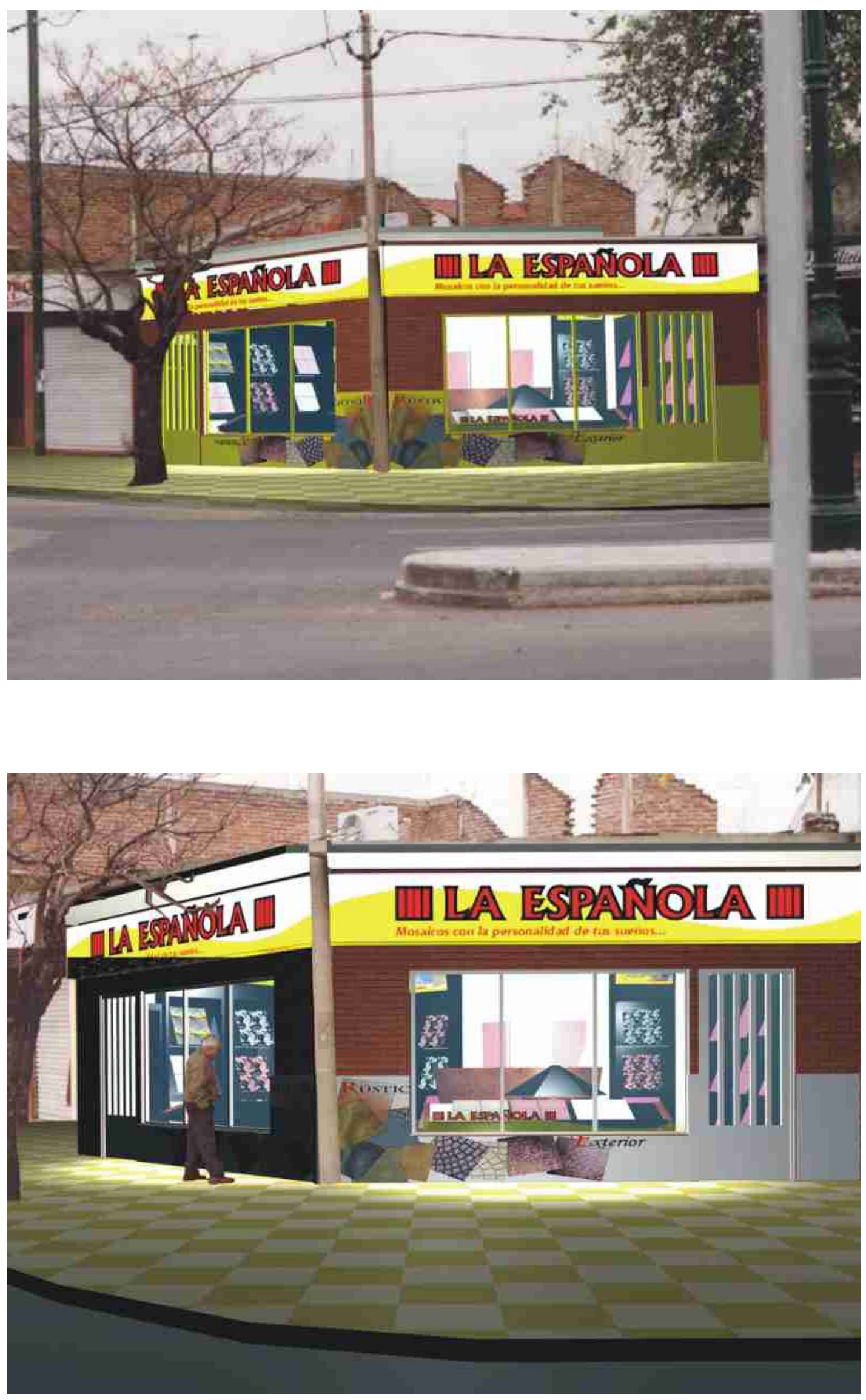


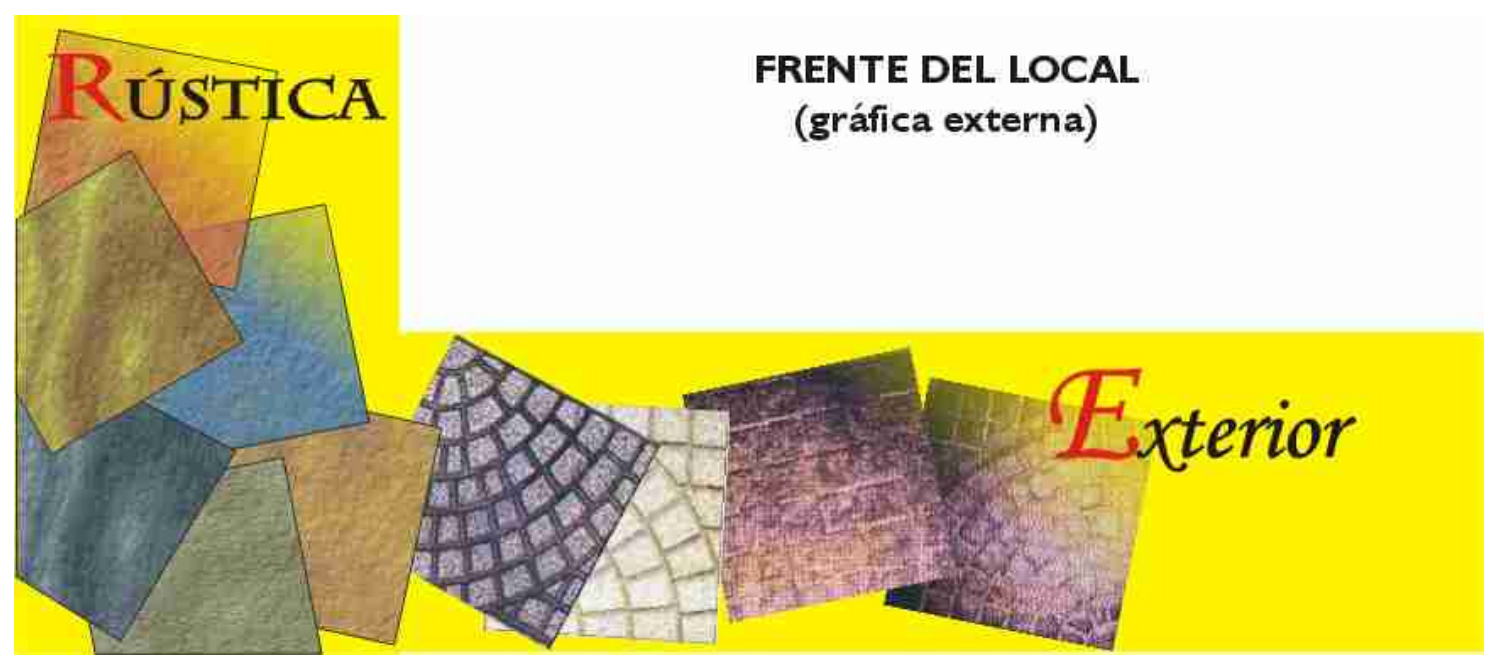

\section{FRENTE DEL LOCAL}

(gráfica externa)

\section{Tradicionaf}

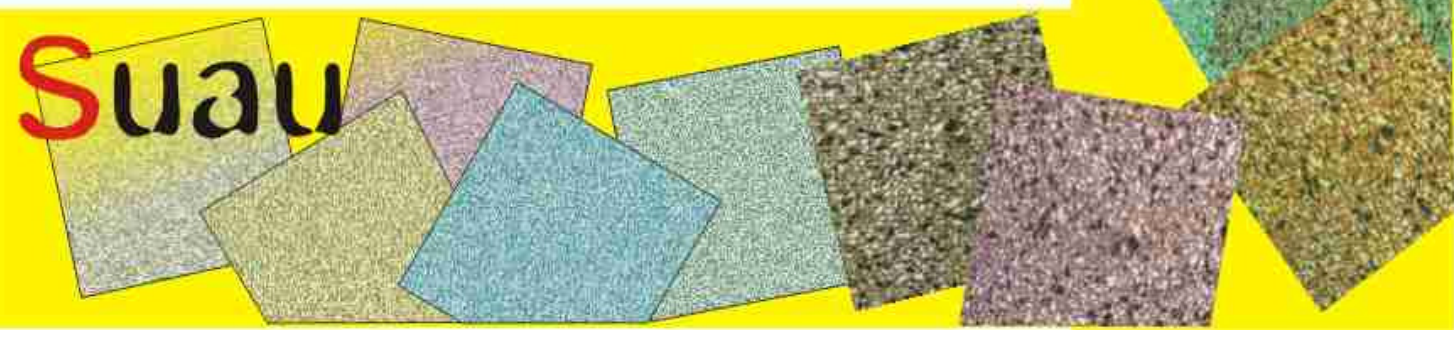

FRENTE DEL LOCAL

(gráfica externa)

\section{Tradicional}

\section{IILA ESTANIOLA I}




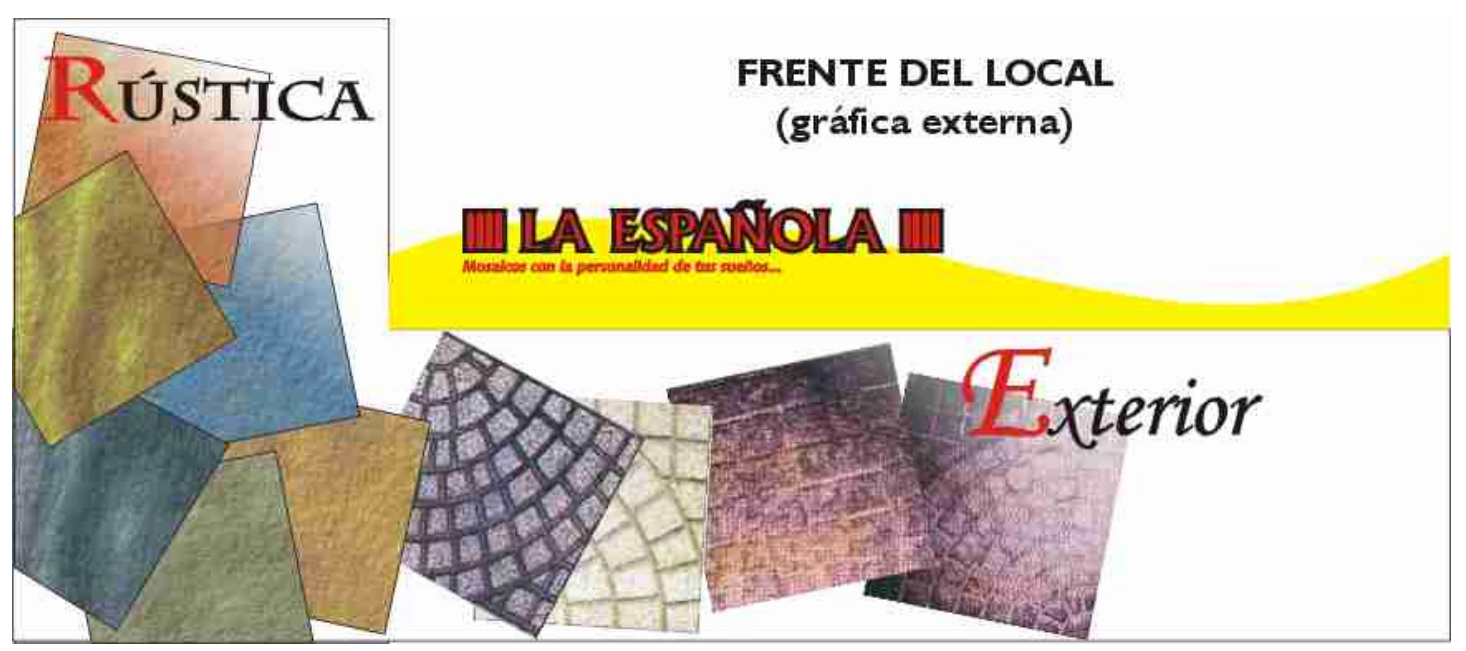




\section{Propuesta 1:}
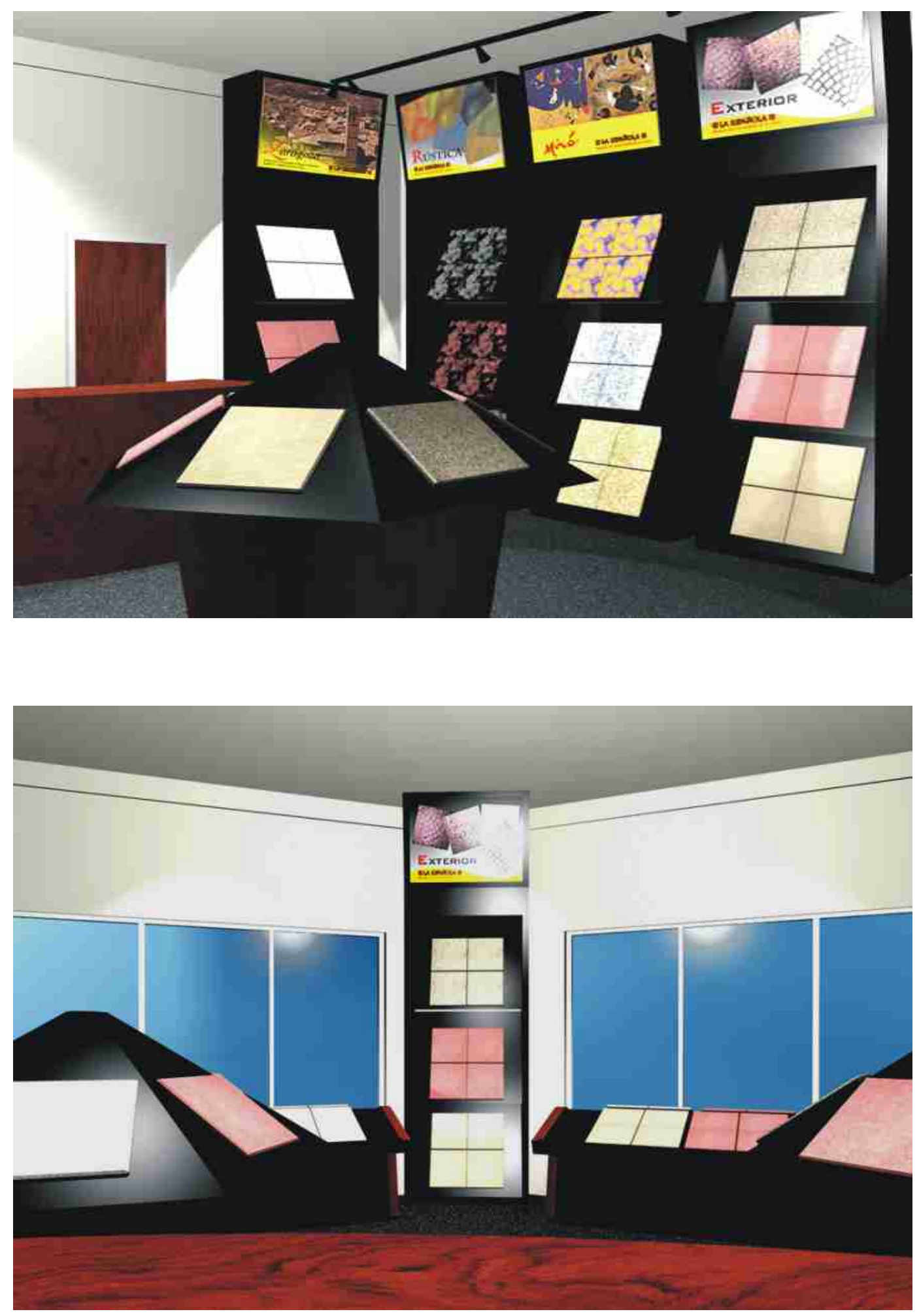

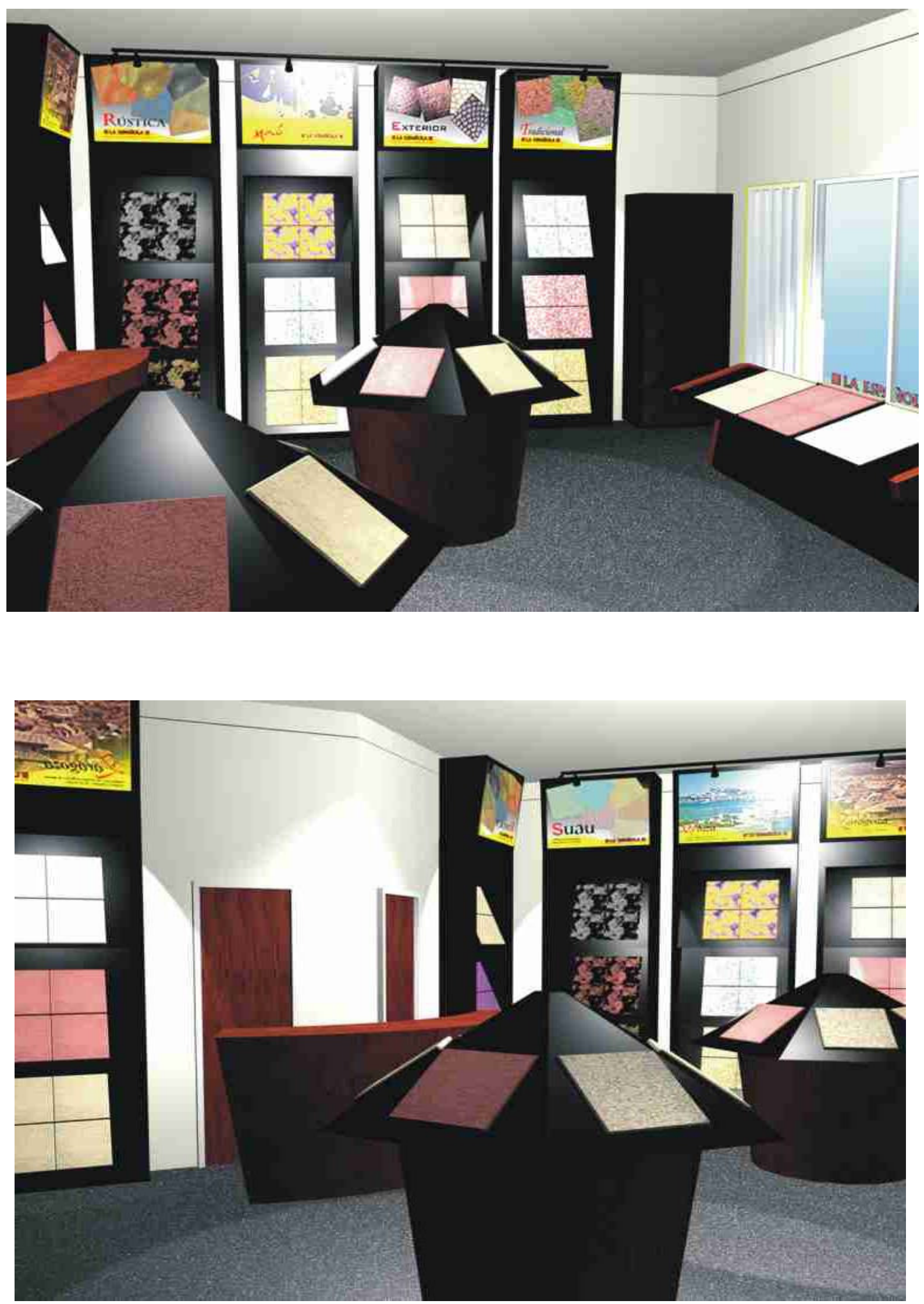
Planta del local comercial:

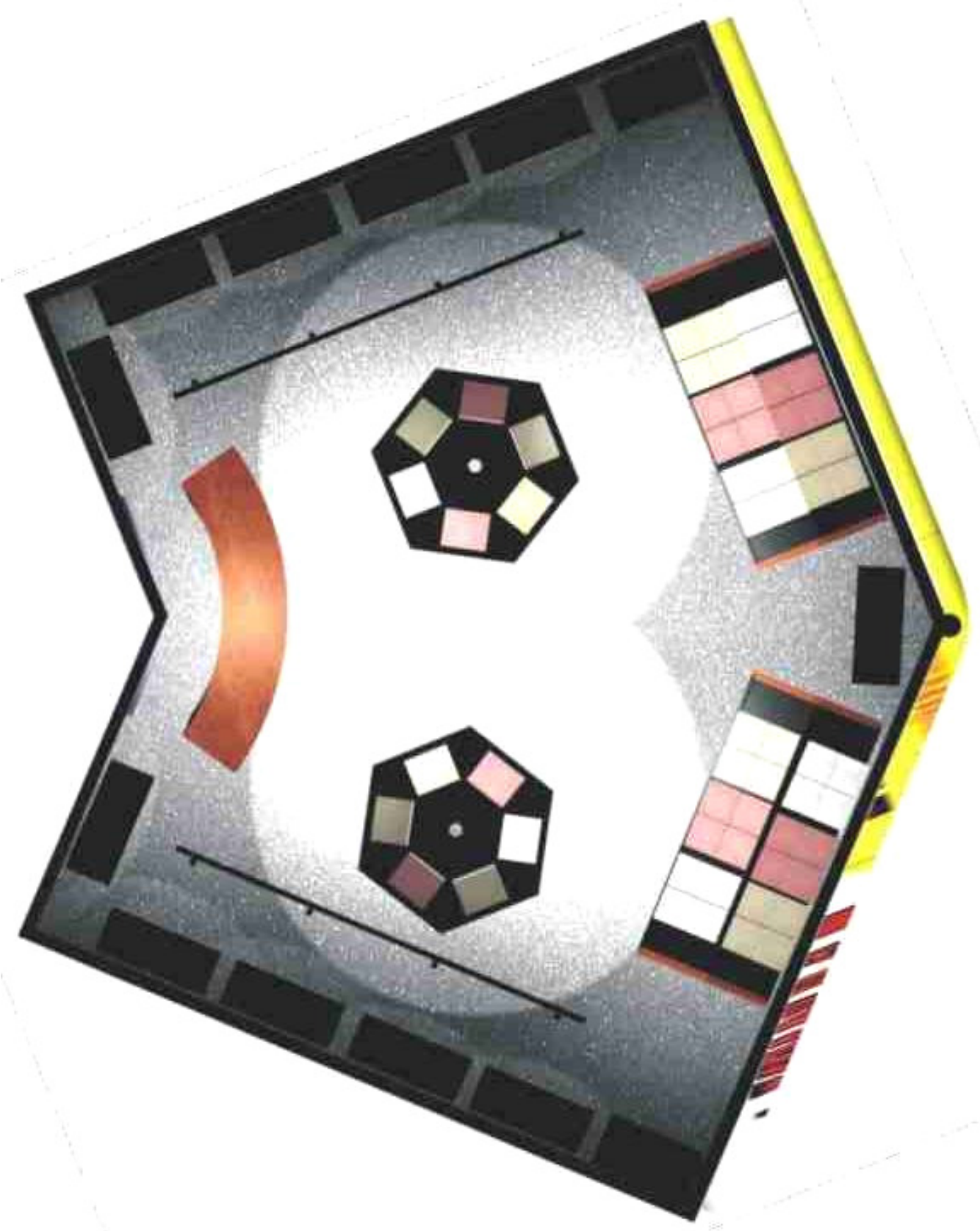




\section{Propuesta 2:}
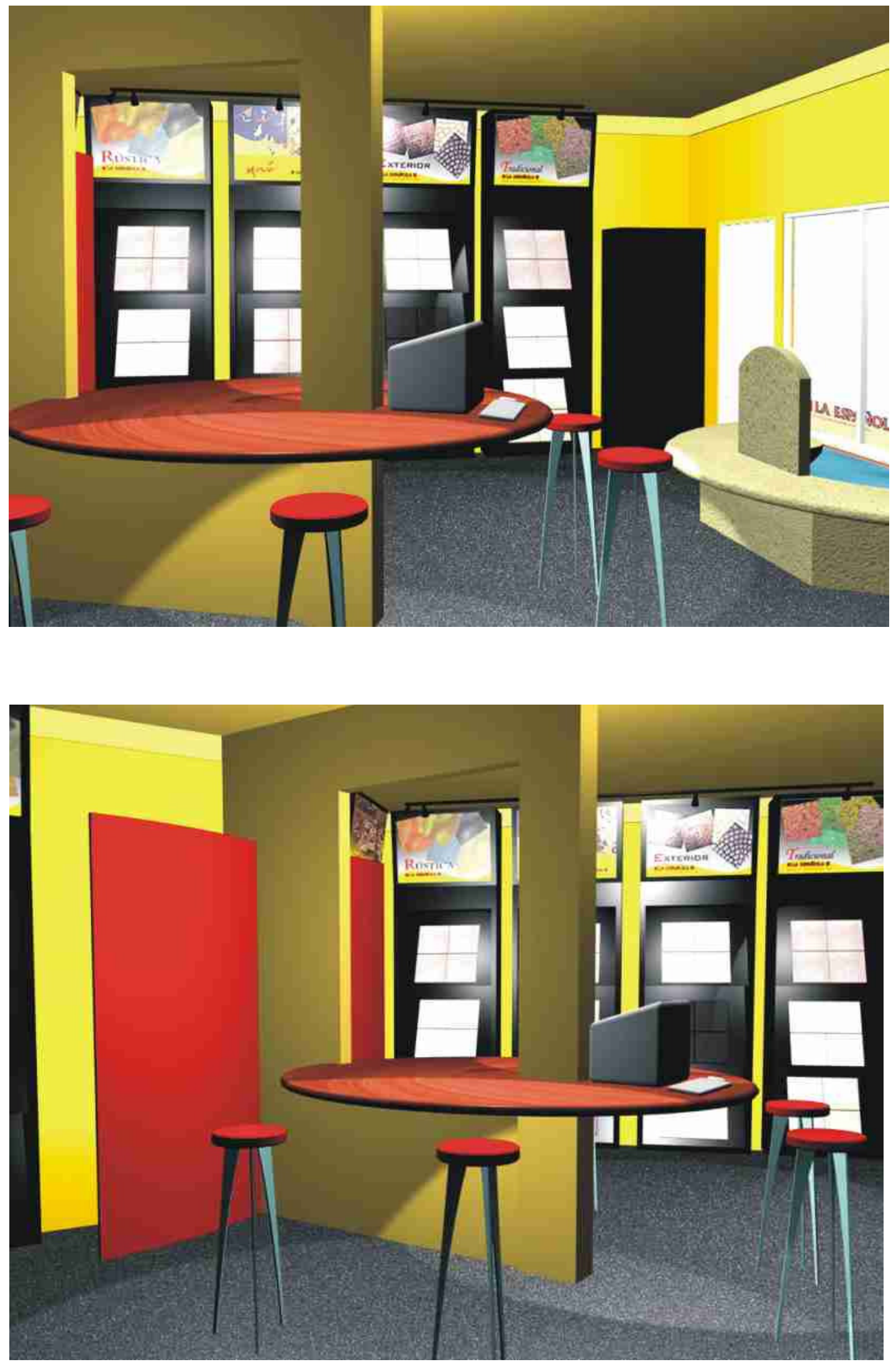

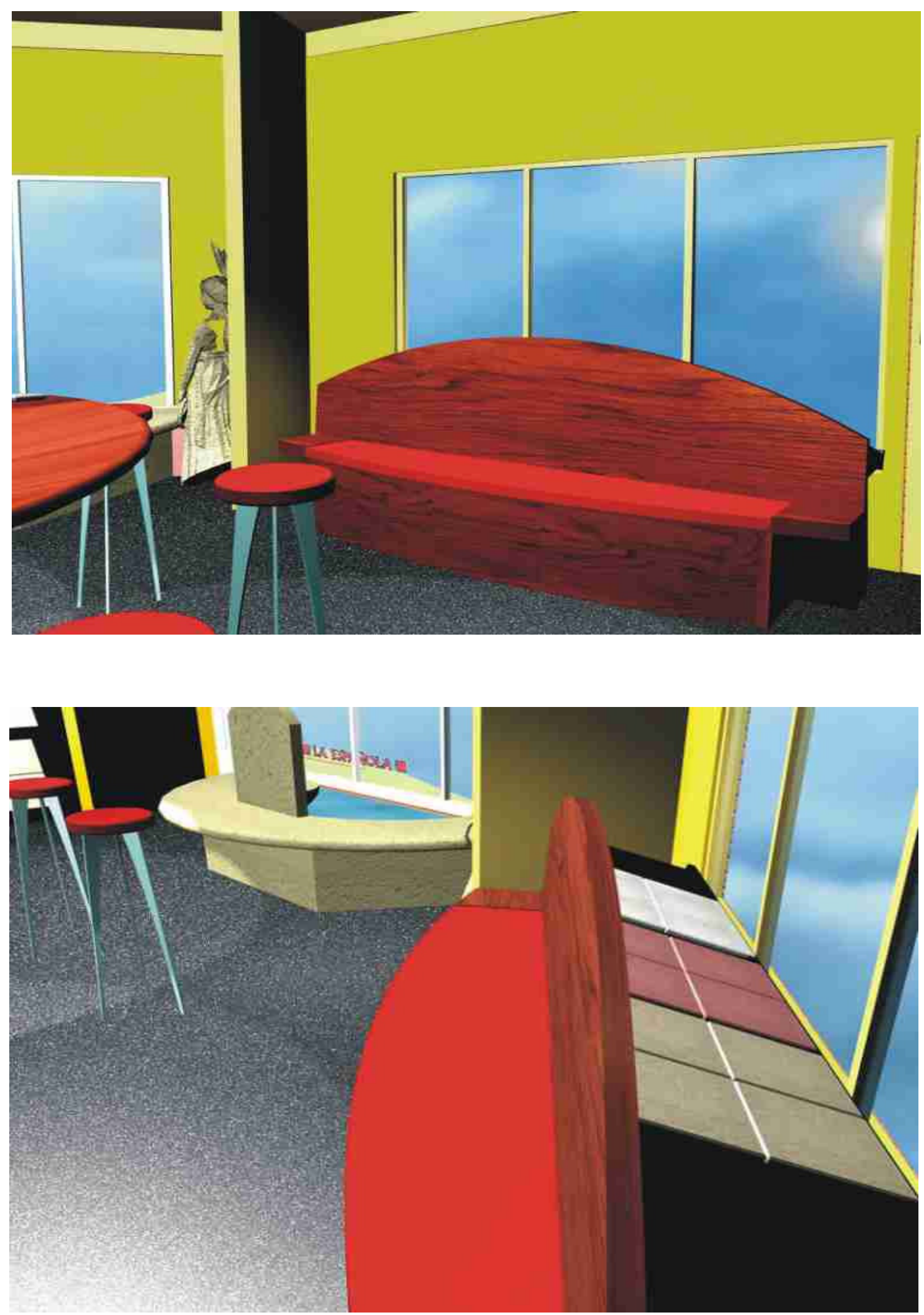


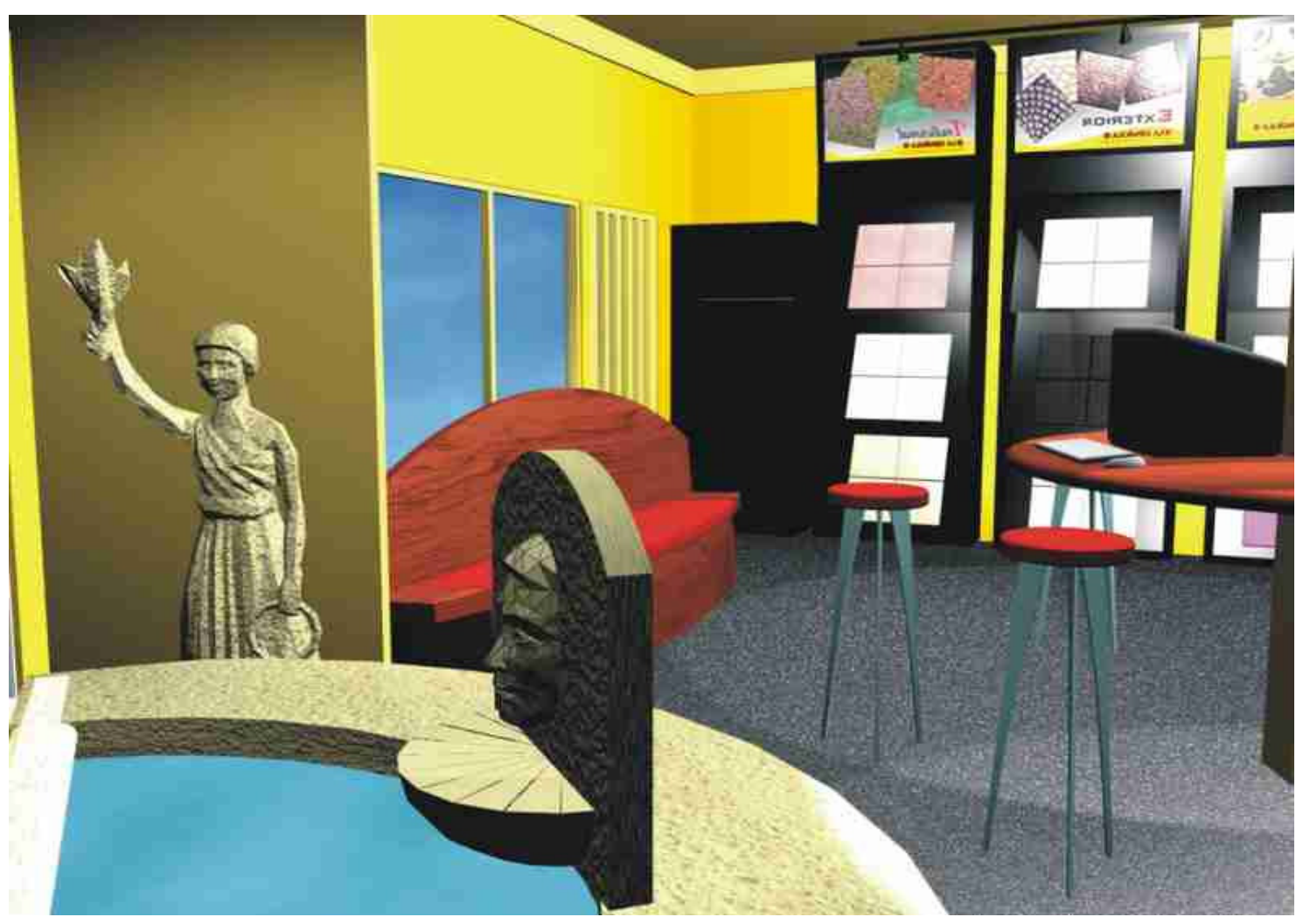


Planta del local comercial:

\subsection{5.}

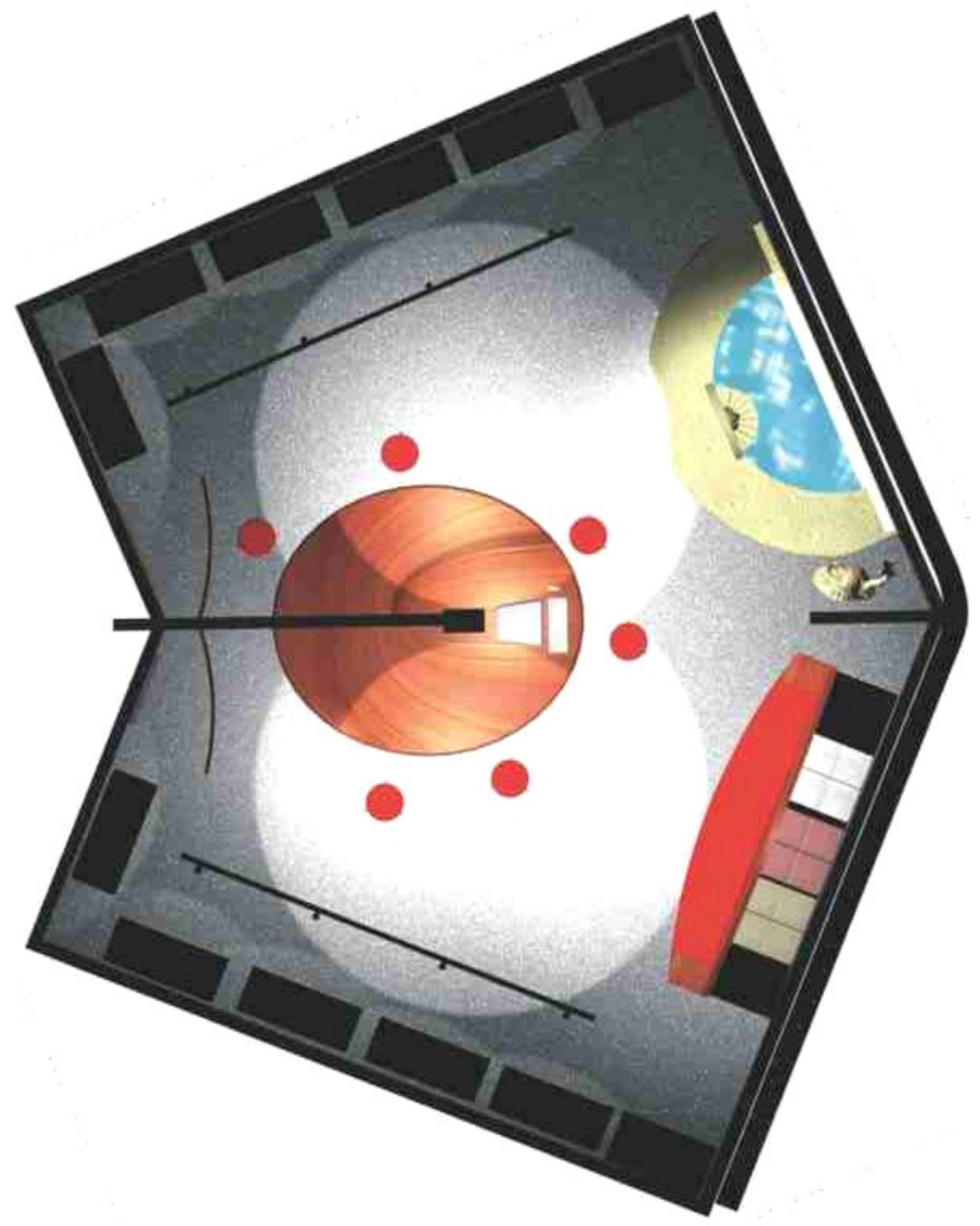




\subsubsection{Pagina Web institucional.}

Es importante conceptualizar a esta herramienta, como una ayuda para promover a la empresa. Se ha descubierto que las páginas Web son una fuente constante de ganancias y nuevos clientes.

Esta página deberá ser sencilla, para poder descargarse con rapidez. Además de cumplimentar los requisitos para apuntar a los navegantes meta, tendrá que contar con un catálogo interactivo de todos los modelos de mosaicos, ordenados por líneas comerciales.

Asimismo, como una pagina Web no es un objeto estático, será necesario actualizarla, por lo menos una vez al año.

En este sitio, además de posicionar a La Española en Internet y ofrecer en línea el catalogo de productos, deberán plantearse los mecanismos para obtener una lista de las direcciones de correo electrónico de las personas que se conectan a éste, para enviarles material promocional en forma regular.

Existen varios niveles de beneficios para la compañía, si se cuenta con una página Web. Ésta, podrá proporcionar clientes nuevos, dar a conocer la marca entre las personas interesadas y actualizar de forma ágil la información con los clientes, sobre nuevos productos o ventajas para su adquisición.

En las siguientes imágenes, se podrán visualizar algunos de los logros conseguidos: 


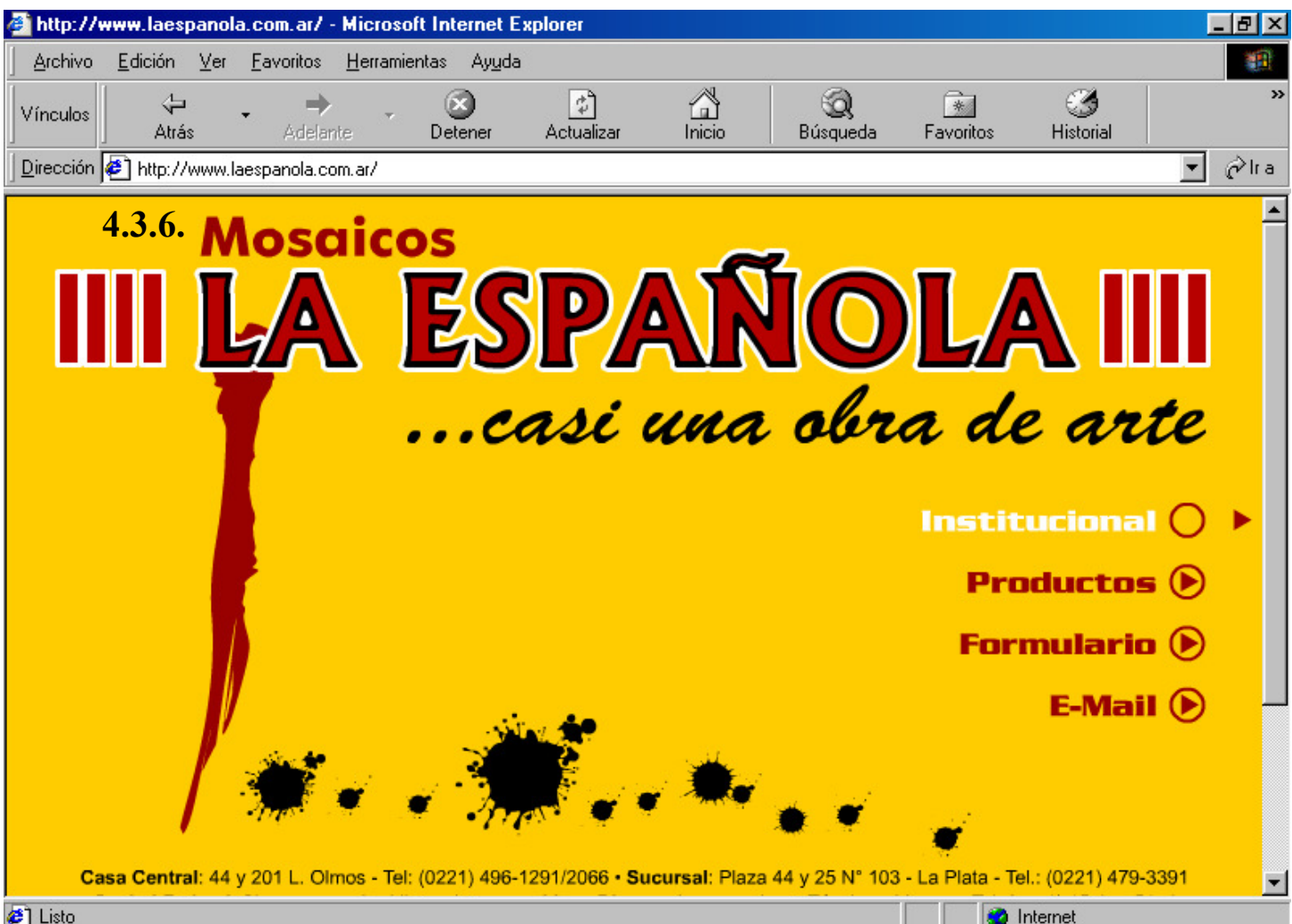

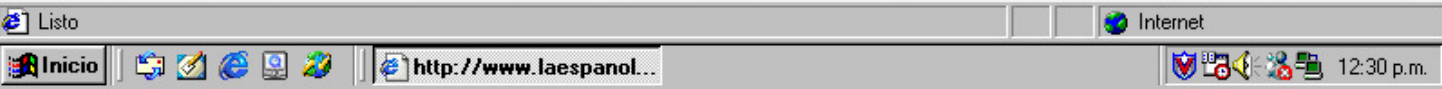

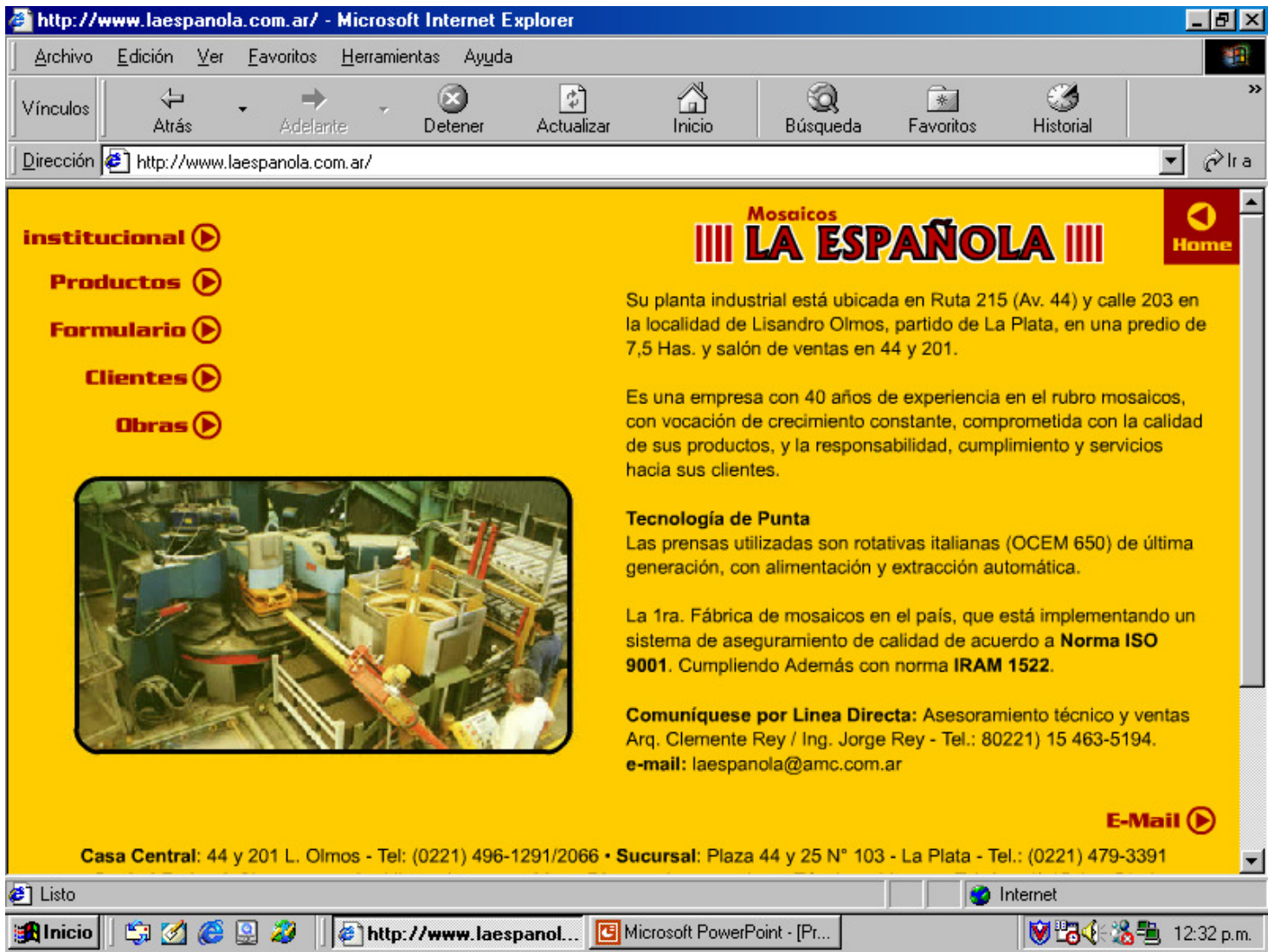




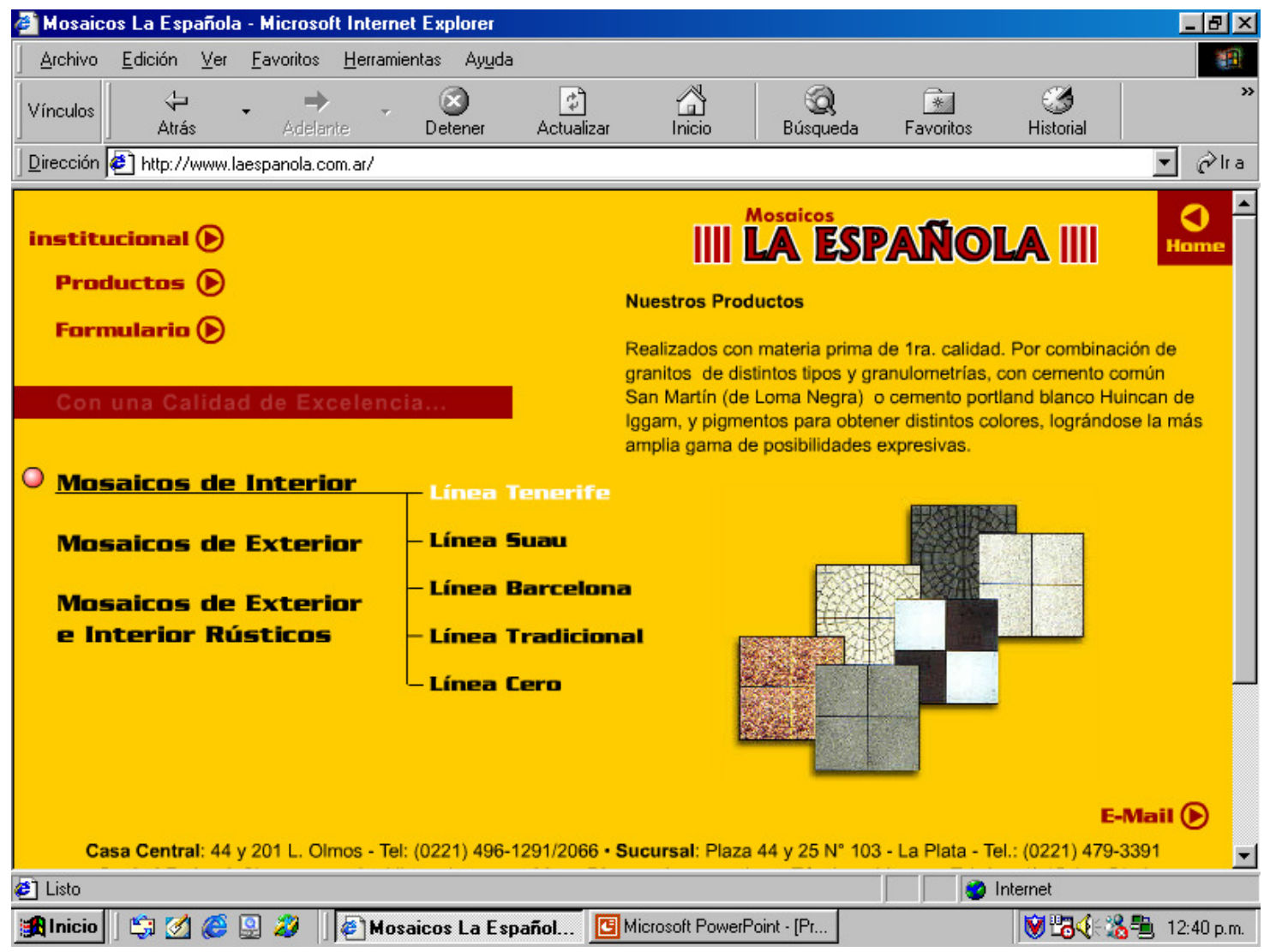

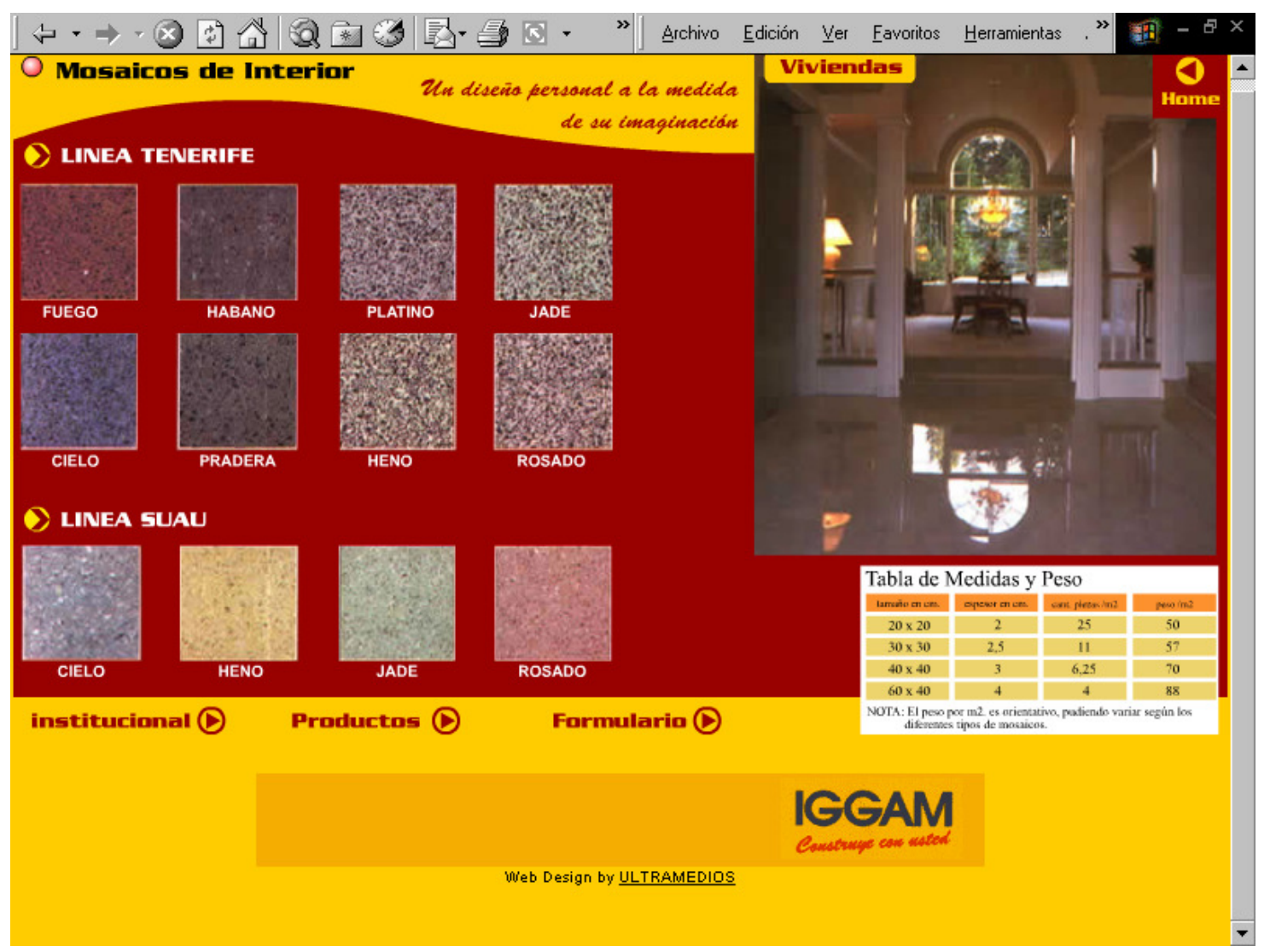



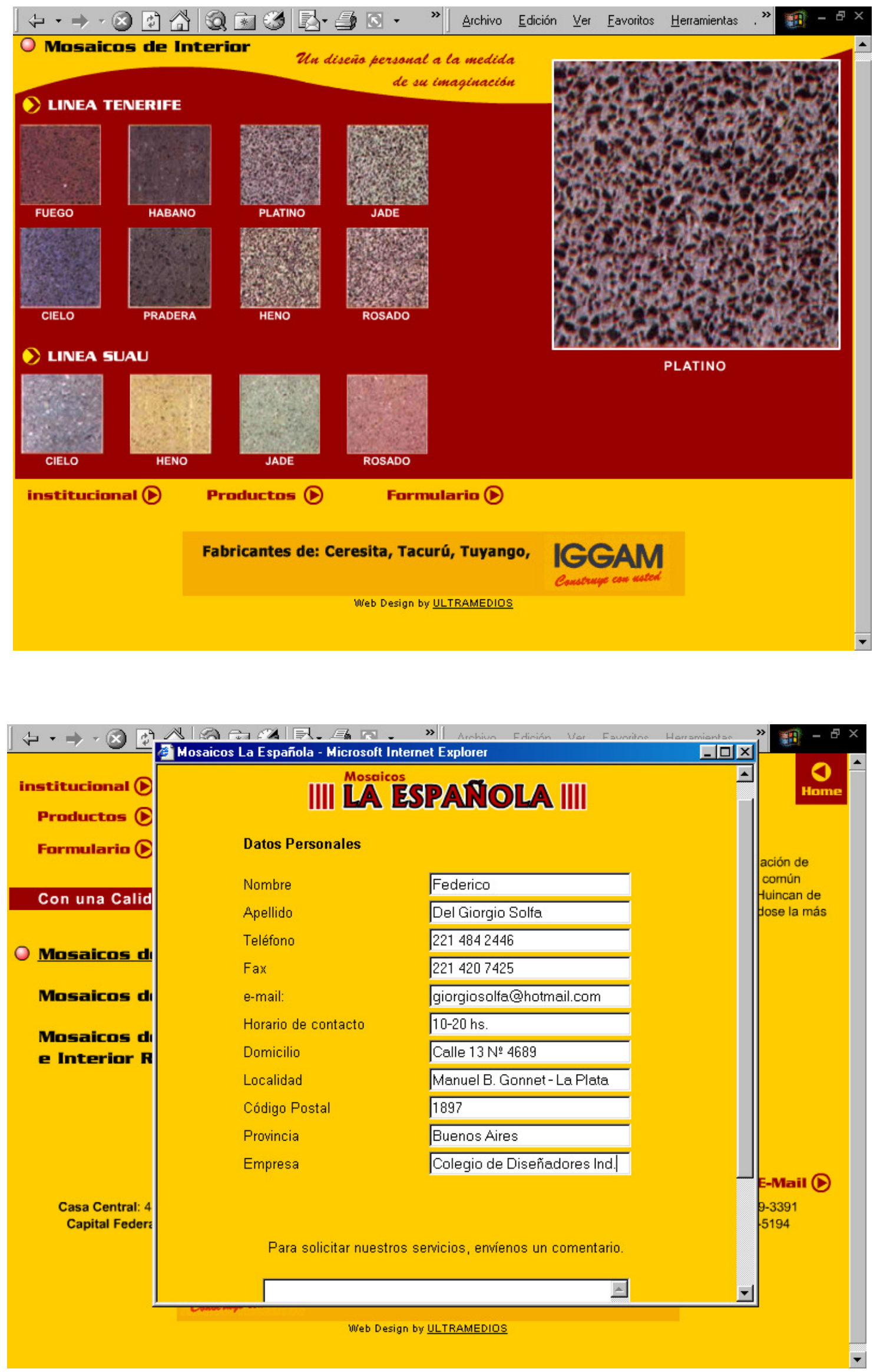


\subsubsection{CD interactivo institucional.}

La reproducción de un CD-ROM muestra una armonía entre imagen y texto. Este equilibrio armónico debe desarrollarse hasta el punto esquemático, sin derivar en imágenes mudas o un lenguaje sin imágenes.

El diseño del CD deberá centrarse en una composición interactiva, que a partir de un banco de datos y mediante textos, figuras, animaciones, video y sonidos, comunique de forma ordenada cómo es la empresa (historia y filosofía) y que características (formales y de uso) poseen los productos que se ofrecen.

Además, a través de éste, el usuario deberá poder simular y experimentar visualmente (con la calidad más aproximada a la realidad) las distintas posibilidades de combinación de mosaicos en una casa tipo.

\subsubsection{Video para publicidad institucional.}

Habiendo relevado los requerimientos de imagen y discurso de empresa; y teniendo identificados los distintos segmentos meta, se desarrollaron los textos institucionales y el guión para el video institucional.

A continuación, se detallan la estructura del guión y el esquema de presentación para la secuencia de imágenes del Video Maestro para Publicidad Institucional de Mosaicos La Española:

\begin{tabular}{|l|l|}
\hline \multicolumn{1}{|c|}{ TEXTO } & \multicolumn{1}{|c|}{ IMAGEN } \\
\hline $\begin{array}{l}\text { Corría el año 1954 cuando a la cabeza de } \\
\text { su familia procedente de Barcelona llega a } \\
\text { la Argentina Don Francisco Rey Tormo. }\end{array}$ & $\begin{array}{l}\text { Fotos antiguas de inmigrantes. } \\
\text { Fotos de los propietarios. }\end{array}$ \\
$\begin{array}{l}\text { Junto con su hijo Luis Rey Vernis montan } \\
\text { una pequeña empresa totalmente artesanal } \\
\text { de fabricación de mosaicos. }\end{array}$ & $\begin{array}{l}\text { Fotos de la primera empresa. } \\
\text { Video de maquina antigua de Fabricación. }\end{array}$ \\
\hline
\end{tabular}


A estos pioneros se les une en poco tiempo Teresa, esposa de Luis.

Fueron años difíciles, llenos de esfuerzo y sin sabores, pero también eran años de crecimiento, y esos esfuerzos dieron sus frutos

Y estos frutos fueron, ser en la década del setenta una de las primeras empresas en poseer maquinas automáticas para fabricar mosaicos con tecnología nacional que permitía con muy pocos operarios cubrir la demanda de una ciudad en constante crecimiento como era La Plata.

En el año 1987 con sus flamantes títulos de arquitecto e ingeniero bajo el brazo toman la conducción de la empresa Clemente y Jorge, nietos de aquel pionero fundador iniciando una nueva etapa.

Se construye una planta industrial modelo sobre un predio de mas de siete hectáreas, trabajando siempre con una filosofía de puertas abiertas a las nuevas tecnologías.

Y se compra la primera maquina de tecnología europea totalmente automática, anexándole equipos de dosificación y extracción automática desarrollados por el personal altamente calificado de la empresa.

Hoy partiendo de materias primas tan nobles como la arena, el cemento y piedras de todo el mundo, controladas por un riguroso sistema de calidad, confluyen en la fabricación a través de máquinas que incorporan lo ultimo en tecnología del mundo; de mosaicos que cumplen sobradamente las expectativas del consumidor más exigente.

Pero la tecnología no es todo, importa mas el componente principal en la fabricación de cualquier producto,
Fotos de la empresa mejorada.

Video de producción mejorada.

Video de vieja maquina productora.

Video de frente de nueva planta.

Video de interior de la fábrica actual.

Video de materias primas.

Video de persona controlando materiales.

Video de maquina produciendo.

Video del panel de control de la máquina.

Video de directivos en el interior de la fábrica dando órdenes, o dirigiendo.

Video de gente en la calle.

Video de puntos de venta.

Video de gente comprando.

Video de gente opinando con los vendedores sobre bondades de productos.

Video de diseñadores trabajando en nuevos diseños.

Imágenes de computadoras. Planos y fotos de mosaicos. 


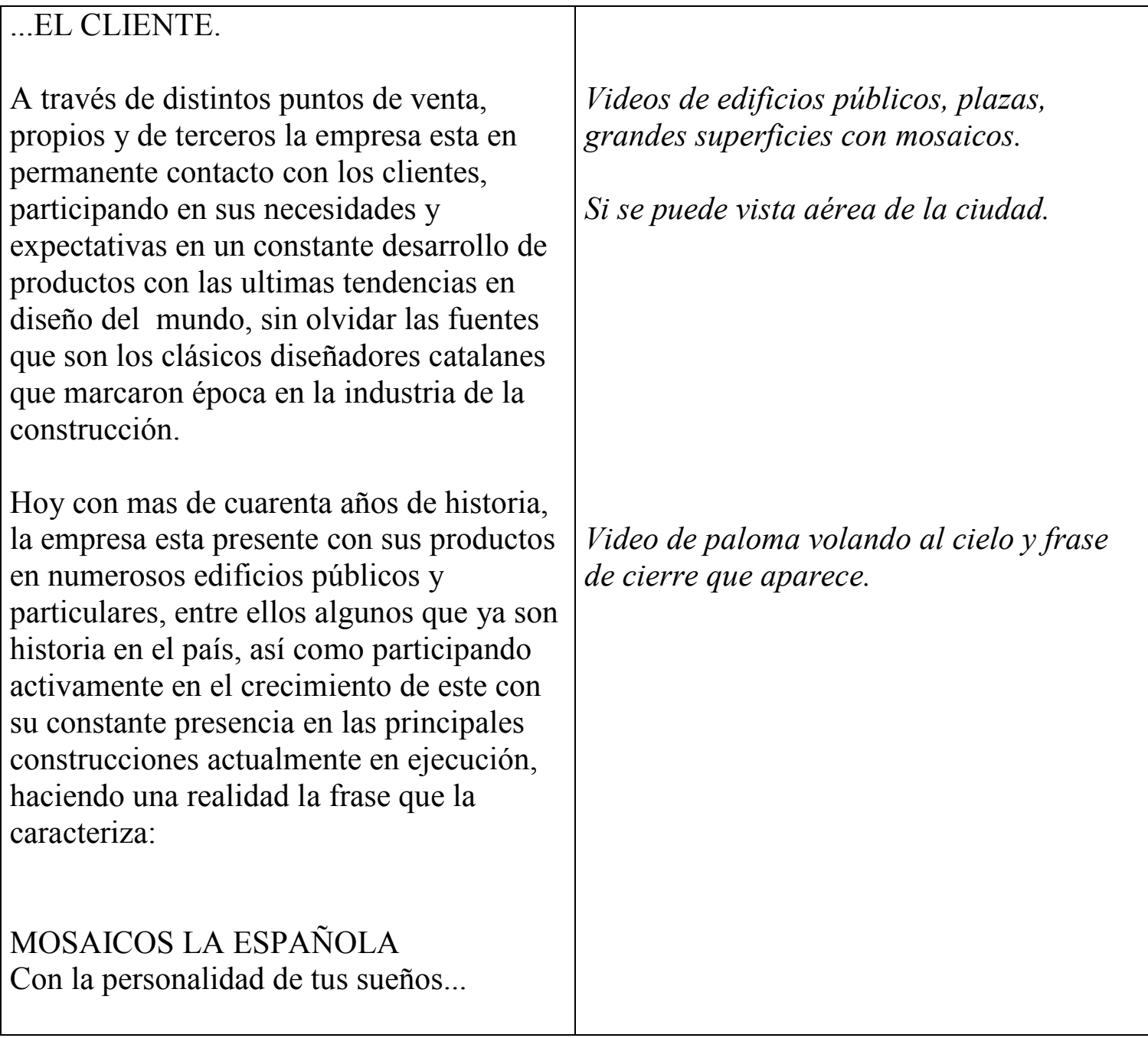

\subsection{Diseño de Producto.}

Los productos cambian con los avances tecnológicos y con los cambios en la moda o en la condición económica general. Por ello el diseño de los mosaicos, tendrá que ser coherente con cada situación.

Una vez tomada la decisión sobre cuál va a ser la gama de productos, no hay que mantenerla igual por demasiado tiempo, sino que debe ser evaluada con frecuencia. Ésta, se podrá realizar a través del análisis de los inventarios y registros de ventas. 


\subsubsection{Nuevos diseños de mosaicos.}

En esta fase, no se siguió a la tendencia del sector por considerarse demasiado estática. Para no colaborar con este estancamiento, se desarrollaron nuevos mosaicos siguiendo las consignas de innovación tecnológica y formal.

Como parte de nuestro trabajo de desarrollo de producto ${ }^{19}$, se han diseñado gran cantidad de nuevos mosaicos, adecuándolos a las necesidades detectadas e incorporando:

- Un poderoso concepto estético.

- Nuevos materiales y elementos decorativos que amplíen el segmento objetivo hacia nuevas tendencias de decoración como rurales, country, atrevidas, etc.

- Generación de nuevas líneas de productos y herramientas comunicacionales asociadas que denoten el crecimiento de la empresa y la preocupación constante en la nueva oferta de productos, cada vez más direccionados hacia las necesidades propias de cada cliente.

En función de estos parámetros, se han desarrollado los nuevos diseños de productos y de líneas que se exponen a continuación.

\footnotetext{
${ }^{19}$ En la relación diseñador-productor, es importante que emerja la actitud intelectual que considera cada proyecto-producto como un componente modesto de un escenario más amplio; "una tercera vía en la que la cultura siga desempeñando aquel rol crítico-constructivo que supo desarrollar la humanidad en sus mejores momentos". (MANZINI, EZIO, 1990).
} 


\section{Diseños con insertos mosaicos (ubicación RND):}
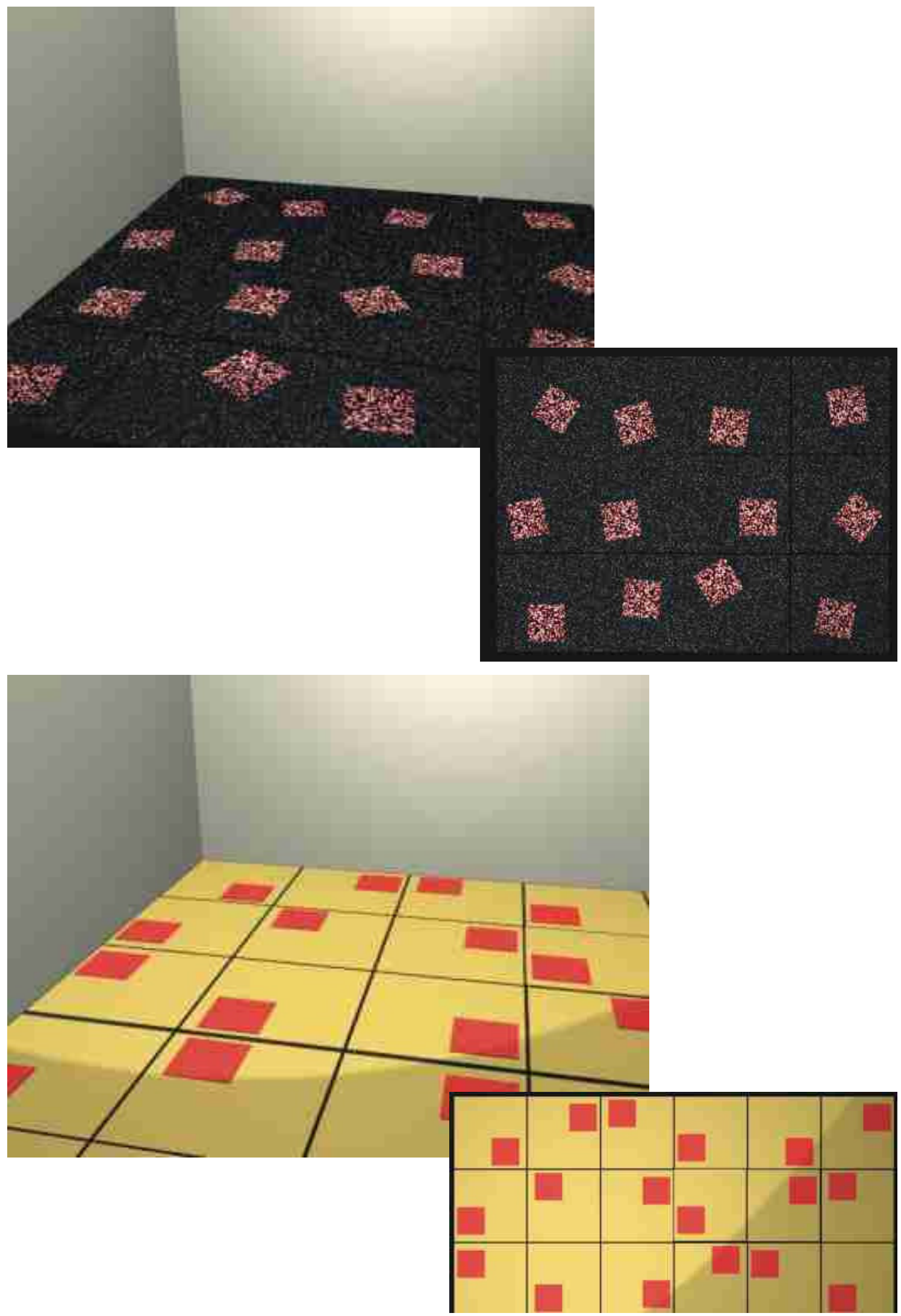

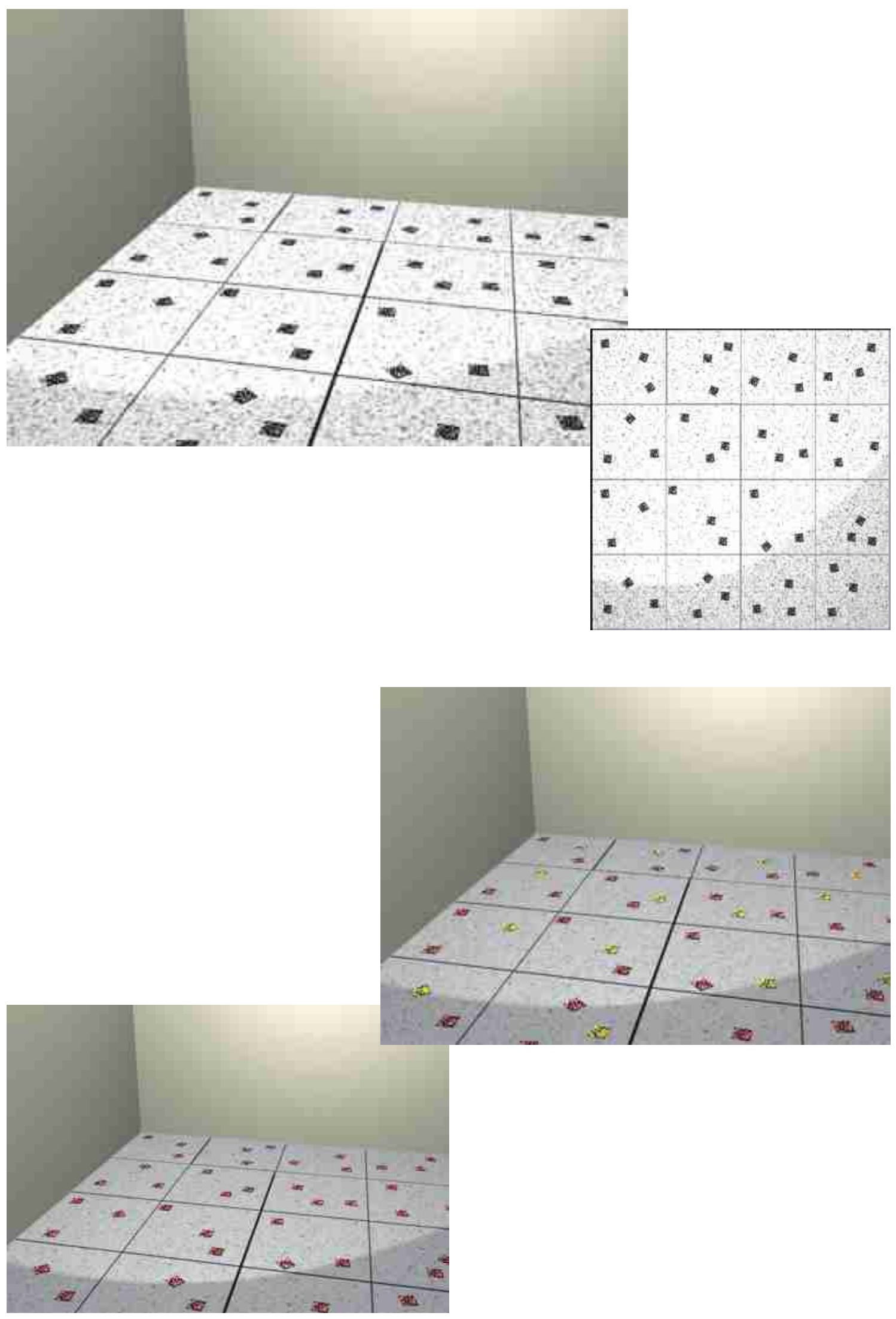

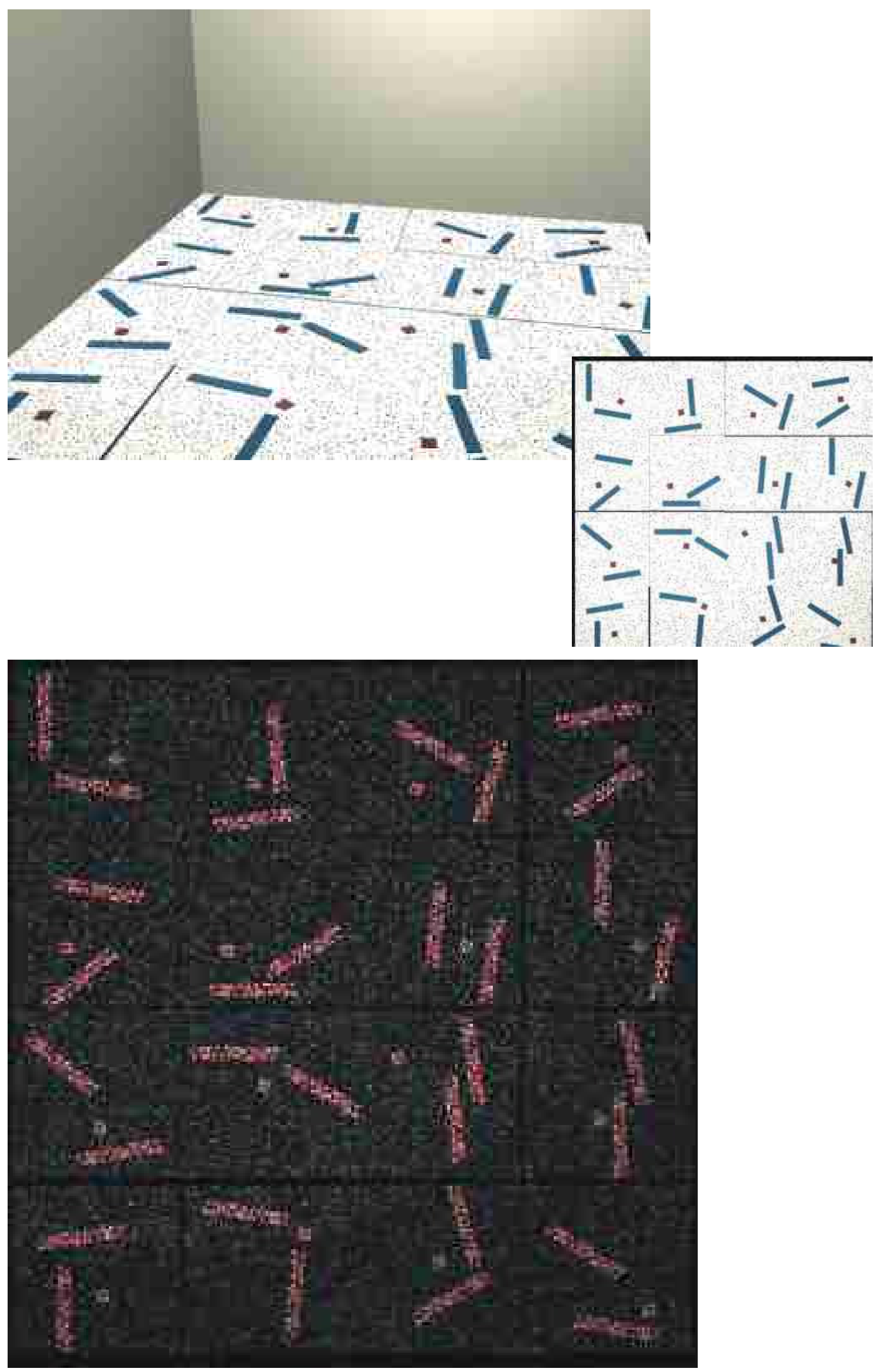
Diseños con insertos mosaicos (ubicación regular):
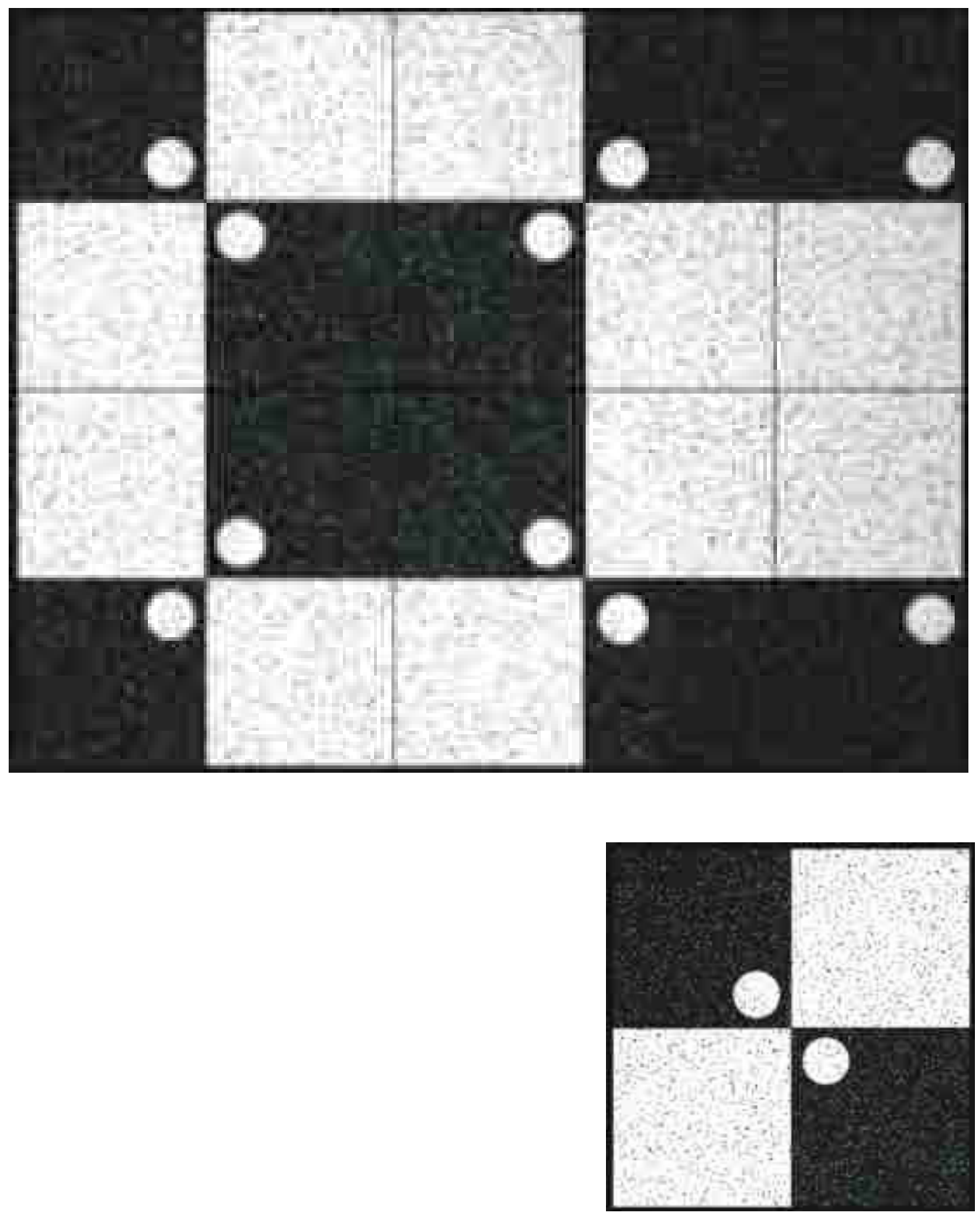

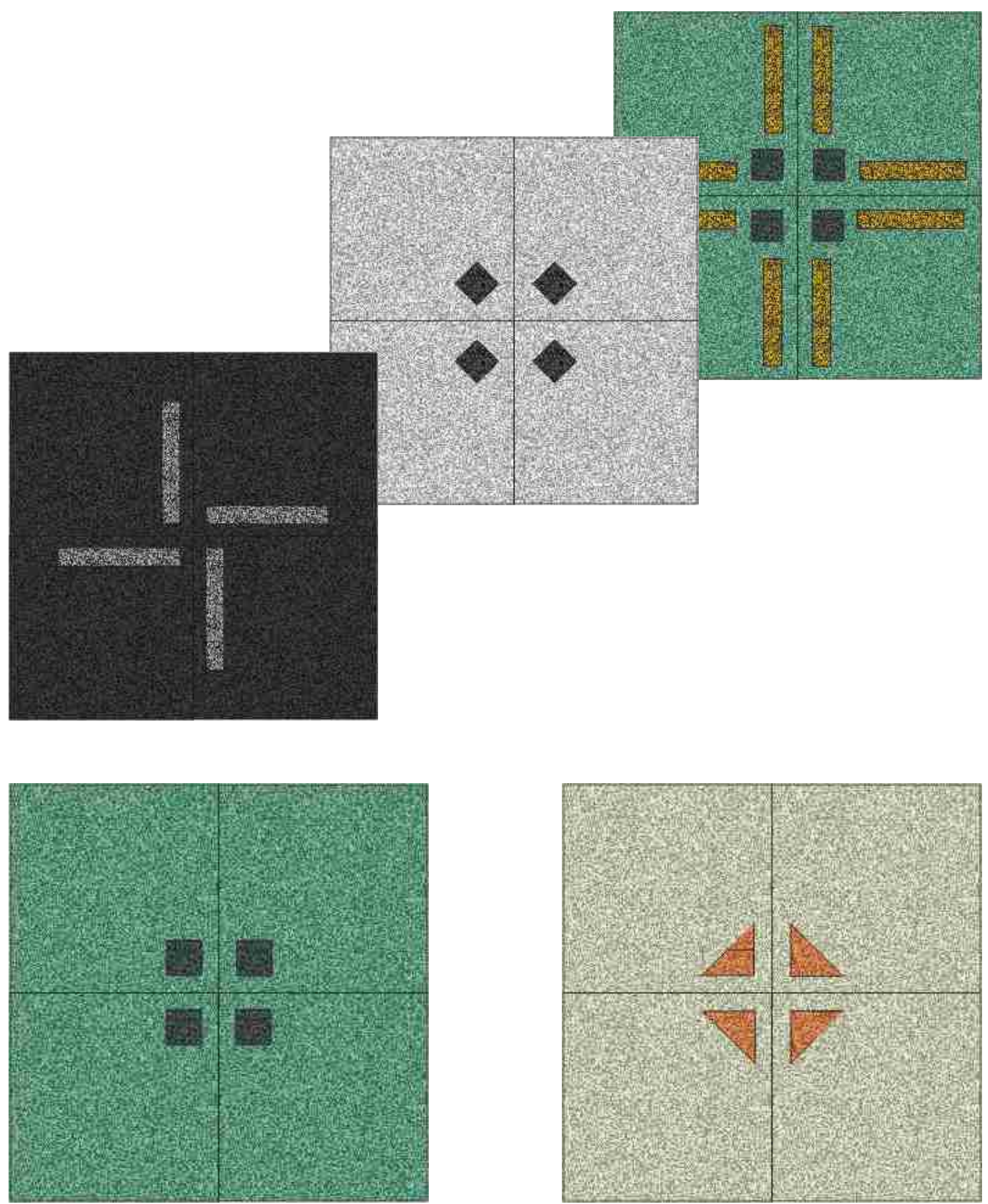
Diseños basados en corte y/o colocación:
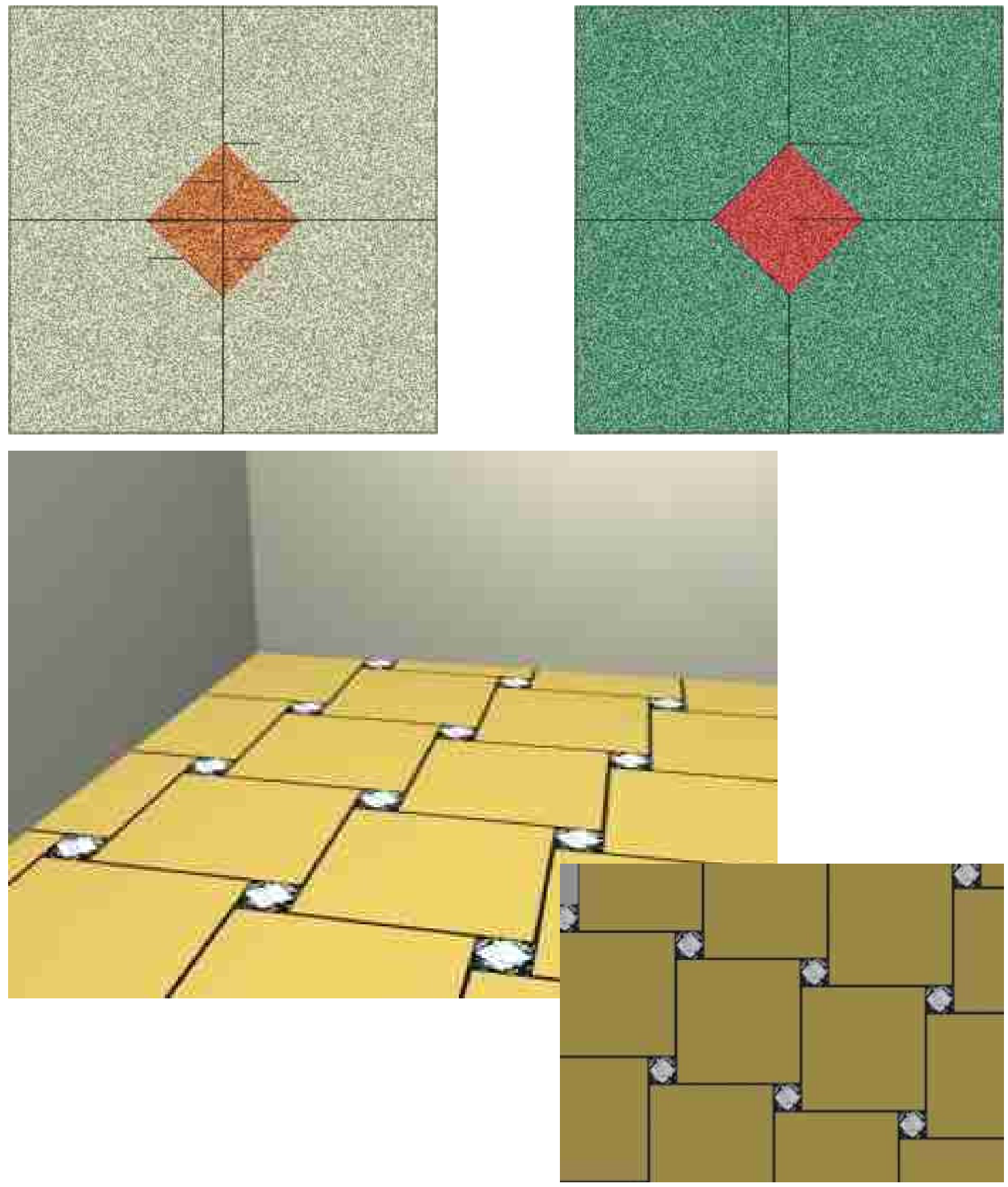

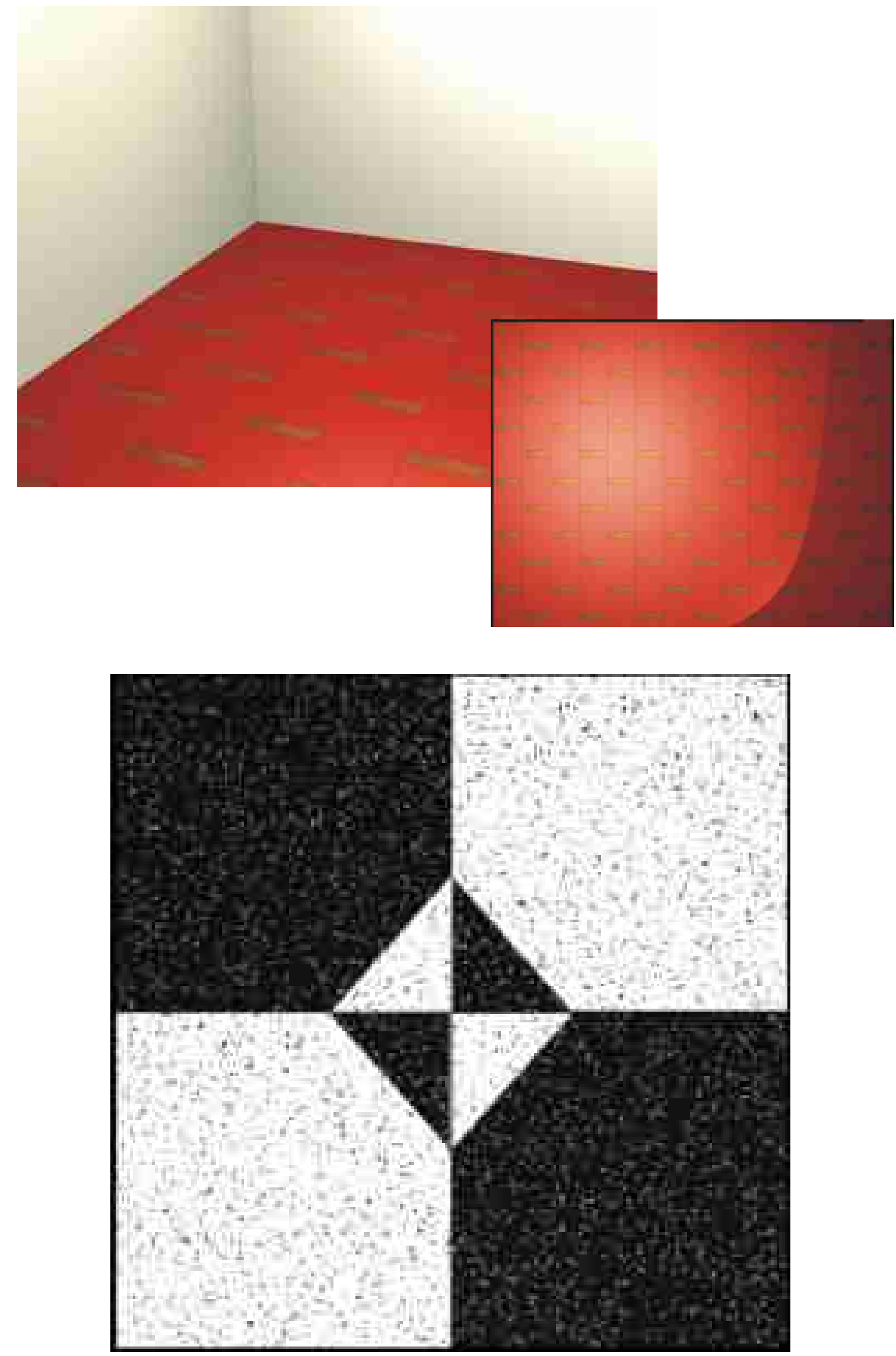


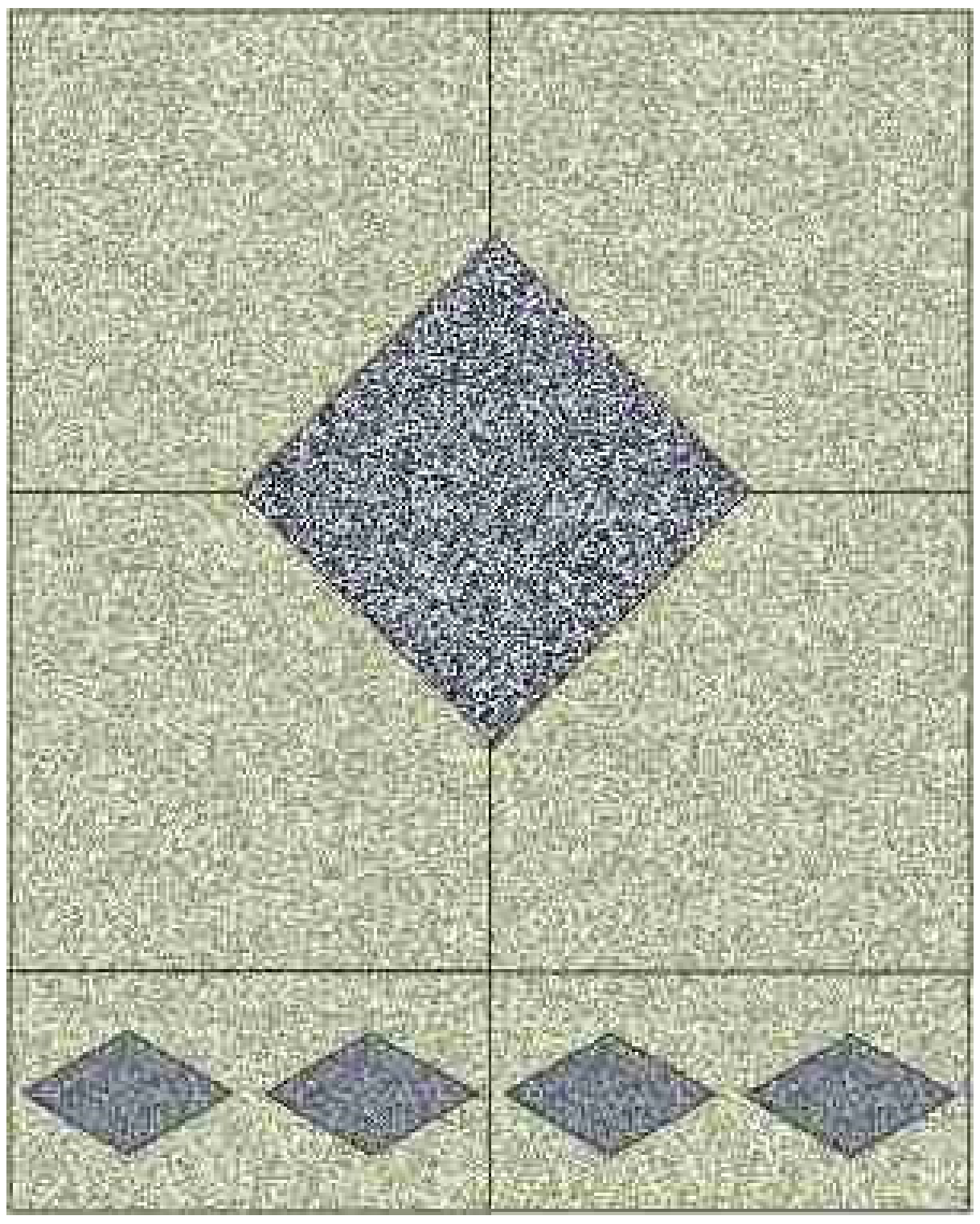




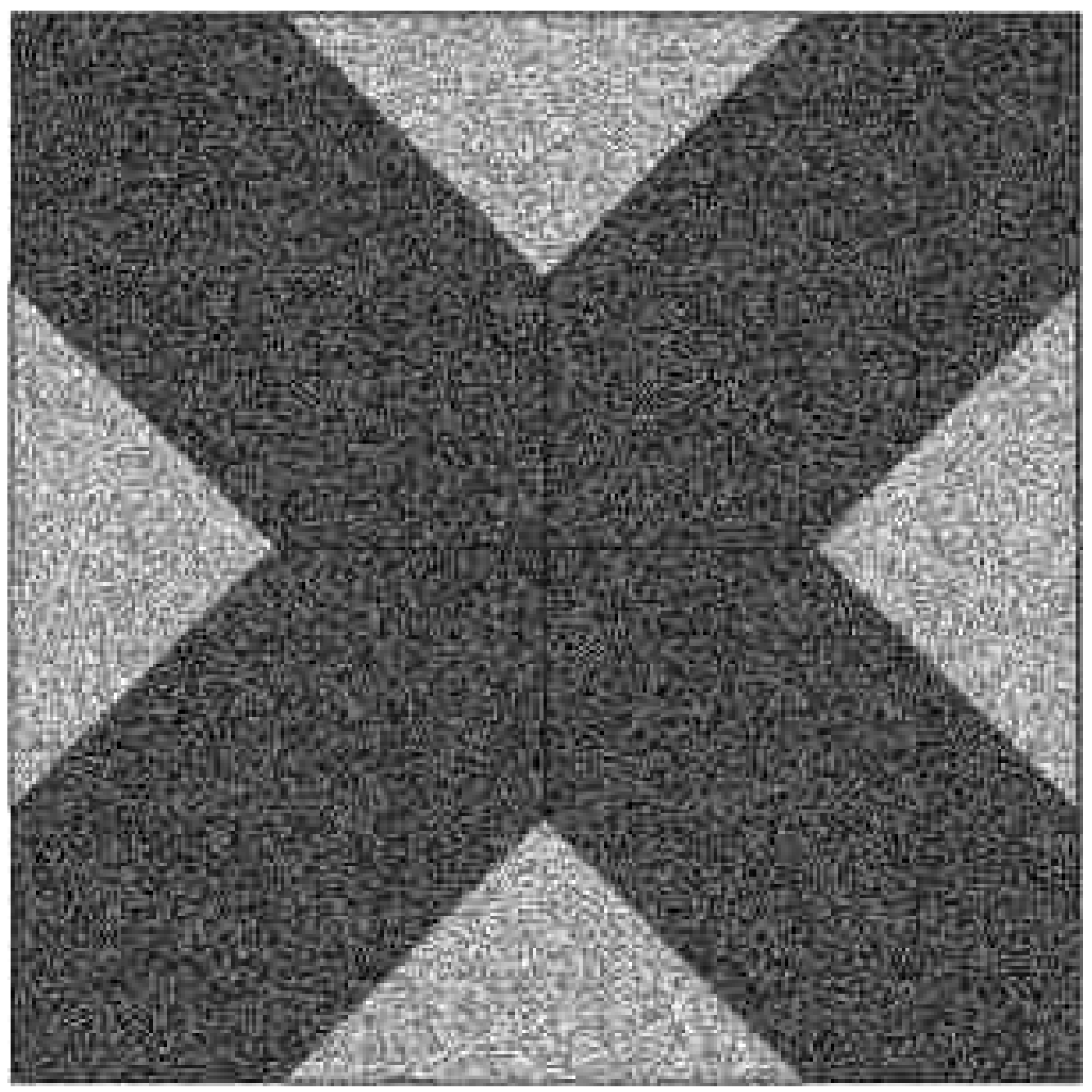




\subsubsection{Diseños exclusivos de mosaicos.}

Dentro del grupo de mosaicos proyectados, se trabajó en el diseño de mosaicos exclusivos. Estos mosaicos poseen una gran diferenciación a los conocidos en el actual mercado, esto se debe a un desarrollo de innovación ${ }^{20}$ tecnológica que permitió alcanzar nuevos resultados formales a través de insertos mosaicos y metálicos.

Los mosaicos generados a partir de insertos mosaicos, marcan una innovación importante en el sector, permitiendo así llegar al público más arriesgado en cuanto a diseños o modas.

Por otro lado, los insertos metálicos fueron utilizados de alguna manera en el pasado, pero ya hace más de medio siglo que no se producen.

La producción de estos nuevos modelos de mosaicos es altamente flexible, permitiendo la personalización de formas y colores tanto para los insertos mosaicos como para los insertos en acero inoxidable.

A continuación, se pueden observar los distintos diseños y alternativas ${ }^{21}$ de estos mosaicos.

\footnotetext{
${ }^{20}$ La innovación podría definirse como una actitud que permite ver más allá del presente y crear una visión de futuro para la empresa. Dicho de otra manera, se trata de anticiparse a los competidores con un producto o servicio. De esta forma se obtiene una posición única. Innovar es un proceso, que parte de la gestación de una idea hasta la llegada de un producto a manos de un consumidor.

Según THOMAS D. KUCZMARSKI: "La innovación no es simplemente otra manera de desarrollar productos y servicios o de difundir vida en los ya existentes. Es mucho más amplia. La innovación es la mejor y única manera de sortear la competencia, adelantarse al conjunto de la industria y lo que es más importante, crear productos nuevos para el mercado que refuercen los márgenes de ganancia y promuevan los sistemas de ingresos. Es decir, puede resultar el arma competitiva, más poderosa de una compañía". (Pág. 90, "En Busca de una Nueva Mentalidad". Sección File de la Revista Gestión Vol. 2 № 4, JulioAgosto de 1997, Buenos Aires Review).

21 "La habilidad de desarrollar y considerar alternativas, es a menudo tan importante como lo es seleccionar la mejor de ellas". (WEISS, W. H. 1987).
} 
Diseños con insertos metálicos (Coladas de Acero Inoxidable AISI 304/316 y Latón):
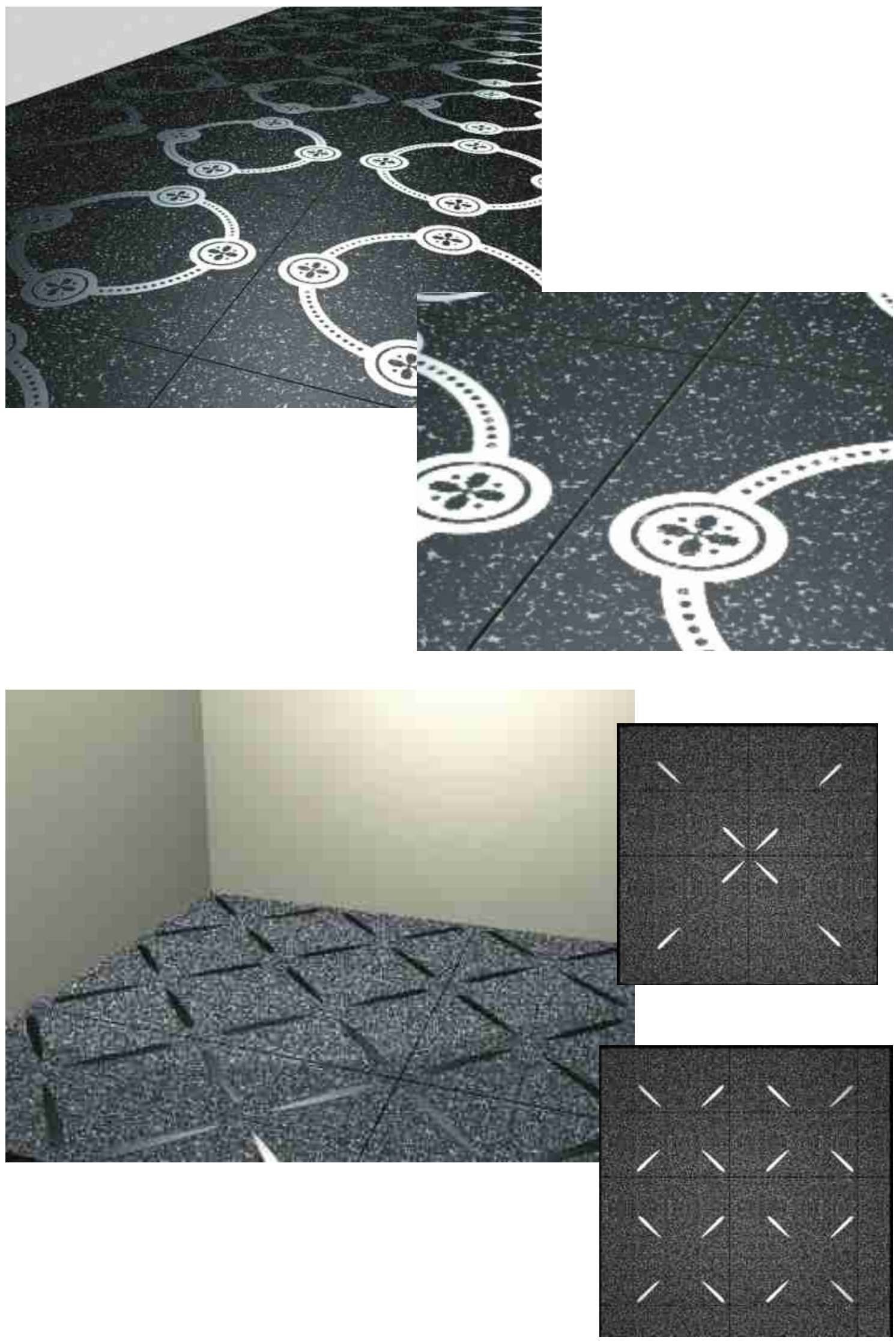

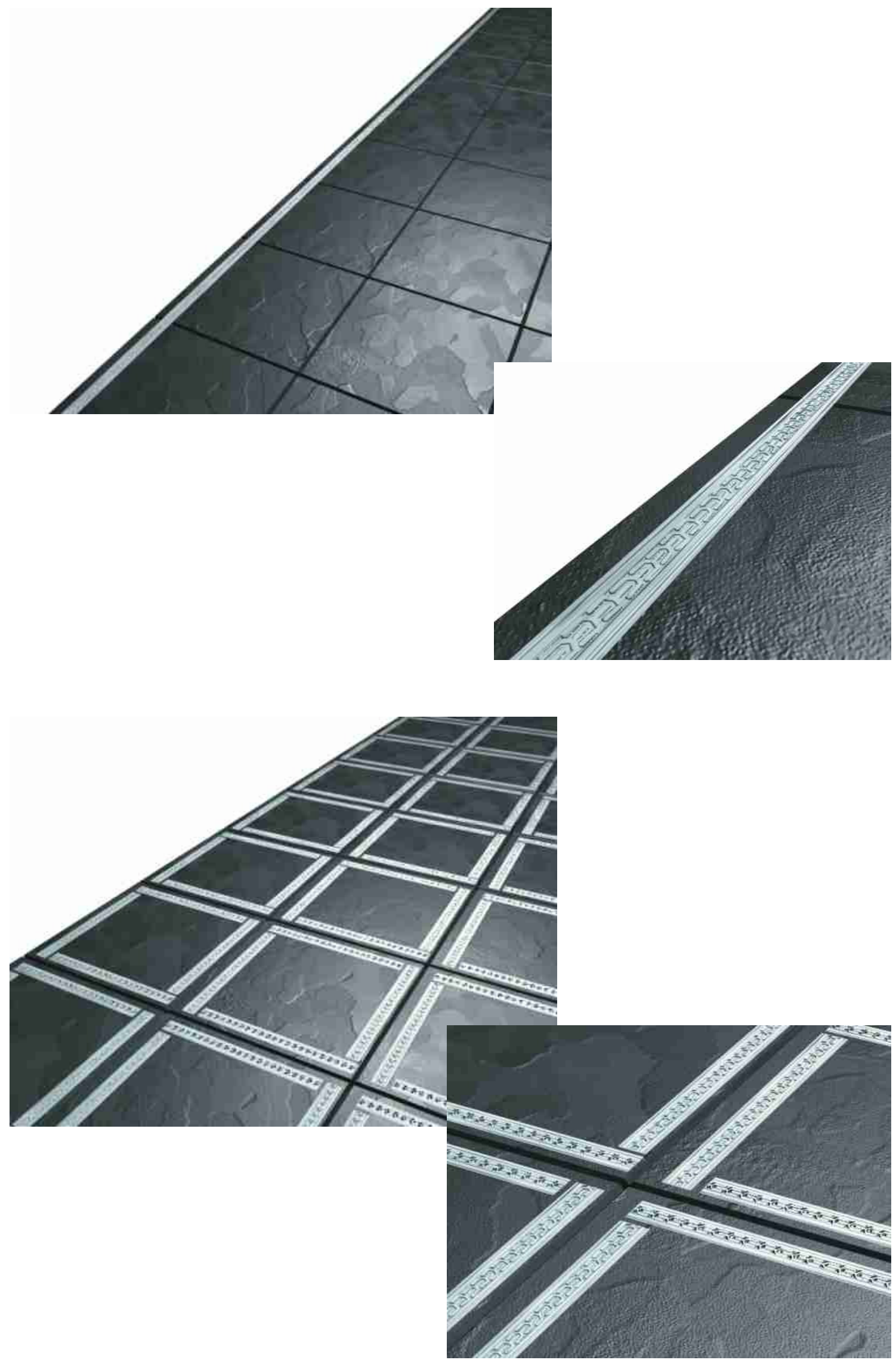

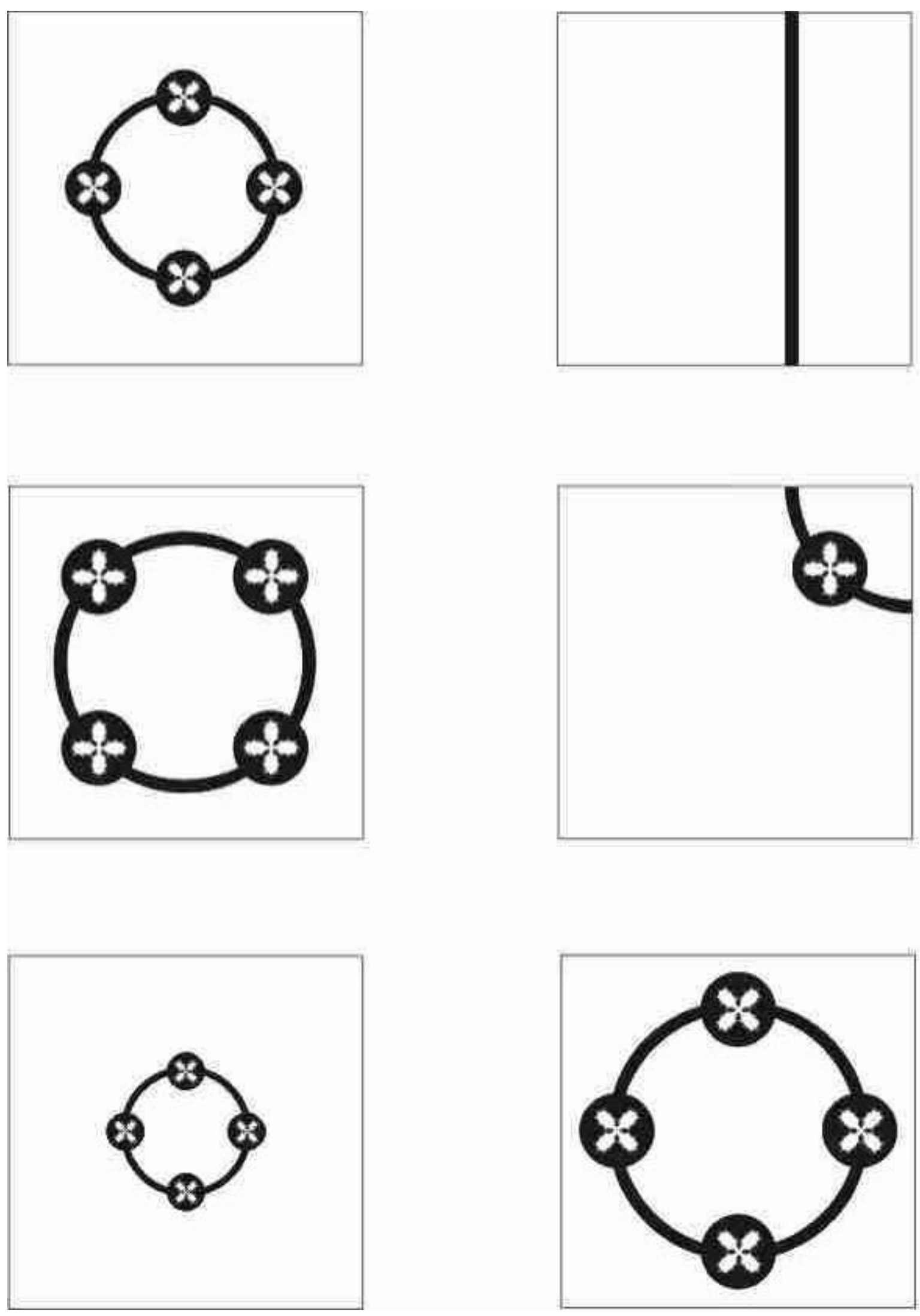

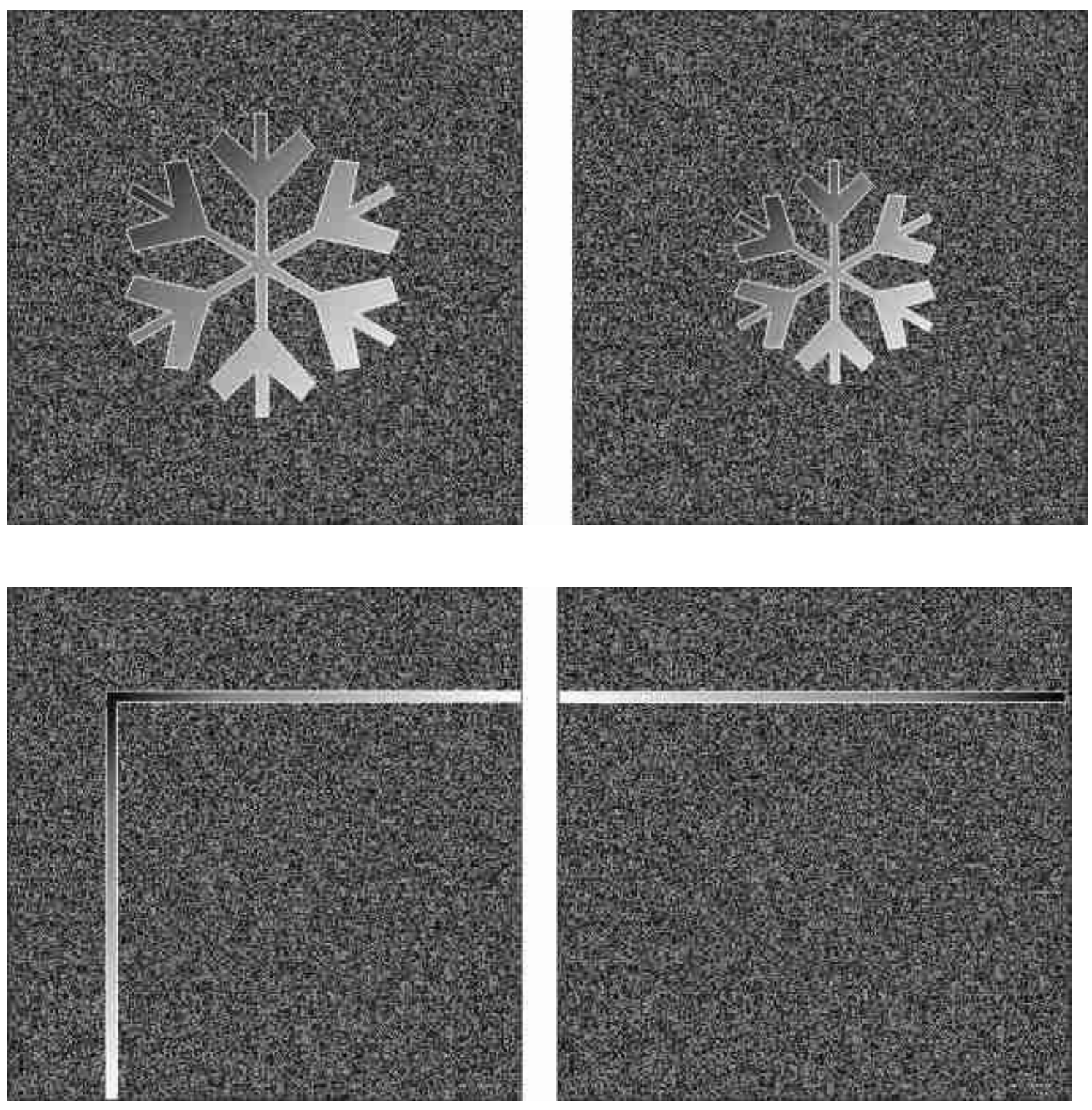

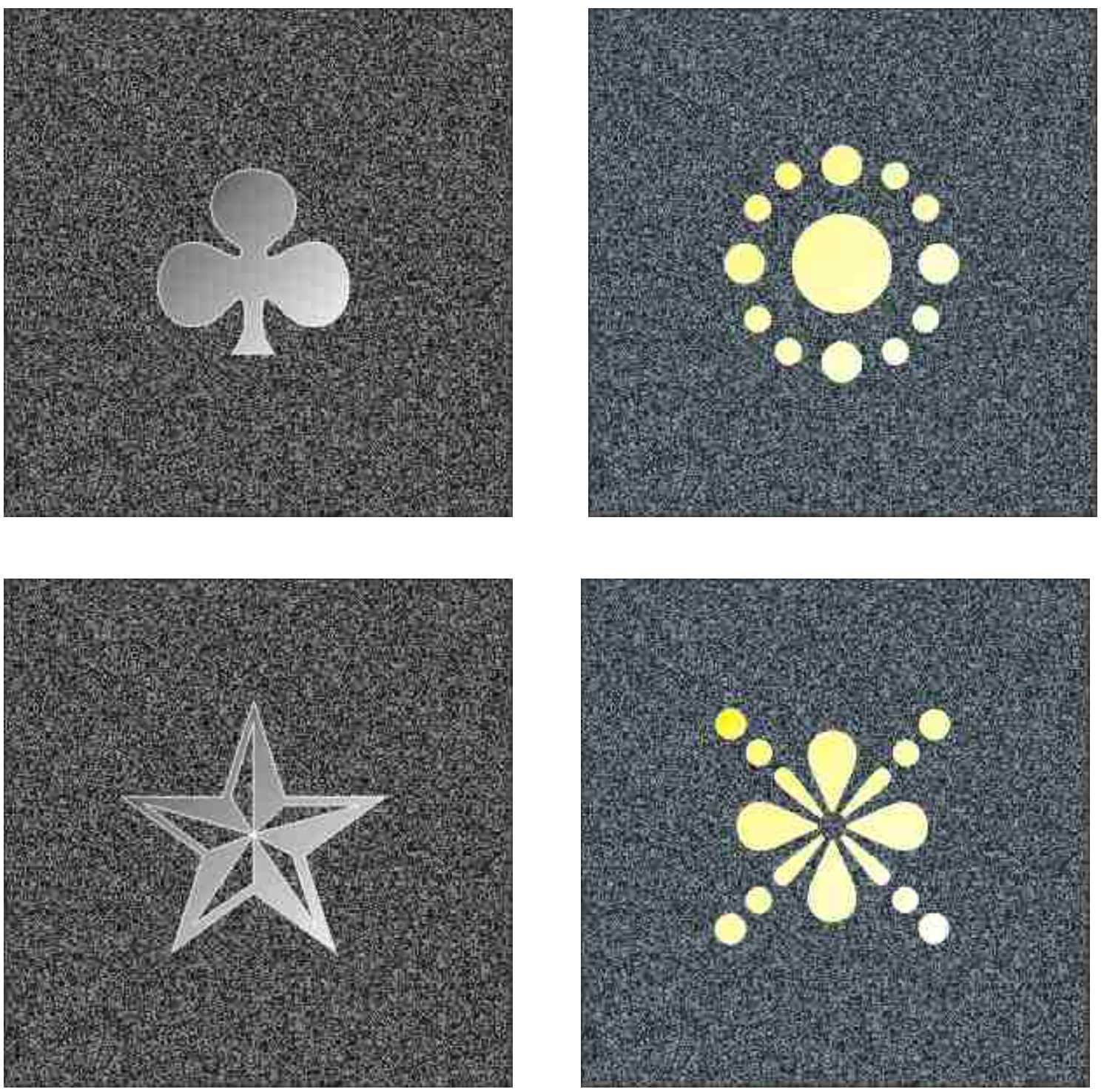

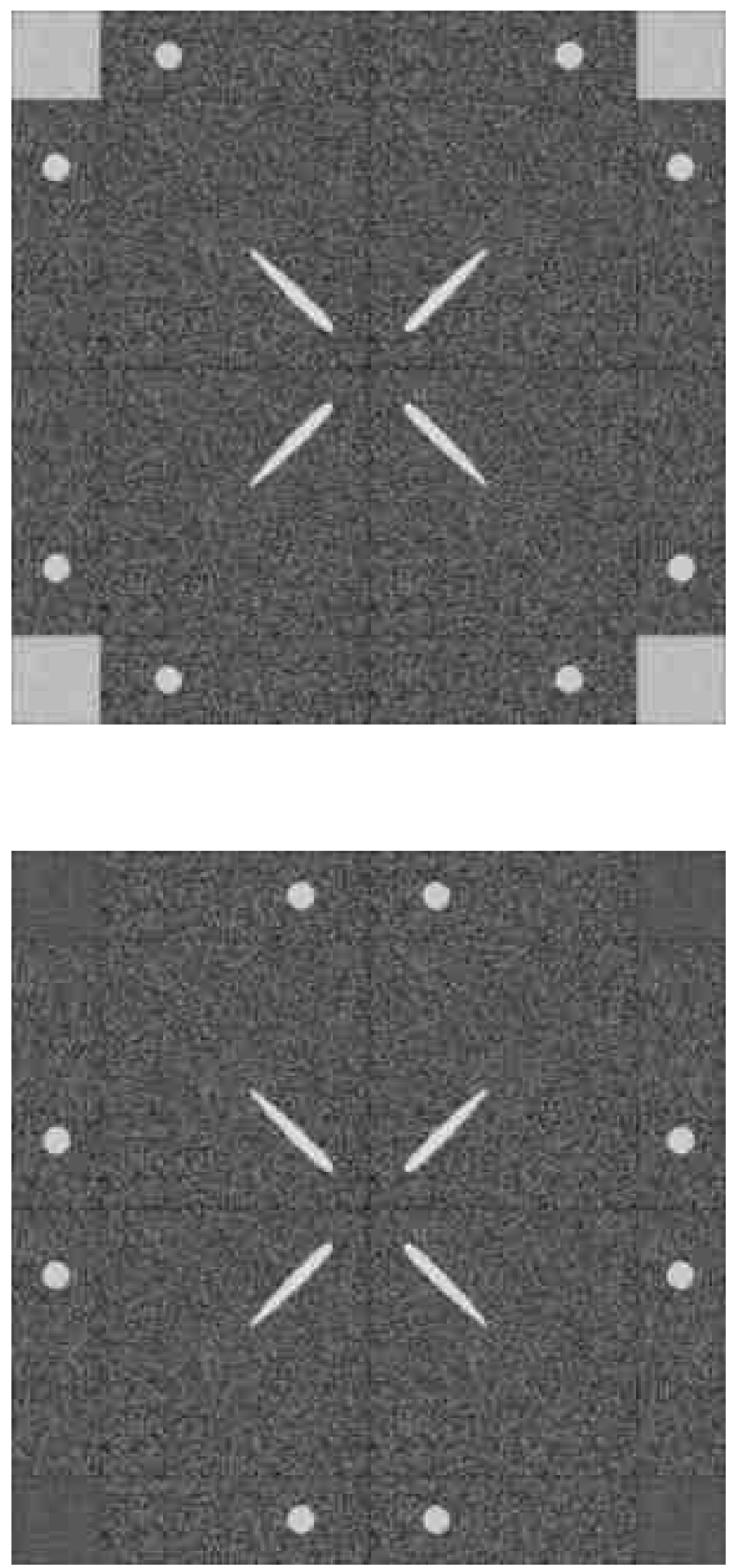

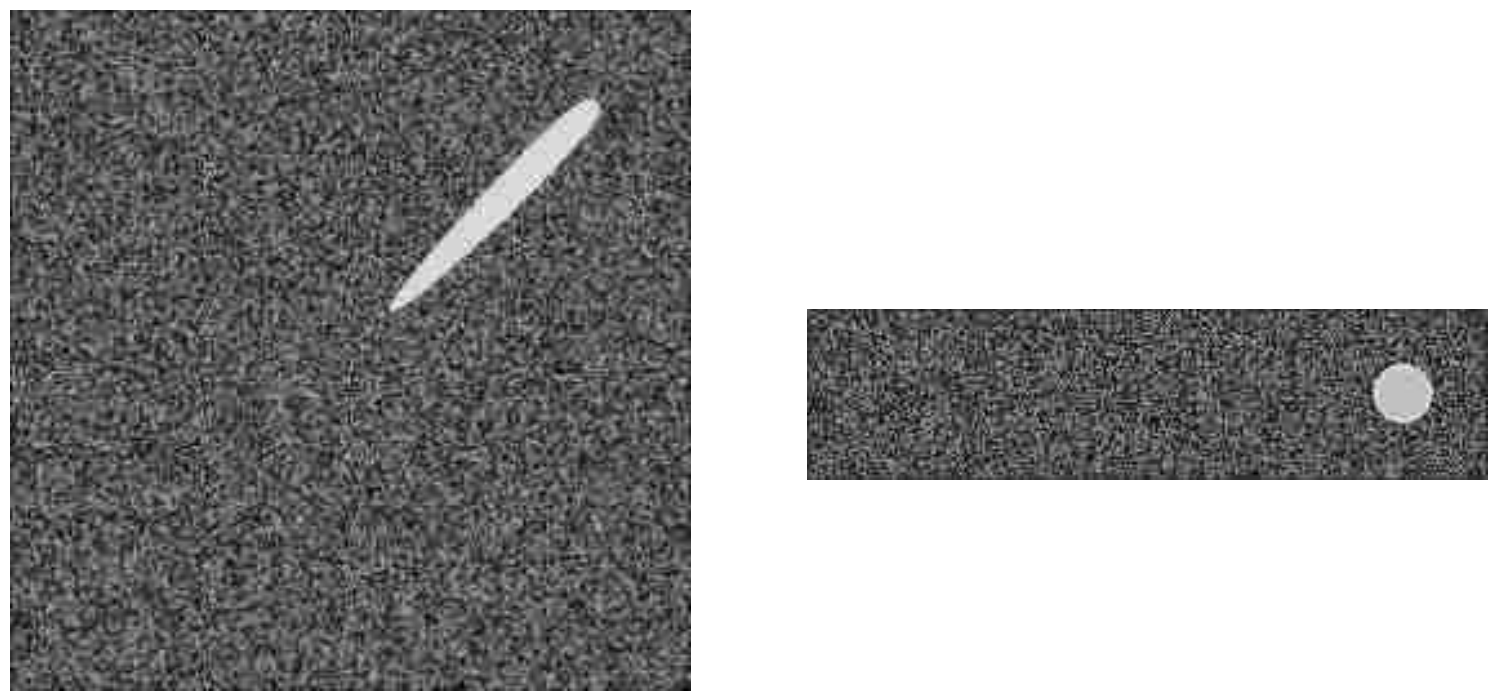
Diseños con insertos compuestos (Acero Inoxidable o Latón con llenado de color):
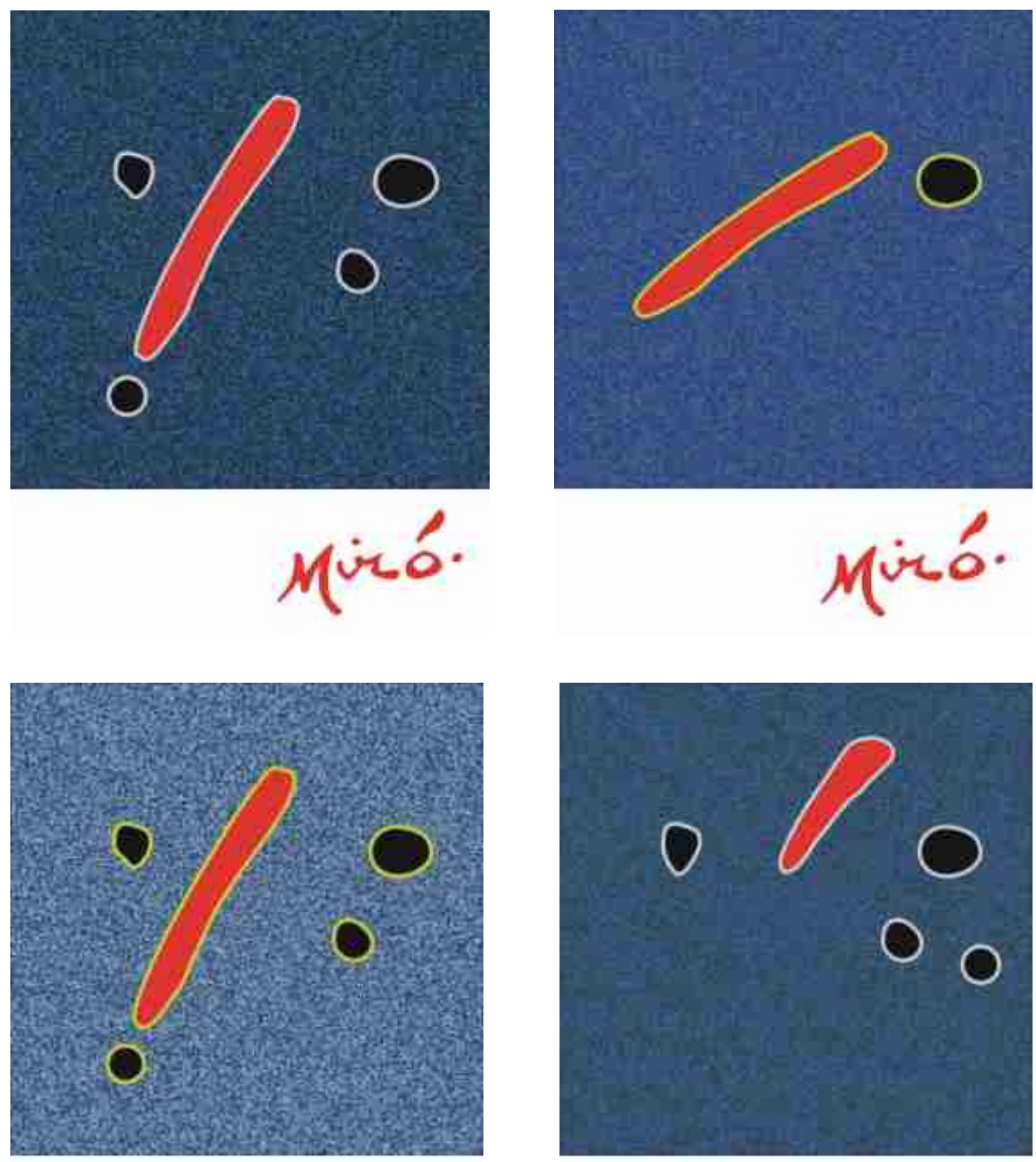

$$
\text { Miró. }
$$

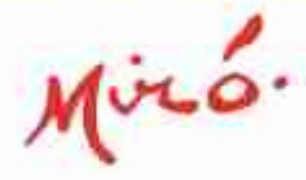



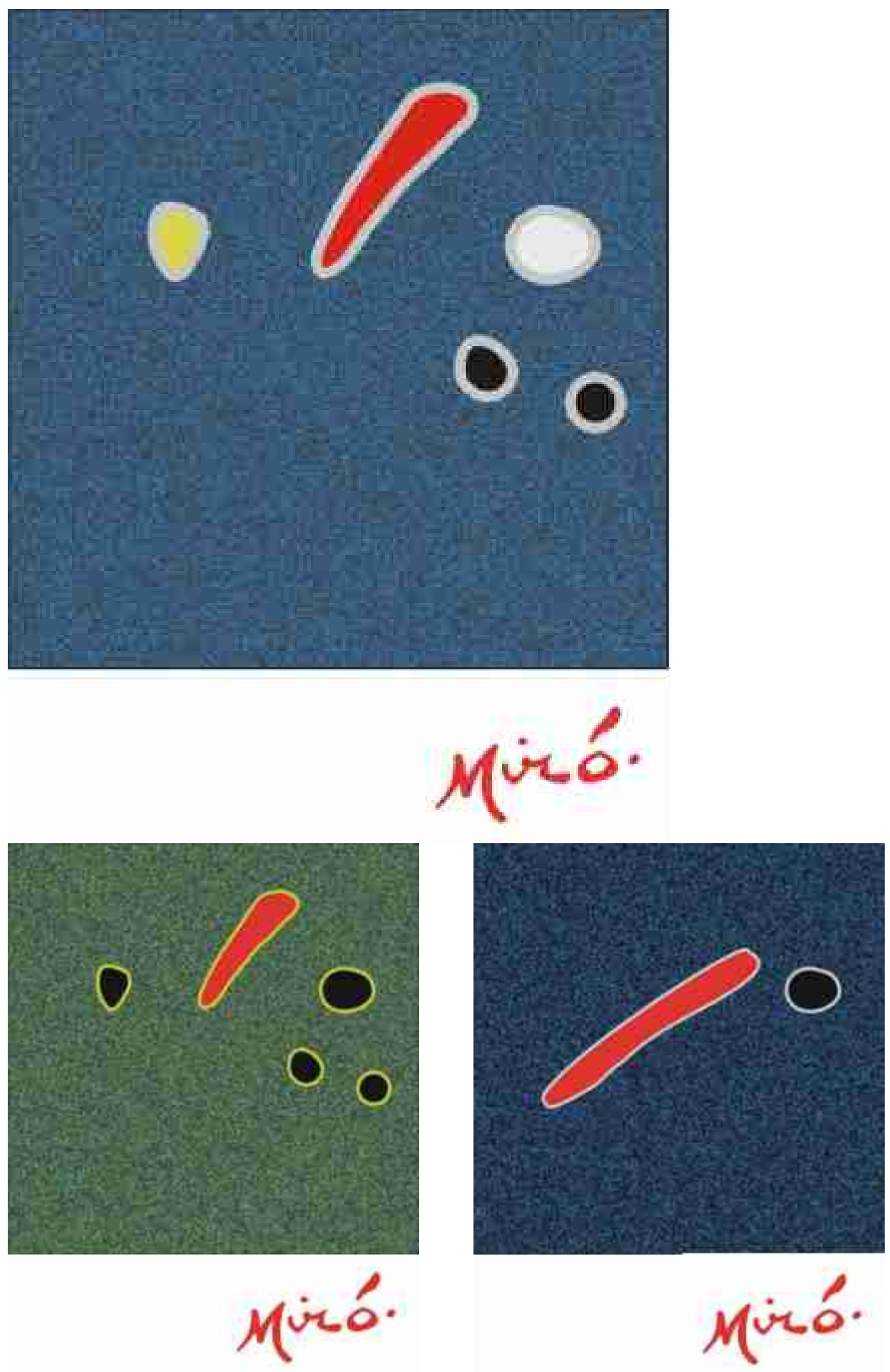

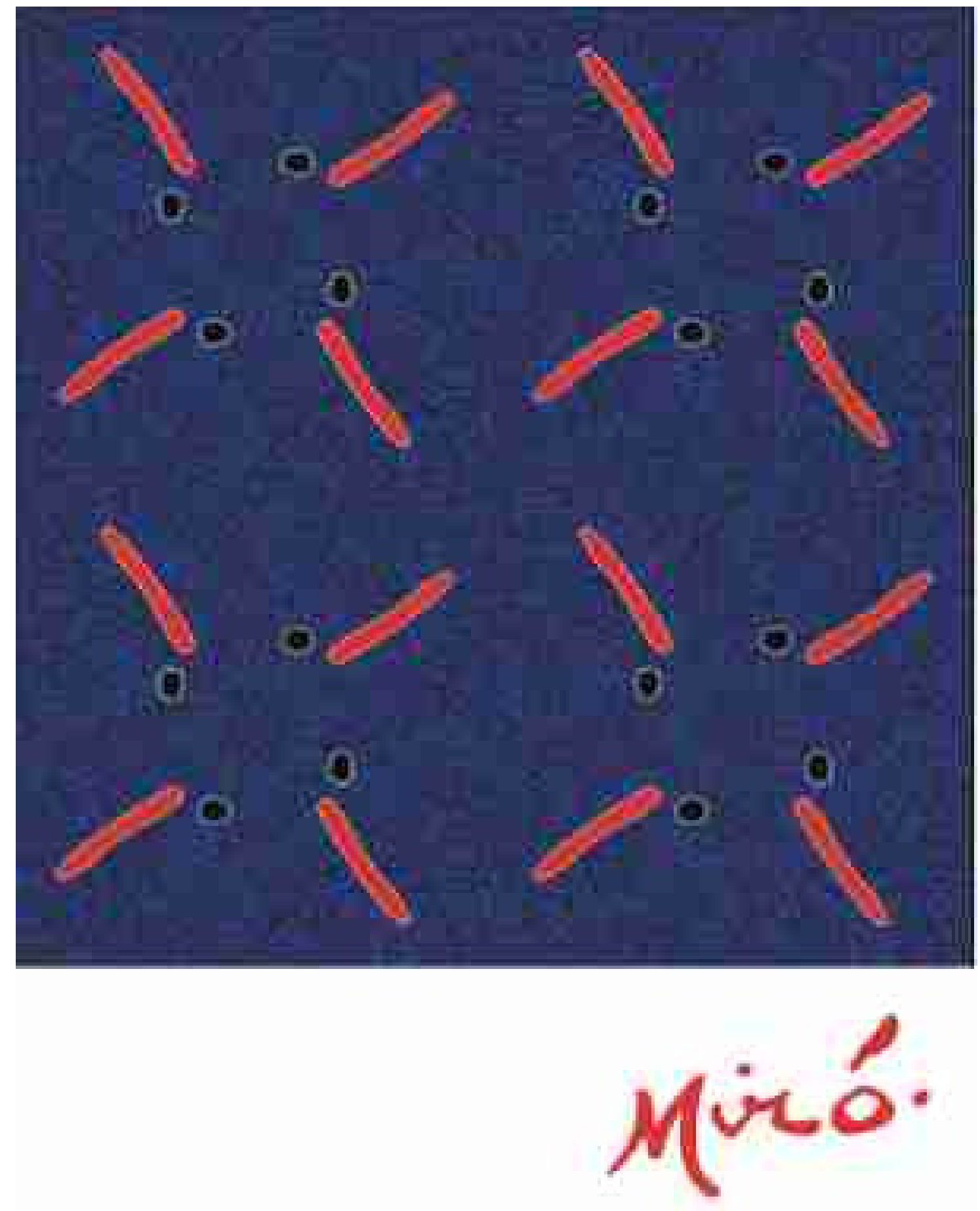

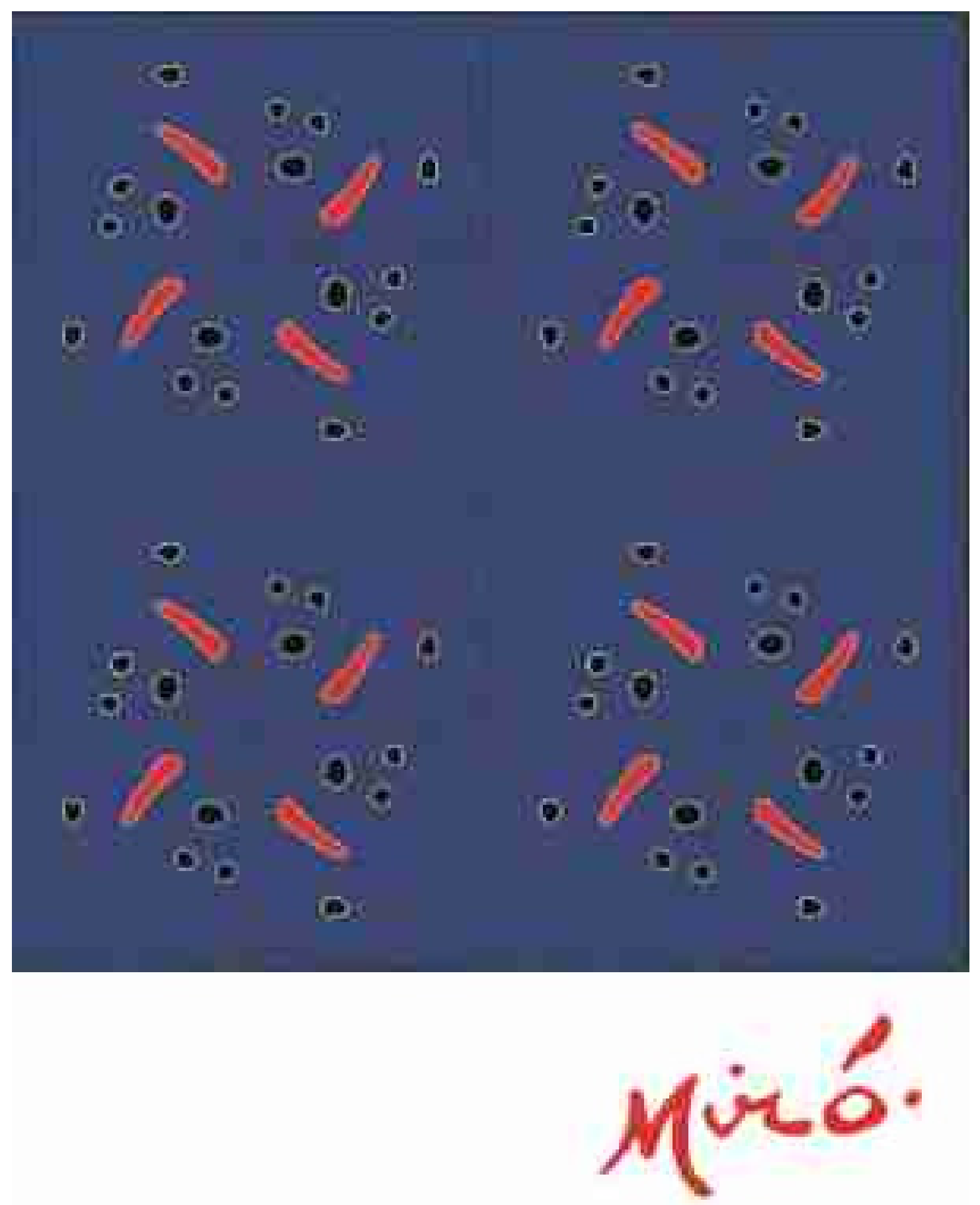


\subsection{Características del personal de contacto y de ventas.}

También era necesario reforzar la presencia de La Española mediante una acción comercial pro-activa, de allí la importancia de contar con un cuerpo de ventas entrenado para detectar potenciales clientes, realizando una acción comercial que lleve la empresa al cliente, acción que hoy nadie está realizando en este sector.

Para ello se realizó en primer lugar una definición de las necesidades y luego una búsqueda de los perfiles necesitados. A través de un aviso publicado en el diario El Día de La Plata, se solicitaron CV y pretensiones para cubrir los siguientes perfiles:

\section{Perfil para personal de contacto:}

Sexo: femenino.

Edad: ideal 25 a 35 años.

Estudios: ingeniería civil, arquitectura o decoración.

Conocimientos: mínimos de computación.

Capacidades:

- Buena imaginación.

- Capacidad de diseño.

- Alta capacidad dialéctica.

- Buena adaptabilidad para asumir roles y convertirse en espejo.

Roles esperados: convertirse en compañera de compra del cliente.

\section{Perfil para personal de ventas:}

Sexo: masculino.

Edad: ideal 25 a 35 años.

Estudios: ingeniería civil o arquitectura.

Conocimientos: computación manejo de programas de diseño gráfico.

Movilidad propia: si

Capacidades:

- Buena imaginación.

- Capacidad de diseño. 
- Alta capacidad de comprensión.

- Buena adaptabilidad para captar problemas y suministrar soluciones.

Roles esperados:

- Convertirse en jefe de compras del cliente.

- Mejorar la relación costo / beneficio esperada por el cliente.

Luego de la evaluación y selección de los entrevistados, el nuevo personal, participó de un entrenamiento para la gestión de ventas.

\subsection{Guía metodológica para exposiciones.}

Se ha trabajado desde distintos enfoques que involucran a las actividades comerciales necesarias para revertir la situación actual analizada y conseguir recuperar las cuotas de mercado que poseían en otros tiempos.

Parte de estas actividades comerciales pasan, obviamente, por una revisión detallada de los aspectos de marca e imagen necesarios, y por establecer pautas comerciales y de transmisión de información que se adecuen y satisfagan las necesidades del público actual.

Así mismo, es necesario reforzar la presencia de La Española en eventos y actividades que permitan mostrar a su público los avances tanto en materia de diseño como de tecnología aplicada, así como las ventajas diferenciales que ofrece el mosaico en la construcción.

Por esto, a continuación reflejamos algunos aspectos importantes a tener en cuenta en las decisiones de participar en ferias y exposiciones. Así mismo, se resumieron los aspectos principales de cada tipo, de forma que este documento se convierta en una guía para exposiciones que pueda ser tenida en cuenta por La Española en los eventos en los que pretenda participar en el futuro. 
Inicialmente, se consideró apropiado resumir algunos conceptos importantes en cuanto a tipos y características de los eventos comerciales referidos: ferias y exposiciones.

Las ferias y exposiciones actuales, pueden clasificarse en:

- Horizontales o generales.

- Verticales.

- Especializadas o temáticas.

- Itinerantes.

\section{Ferias horizontales o generales:}

En estas, se exhiben una gran variedad de productos de diferentes industrias, existiendo además, la posibilidad de vender de los mismos al público asistente.

En general no existe interés específico por parte de los visitantes por un producto en particular, logrando mayores beneficios aquellos stands que exhiban productos ya conocidos o posicionados en la mente de los concurrentes por algún atributo de los mismos.

\section{Ferias verticales:}

Hablamos aquí de los productos de mayor especialización que los presentados en las ferias horizontales. Su objetivo principal es que nuestros potenciales clientes puedan examinar el producto que esté directamente relacionado con su actividad.

Estas se caracterizan por la exposición de todos los elementos que formarán el producto final; vale decir que este tipo de eventos nos permite visualizar cuales son y como se fabrican los componentes del producto terminado. Por ejemplo si se trata de artículos del calzado se expondrá como se curte el cuero, el hilo utilizado para su costura, el tipo de suela a emplear, la tintura de acabado final, tipos de cordones, etc.

\section{Ferias especializadas o temáticas:}

Estas exposiciones se caracterizan por mostrar y tratar asuntos específicos, las cuales se comparten entre personas de un rubro determinado. 
Aquí existe una fehaciente y potencial posibilidad de concretar negocios, puesto que las personas que asisten a la exposición lo hacen con un fin netamente comercial.

Tanto las misiones comerciales como las exposiciones no logran asegurar el éxito de la inserción del producto en el mercado potencial, pero generan contactos con especialistas en la materia, de los cuales se logra obtener información muy valiosa.

\section{Itinerantes:}

Pueden definirse, como exposición exclusiva, que prepara el futuro exportador sobre sus ofertas. De esta manera, su objetivo es visitar a los potenciales clientes en forma directa y presentarles los atributos de sus productos.

Se destinan exclusivamente a compradores mayoristas y en ellas se exhibe, por lo general, un solo producto por rubro.

\section{Antes de participar en una feria o exposición:}

El éxito no debería ser una cuestión de azar, es decir que a mayor esfuerzo es posible que mayor cantidad de clientes visiten el stand.

Se deberían seleccionar aquellas ferias o exposiciones en las cuales nuestros productos resulten competitivos.

Definir donde hemos de participar:

- Pabellones nacionales.

- Pabellones comerciales.

- En forma individual.

\section{Solicitar datos sobre:}

- Cantidad de personas que visitaron los stands años anteriores.

- Niveles de venta obtenidos en el rubro que nos interesa.

- Calidad de los expositores, etc. 
Identificar a la audiencia que queremos alcanzar, para luego saber a quién dirigir nuestros esfuerzos.

Decidida la participación, se debería asistir a la muestra que se realiza un año antes al de nuestra participación con el fin de:

- Conocer tendencias.

- Formas de exponer.

- Espacios disponibles.

- Visibilidad.

- Competidores principales.

- Aspecto general de la muestra.

- Nivel de asistentes.

Se debe conocer al detalle que servicios brindarán los organizadores; es decir como estará compuesto el stand de La Española (a modo de ejemplo).

\section{Estructura base del stand:}

Es importante conocer detalladamente que elementos van a estar incluidos o no en la oferta del organizador del evento. Este aspecto debe ser revisado con mucha precisión para evitar sorpresas o malentendidos y sobre todo, para poder esbozar una idea previa precisa sobre la inversión necesaria.

\section{Stand completo incluye ${ }^{22}$}

- Alfombra

- Pared posterior y divisoria, de $2.5 \mathrm{~m}$ de altura con mamparas y estructuras de aluminio.

- Aparatos de iluminación: por $\mathrm{m}^{2}$.

- Rótulo señalando el nombre de la empresa expositora.

- Invitaciones generales a la exposición 5 por cada $\mathrm{m}^{2}$ adquirido.

\footnotetext{
${ }^{22}$ Estos aspectos son únicamente una referencia de que elementos son incluidos normalmente en la organización de eventos. Es posible que algunos organizadores ofrezcan más o menos elementos de los aquí expuestos en su oferta de participación en eventos. El objetivo de este punto es únicamente ofrecer una idea aproximada de los elementos a tener en cuenta en el proceso.
} 
- Toma de corriente (uno).

- Escritorio (uno), sillas (dos).

\section{Stand completo no incluye:}

- Suministro de energía eléctrica.

- Pases de estacionamiento

\section{Forma de invitar a su audiencia objetivo:}

Existen muchas formas de atraer al evento a la audiencia objetivo que queremos que asista. A continuación resumimos sólo algunas de las más habitualmente utilizadas para el rubro:

- Publicite en revistas del mercado.

- Publicite en el avance y catálogo de expositores. Es común que, los visitantes lleguen a la feria o exposición con una agenda de visitas a expositores. Por sería interesante que nuestro stand esté dentro esa agenda.

- El catálogo de expositores es una pieza que contiene toda la información sobre los expositores, que tipos de productos y servicios se ofrecen, su ubicación dentro del pabellón, sus contactos comerciales y demás datos de interés. Además contiene los ciclos de conferencias y congresos que se realizarán. Este es distribuido entre todos los asistentes a la exposición, a las oficinas gubernamentales, asociaciones comerciales y cámaras de comercio. Es por ello que es muy importante que su empresa figure en dicho catálogo.

- Difunda el número de stand en donde pueden visitarlo.

- Curse cartas, llamados telefónicos o e-mail dos semanas antes de la exposición e incluya invitaciones VIP para su stand.

- La correspondencia se destinará a nombre de la persona que puede decidir la compra.

Las direcciones de nuestros clientes potenciales, se pueden obtener de:

- Cámaras y asociaciones empresarias.

- Páginas amarillas de la guía telefónica.

- Direcciones suministradas por nuestro agente o representante. 


\section{Durante la feria o exposición:}

A continuación resumimos algunos aspectos importantes a tener en cuenta durante el desarrollo del evento:

- Obtener una buena base de datos de las personas que visitaron nuestro stand es muy importante para concretar o cerrar negocios pendientes o futuros.

- Es por ello que existen distintas empresas que ofrecen este servicio de captura de datos de los visitantes, usándose por lo general códigos de barras con registrador de datos.

- Independientemente de esto, es recomendable que La Española mantenga su propia base de datos, y permita el registro de cada visitante al stand. Para esto, a continuación presentamos un modelo de planilla de registro y seguimiento de visitas, para ser usada como modelo. En función de cada exposición y del perfil de la audiencia en cada caso, habrá que revisar y rediseñar el modelo final adecuado de planilla.

- Los encargados de cada stand serán los responsables de dar respuestas a todo tipo de interrogantes que surjan por parte de los visitantes. Es por ello que al seleccionar la persona que nos representará deberá tenerse en cuenta que posea un correcto conocimiento del producto, su fabricación y utilización, así como tener poder de decisión para cerrar operaciones comerciales.

- Es importante trabajar con una estructura piramidal donde las promotoras se encargan de distribuir los catálogos y atraer a interesados los que pasan al segundo nivel donde los atiende personal especializado en el tema, recibiendo muestras y folletería especifica del producto solicitado, para en algunos casos pasar a personal de tercer nivel el cual trata el cierre de negocios específicos.

\section{Después de la feria o exposición:}

A continuación resumimos algunos aspectos importantes a tener en cuenta después del desarrollo del evento.

El último día de la muestra se ordenará y clasificará toda la información recogida. Tratando de: 
- Cerrar contratos.

- Formalizar acuerdos.

- Efectivizar ventas.

Finalmente dentro de la primer semana de finalizada la exposición es importante resolver los temas pendientes así como los compromisos asumidos con los potenciales clientes.

\section{Aspectos generales de la participación:}

Es relevante organizar la exposición, en el lugar y la fecha que considere más conveniente. Se puede realizar individualmente o en conjunto con otras empresas competidoras o complementarias.

Cabe destacar que el nivel de éxito alcanzado en este tipo de eventos dependerá pura y exclusivamente de cuanto y como nos hemos movilizado con anterioridad al evento, hacia nuestro mercado objetivo, ya sea por medios de comunicación masiva, revistas del rubro, e-mails u otro posible tipo de contactos que se realizan con la anterioridad suficiente para que el día del evento se recojan frutos y no gastos.

\section{Costos de la participación en una feria o exposición:}

Aquí se mencionan los principales rubros a tener en cuenta para conformar el costo total de exposición:

- Alquiler del espacio físico $\left(\mathrm{en}^{2}\right)$.

- Construcción y montaje del stand.

- Decoración, iluminación, alfombras y equipos de distribución.

- Remuneraciones a recepcionistas e intérpretes.

- Transporte y seguro de los artículos a exponer.

- Transportes (ida y vuelta) y seguros locales.

- Embalaje y transporte de las mercaderías (al fin de la exposición).

- Gastos de limpieza, electricidad y vigilancia, etc., del stand.

- Comisiones e impuestos.

- Seguros diversos. 
- Agasajos (refrigerios, cocktails, cenas, etc.).

- Circulares folletos, literatura impresa para su distribución gratuita.

- Atenciones, muestra gratis, etc.

- Publicidad directa y la compartida con la organización de la exposición.

- Viajes y estadía de los responsables de la empresa, lo que incluirá los gastos posteriores a la muestra.

- Gastos extraordinarios e inesperados.

Es muy importante no olvidar ninguno de estos aspectos clave para obtener el máximo beneficio de este tipo de eventos tan importantes y extendidos en la actualidad.

Seguidamente, se puede observar el modelo de stand propuesto.

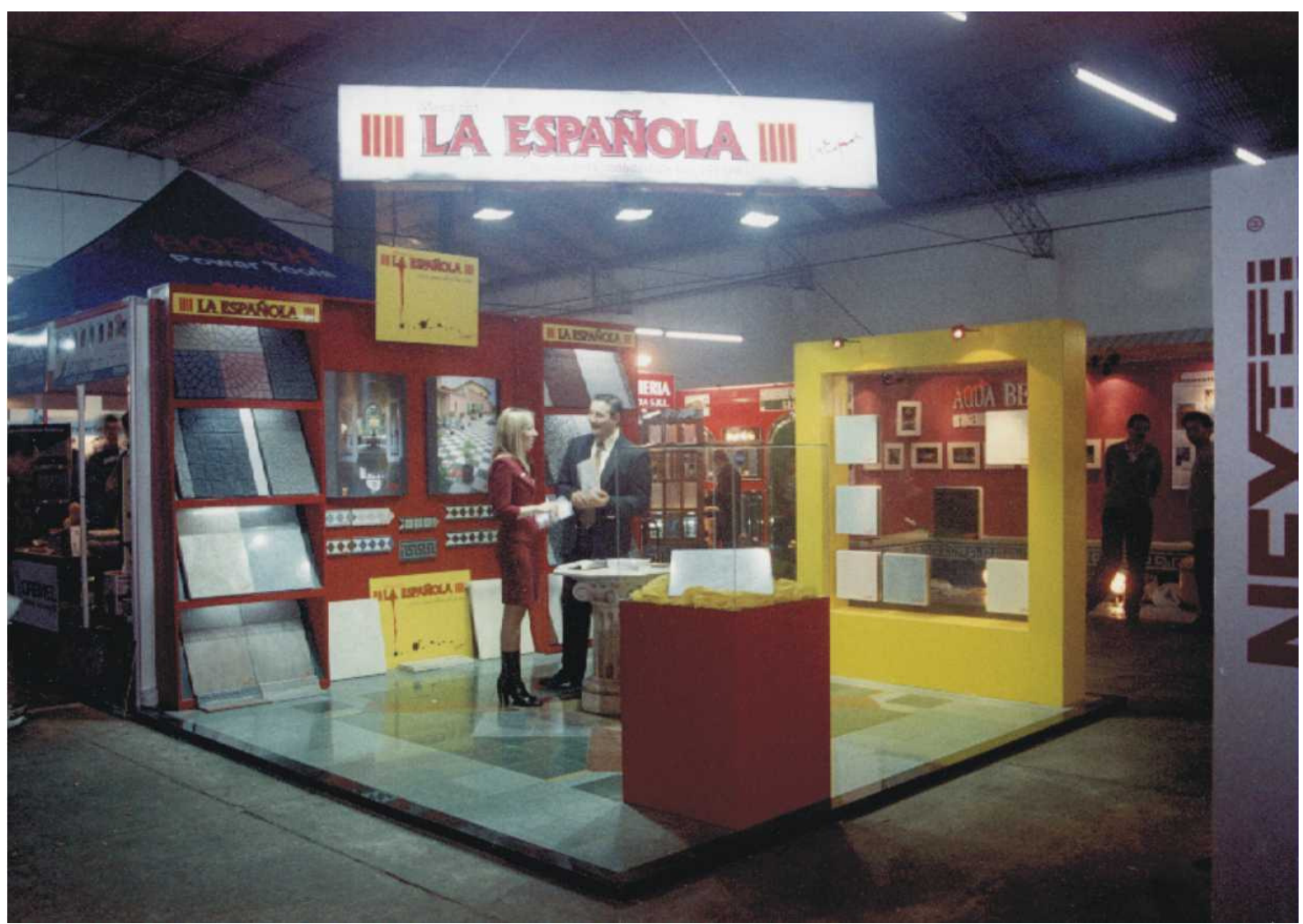




\section{MEDICIÓN DEL IMPACTO.}

\subsection{Evaluación y análisis de resultados.}

En el análisis inicial la empresa abastecía a un 30\% del mercado, que después con la implementación del Plan de Marketing, pasó a controlar el precio del mercado con el $55 \%$ del mercado total.

De las cinco empresas que abastecían al mercado local, La Española se ubicaba en el $3^{\circ}$ puesto en ventas. Hoy, una de las empresas ya no está más en el mercado y La Española absorbió a otro de sus competidores.

Entre sus dos actuales competidores, se encuentran: la firma Canalini, y la Di Domenicantonio, con la que comparte un pacto de no-agresión.

La Española, pasó de un balance de facturación mensual promedio de \$/USS 100.000 con una pérdida mensual de \$/U\$ 1.000-2.000; a una facturación de \$/U\$S 130.000 con una utilidad de \$/USS 7.000 mensuales. Esta utilidad permitió comprar el activo tecnológico de uno de sus competidores.

Hasta octubre del 2001 se mantuvo con ventas, en diciembre vendió 0 (cero), en enero de este año $\$ 40.000$, en febrero $\$ 50.000$, y gracias a la salud en que se encontraba, pudo subsistir hasta hoy.

La cotización actual de la divisa norteamericana, está permitiendo estudiar una exportación a USA, ya que con la diferencia que existe entre el valor del mosaico en el mercado norteamericano (22 $\left.\mathrm{U} \$ \mathrm{~S} / \mathrm{m}^{2}\right)$ y el valor en Argentina $\left(10 \$ / \mathrm{m}^{2}\right)$, se pueden absorber los gastos de logística necesarios para arribar a este nuevo mercado.

Además, aprovechando este beneficio cambiario la firma se está expandiendo en Brasil, asociada a empresarios brasileros. 
Cronograma de la Metodología

\section{Actividades}

A. Conceptualización del Problema.

A.1. Detección de Oportunidades.

A.2. Definición de Objetivos-Meta.

A.2. Planeamiento de Marketing Estratégico.

B. Análisis Particularizado de:

B.1. Situación de la Empresa.

B.2. Mercado de la Construcción

B.3. Sector Específico.

B.4. Competencia.

D. Propuestas y Evaluación de Soluciones.

D.1. Imagen Institucional.

D.2. Nuevos Diseños de Mosaicos.

D.3. Puntos de Venta.

D.4. Control de Gestión.

E. Implementación del Plan de Marketing.

F. Medición del Impacto Obtenido en el Sector.

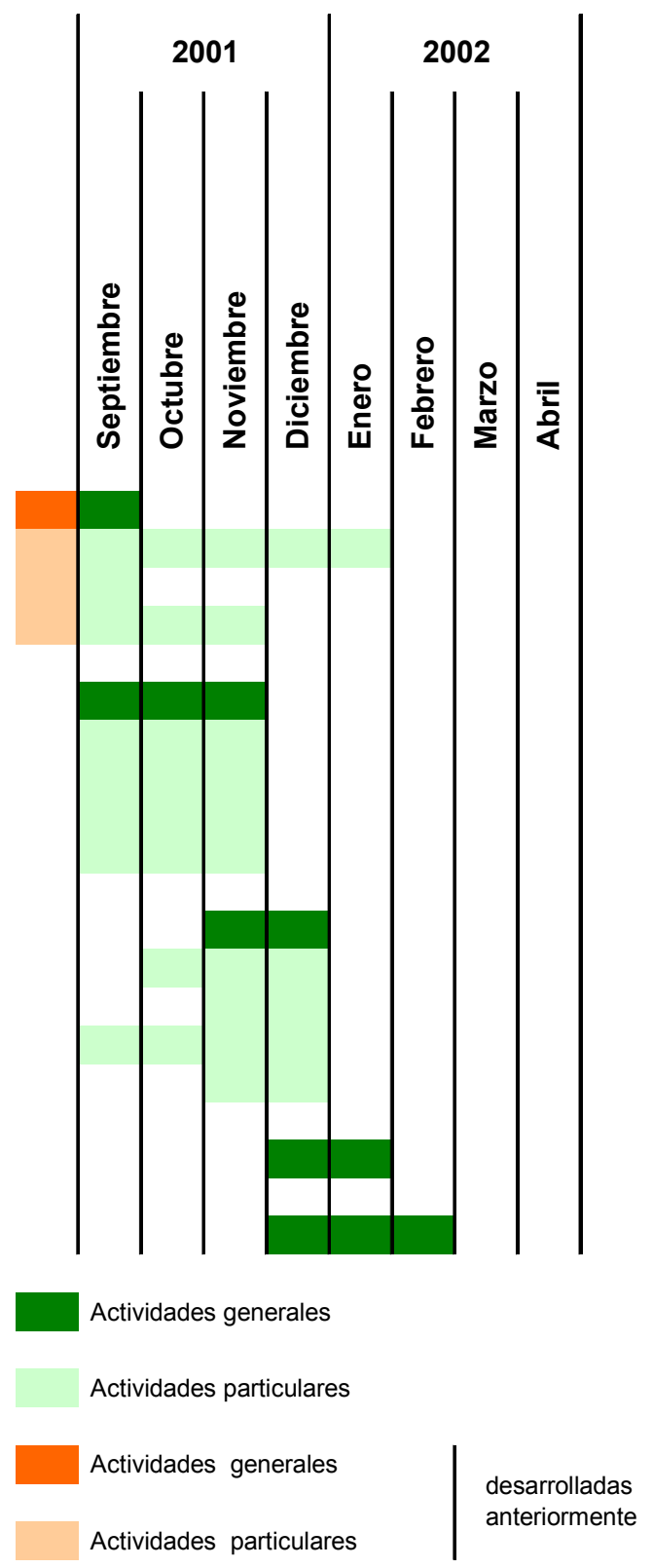




\begin{tabular}{|c|c|c|c|c|c|c|c|c|c|c|c|c|}
\hline \multirow{6}{*}{ ర্ঠ } & oḷune & & & & & LLt & & & & & $000^{\circ} z$ & டレナて \\
\hline & oKeW & & & & SL9 & $\angle L t$ & & & & & $000^{\circ} z$ & $260^{\circ} \varepsilon$ \\
\hline & I! & & & & $\mathcal{G L 9}$ & $L L t$ & & & & & $000^{\circ} z$ & $Z 60^{\circ} \varepsilon$ \\
\hline & ozıew & & & & & $\angle L t$ & & & & & & $\angle 1$ \\
\hline & $0\lrcorner \partial \lambda q \partial$ & & & & & $L t t$ & & & & & & $\angle 1$ \\
\hline & оләиэ & & & & & $L l t$ & 009 & & & $00 \mathrm{~S}$ & & LLt \\
\hline \multirow{6}{*}{ 옹 } & әлquә!ฺ! & 092 & & & & $\angle L t$ & $00 \mathrm{~S}$ & & $00 \mathrm{~S}$ & $00 \mathrm{~S}$ & & $\angle 9 l$ \\
\hline & ә.дquə!ıON & 092 & & & & $L L t$ & & জてદ & 009 & & & $26 t$ \\
\hline & әرqnґ०O & 092 & & & & $\angle L t$ & & GZ\& & & & & 26 \\
\hline & әлquә!्dәS & $09 Z$ & $299^{\prime} \mathrm{L}$ & & & $L L t$ & & & & & & દદย'乙 \\
\hline & 0.506 $\forall$ & 092 & $\angle 99^{\circ} \mathrm{L}$ & $00 \mathrm{~S}$ & & $L l t$ & & & & & & દ£8 \\
\hline & o!!ne & $09 Z$ & $299^{\circ} \mathrm{L}$ & 009 & & Lbt & & & & & & ¿हర \\
\hline
\end{tabular}

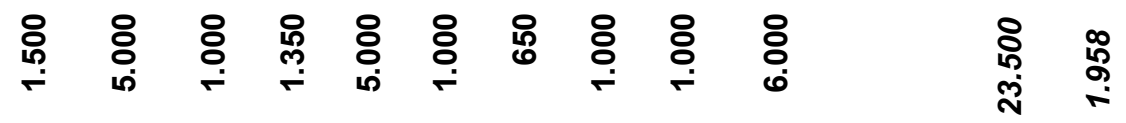

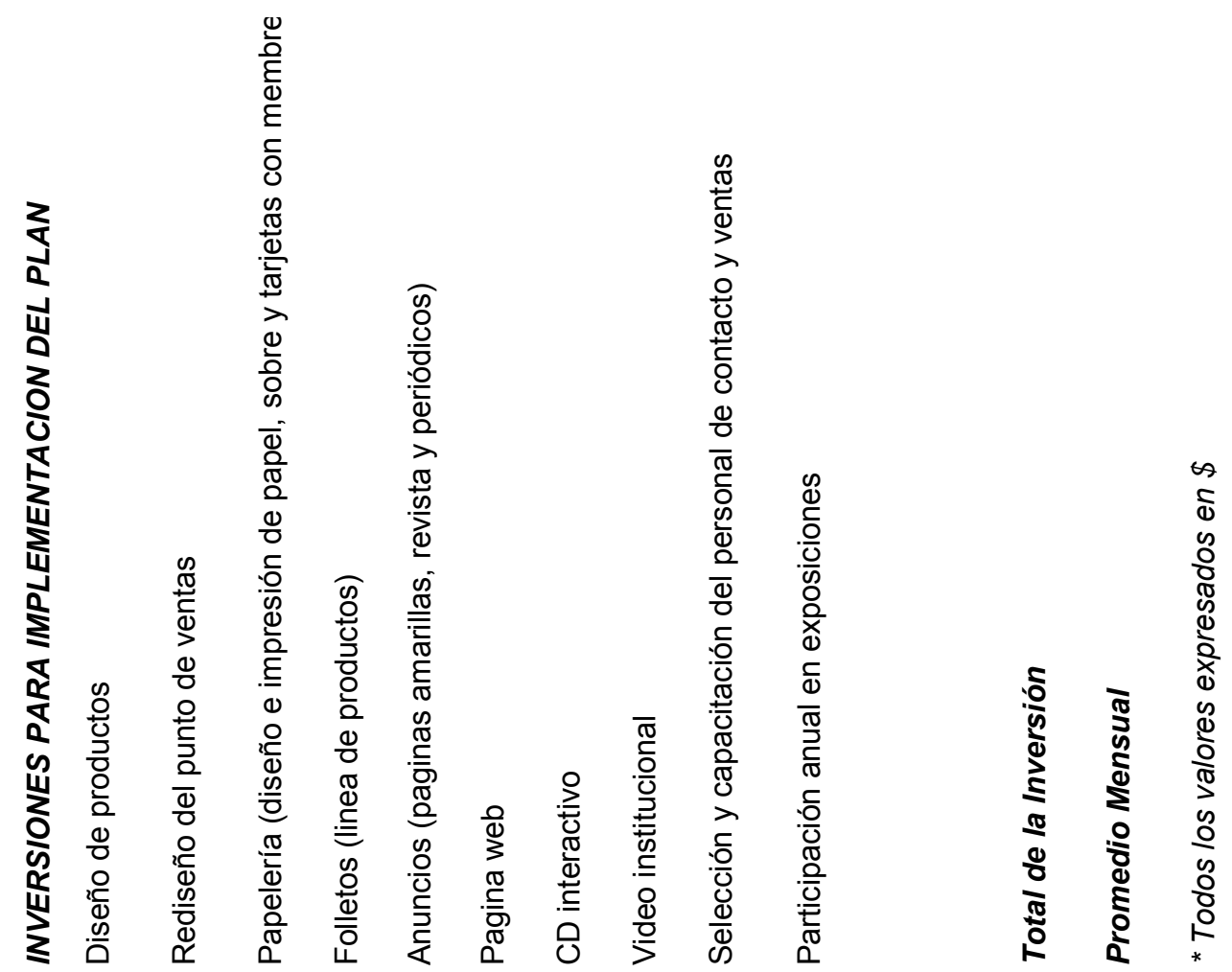


6.

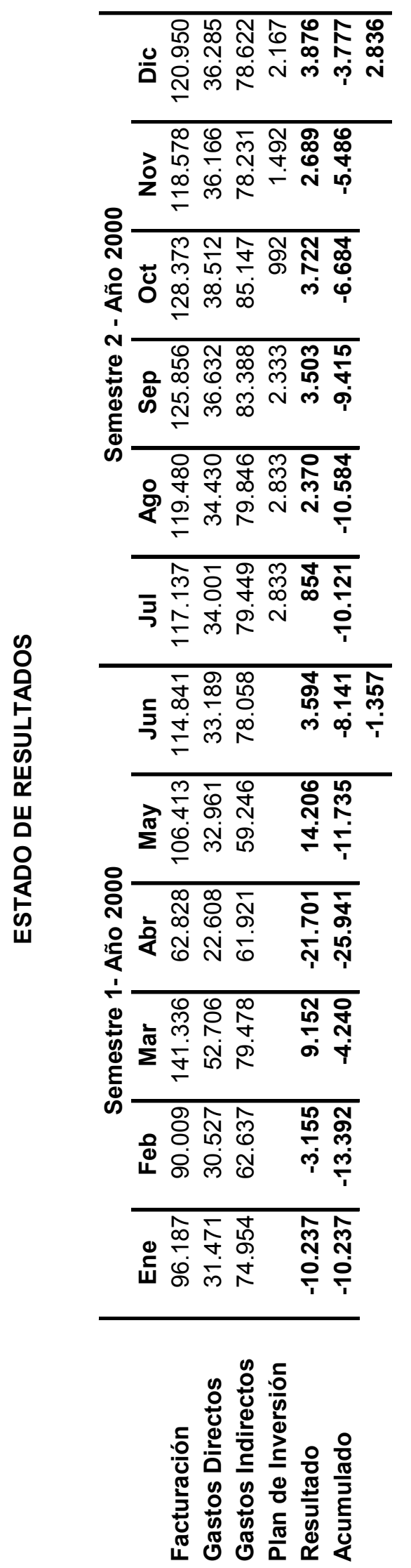

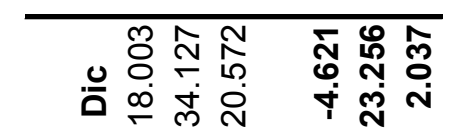

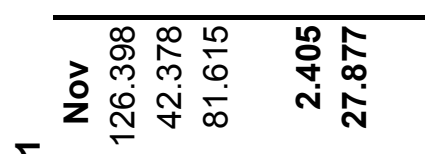

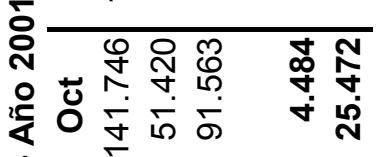

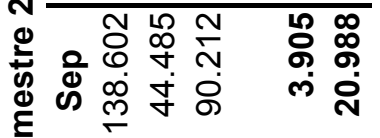

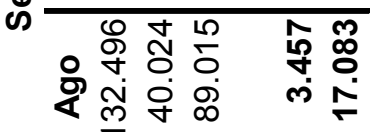

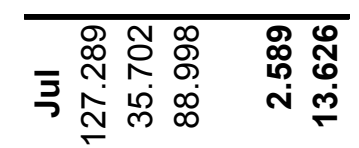

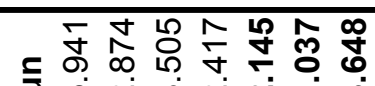

产 守

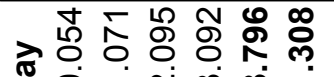

एँ

ণั่

它守 穴

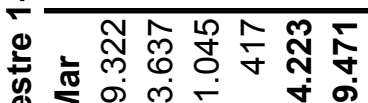

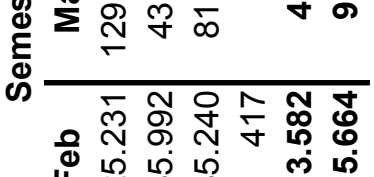

迹占

$\infty$
0
0
0
0
0
0
0
0
0
0
0
0
0
0
$\frac{0}{80}$
0
0
08
0
0
0
$*$ 


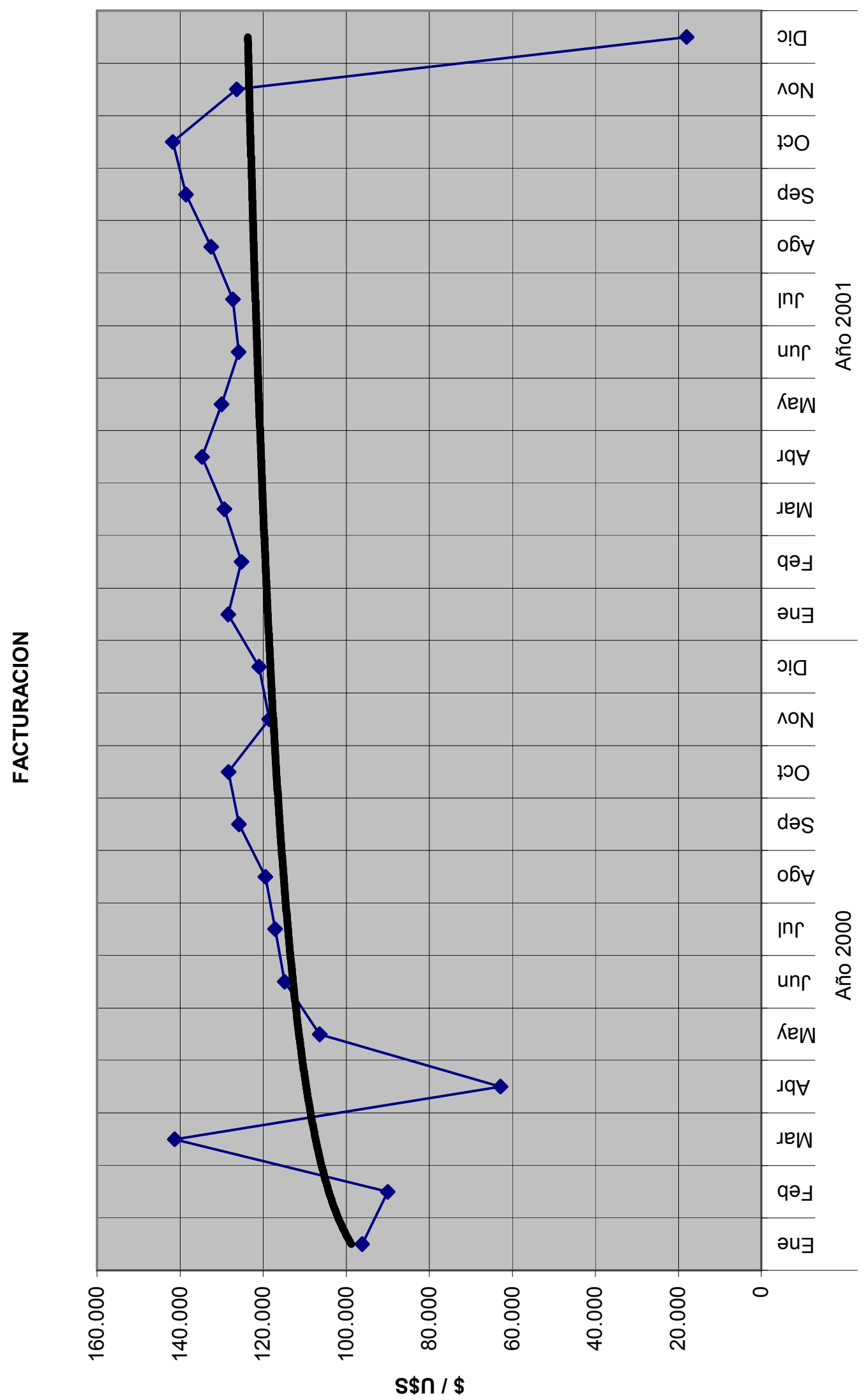




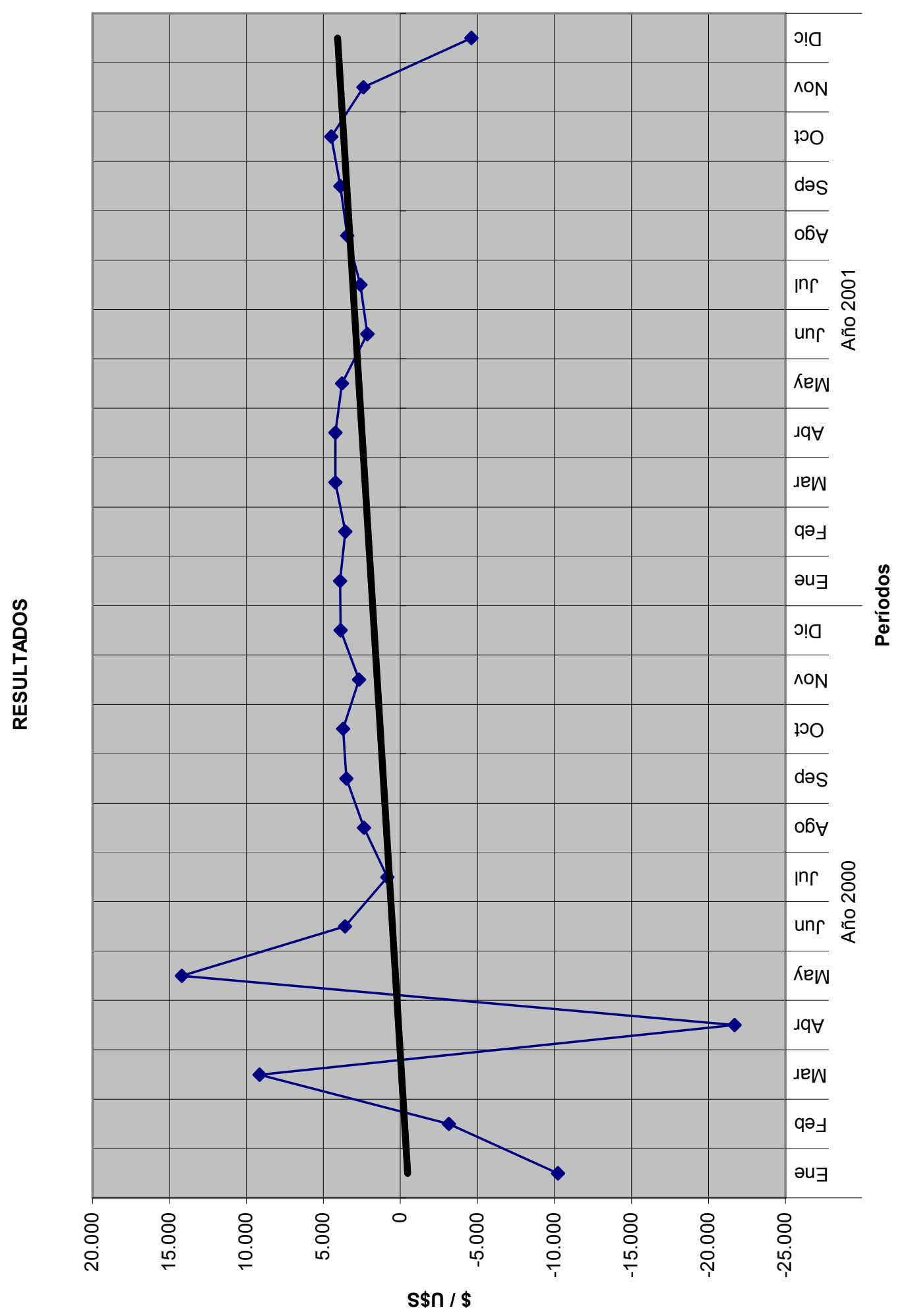




\section{CONCLUSIONES.}

La tarea emprendida, estuvo principalmente ligada al desarrollo de un Plan de Marketing Estratégico para la empresa La Española.

En una primera fase se realizó una investigación de empresa, de estrategia comercial y de productos. Esto mostró una buena situación de la compañía en lo referente a la calidad de sus productos y al reconocimiento de la marca.

El análisis pormenorizado de los puntos fuertes y débiles, evidenció las áreas en las cuales la empresa debía mejorar su situación actual.

En el análisis del mercado y su segmentación, se realizó un estudio de las fortalezas y debilidades del sector y de la competencia.

Estudiadas las posibilidades potenciales de la empresa, se desarrollaron e implementaron distintas actividades estratégicas de imagen institucional, a través de un nuevo eslogan de marca direccionado al mercado objetivo.

La generación de nuevas líneas comerciales y el diseño de los nuevos mosaicos, conformaron junto al rediseño del punto de venta, la principal estrategia comercial de La Española.

También, con este nuevo concepto, se desarrolló la papelería, los folletos y avisos publicitarios, un CD interactivo y un video institucional.

También se realizó un asesoramiento para la selección del personal de contacto y de ventas, y se confeccionó una guía metodológica para exposiciones.

Para la medición del impacto se estudió el presupuesto y se evaluaron los resultados obtenidos, leyéndose así el éxito del Plan de Marketing implementado. 
Fundamentado por el liderazgo alcanzado en el mercado, se puede afirmar, que este trabajo ha contribuido con Mosaicos La Española.

La Plata, Abril de 2002.

Federico Del Giorgio Solfa 


\section{BIBLIOGRAFÍA.}

Albrecht, Donna G., Promoting your Business With Free Publicity, Prentice Hall, New Jersey 1997.

ARIAS, JuAn, Maestros del Diseño Español, identidad y diversidad, Experimenta, Madrid 1996.

Bonsiepe, Gui, Teoría y Práctica del Diseño Industrial, elementos para una manualística crítica, Gili, Barcelona 1978.

BONSIEPE, Gui, Del Objeto a la Interfase, mutaciones del diseño, Infinito, Buenos Aires 1999.

Bransford, JHOn D.- STEIN, BARRY S., Solución Ideal de Problemas, guía para mejor pensar, aprender y crear, Labor, Barcelona 1986.

Buch, TomÁs, Sistemas Tecnológicos, contribuciones a una teoría general de la artificialidad, Aique, Buenos Aires 1999.

BÜrdek, Bernhard E., Diseño: Historia, teoría y práctica del diseño industrial, Gili, Barcelona 1994.

Campana, Enzo - Gómez SÁnchez, Francisco J., Principios de Mercadotecnia, Editorial Universitaria de La Plata, La Plata 2000.

Donato, Vicente N., La Evolución Territorial-Sectorial de las PyMEs Argentinas (1994-2000), Observatorio Permanente de las PyMIs Argentinas y la Università degli Studi di Bologna - Sede Buenos Aires, Instituto para el Desarrollo Industrial de la Unión Industrial Argentina, Buenos Aires 2001.

Donato, Vicente N., Evolución y Situación Actual de las Pequeñas y Medianas Industrias Argentinas 1995-2000, Observatorio Permanente de las PyMIs Argentinas y la Università degli Studi di Bologna - Sede Buenos Aires, Instituto para el Desarrollo Industrial de la Unión Industrial Argentina, Buenos Aires 2001.

Eco, Umberto, Come si fa una Tesi di Laurea. Le materie umanistiche, Bompiani, Milano 1981 ( $11^{\circ}$ edizione di 2000).

Frasser-Robinson, John, El Marketing de Calidad Total, Deusto, Buenos Aires 1993.

Goldratt, Eliyahu M., La Meta, Castillo, Monterrey 1993.

Goldratt, EliYAhu M., No Fue La Suerte, Castillo, Monterrey 1994.

HANAN, MACK, Estrategias Recompetitivas, Norma, Bogotá 1987. 
Karofsky, Paul I., Cómo Sobrevivir en una Empresa Familiar (Material del Seminario), Small Business Management Program, Northeastern University, Boston 1999.

Levy, Alberto R. - Wilensky, Alberto L., Cómo hacen los que hacen, Tesis, Buenos Aires 1987.

Levy, Alberto R., El Cómo y El Porqué, un camino hacia el desarrollo empresario, Norma, Buenos Aires 1989.

Levy, AlBerto R., Mayonesa, la esencia del marketing, Granica, Buenos Aires 1998.

Maldonado, Tomás, Disegno Industriale: un riesame, Feltrinelli, Milano 1976. (edizione riveduta e ampliata 2001).

MANZINI, EzIO, Artefatti. Verso una nuova ecología dell'ambiente artificiale, Domus Academy, Milano 1990.

Morace, Francesco, Contratendencias, una nueva cultura del consumo, Celeste y Experimenta, Madrid 1993.

Munari, Bruno, Da Cosa Nasce Cosa; appunti per una metodología progettuale, Economica Laterza, Bari 1981.

Munari, Bruno, Design e Comunicazione Visiva, Economica Laterza, Bari 1981.

O'Hara, PAtrick D., El Plan Empresarial Integral: cómo prepararlo, redactarlo y revisarlo, Deusto, Buenos Aires 1993.

Pope, JefFrey L., Investigación de Mercados, Norma, Bogotá 1997.

Revista ARTe e InVestigación, Año 3 № 3, Revista Científica de la Facultad de Bellas Artes, Universidad Nacional de La Plata.

Revista Arte e InVestigación, Año 4 No 4, Revista Científica de la Facultad de Bellas Artes, Universidad Nacional de La Plata.

Revista Gestión, Vol. 2 № 4 de Julio-Agosto de 1997, Buenos Aires Review.

Revista Gestión, Vol. 2 No 5 de Septiembre-Octubre de 1997, Buenos Aires Review.

SallenaVe, JeAn-PAUl, La Gerencia Integral, Norma, Bogotá 1994.

Smith, AdAm, La Riqueza de las Naciones (1776), Edición de Carlos Rodríguez Braun, Alianza, Madrid 1997.

WeIss, W. H., Guía Práctica para la Toma de Decisiones, Norma, Bogotá 1987. 


\section{Aclaración:}

Yo aseguro que esta Tesis fue elaborada por mí, que no utilicé ningún otro material que no haya dado a conocer en las referencias y que no utilicé frases o párrafo de otros autores, que este trabajo de Tesis nunca ha sido presentado ante un Comité de Evaluación de Tesis y que no transgredí derechos de terceros. 


\section{UNIVERSIDAD NACIONAL DE LA PLATA}

Facultad de Ciencias Económicas

Escuela de Postgrado de Marketing Internacional

Magíster en Marketing Internacional 